OECDpublishing

\title{
TRADE AND GENDER
}

A FRAMEWORK OF ANALYSIS

OECD TRADE POLICY PAPER

March $2021 \quad \mathbf{n}^{\circ} \mathbf{2 4 6}$ 


\title{
OECD TRADE AND AGRICULTURE DIRECTORATE
}

\section{Trade and Gender: A Framework of Analysis}

\author{
Jane Korinek, Evdokia Moïsé, Jakob Tange
}

\begin{abstract}
Closing gender gaps makes good economic sense. Advancing the aim of women's economic empowerment will require policy action across a wide range of areas, including increasing their participation in international trade. Although trade policies are not de jure discriminatory, they impact women and men differently due to dissimilar initial conditions. Mapping the channels and interactions between trade and gender for women as workers, consumers, and business owners shows that: (i) trade impacts women workers differently to men in part because they are employed in different sectors - in OECD countries, more often in services; (ii) trade lowers prices for consumers, which particularly increases the purchasing power of more vulnerable groups, where women are disproportionately represented; and (iii) higher trade costs impede smaller businesses' access to international markets more than large firms, which impacts women who tend to own and lead smaller businesses. A framework is proposed for analysing the impacts of trade and trade policies on women that policy makers can use in order to ensure that trade and trade policies in their country support women's economic empowerment.
\end{abstract}

Key words: Gender equality, preferential trade agreements, trade facilitation, women entrepreneurs, gender impact analysis

JEL codes: F13, F66, J16

\section{Acknowledgements}

This paper was prepared by Jane Korinek, Evdokia Moïsé, and Jakob Tange of the OECD Trade and Agriculture Directorate. The authors are grateful for the guidance received from Susan Stone, Julia Nielson, and Marion Jansen of OECD Trade and Agriculture Directorate. The research benefitted from many substantive comments from OECD and Observer Delegations to the Working Party of the Trade Committee. Comments were also gratefully received from Roberta Piermartini, José-Antonio Monteiro, and Victor Stolzenburg of the World Trade Organisation (WTO). Valuable input was provided by colleagues from OECD Trade and Agriculture, Statistics and Data, and Science, Technology and Innovation Directorates during an expert meeting; and from a meeting with the gender team at ProChile, the Chilean export promotion agency, and trade experts from the Chilean Under-secretariat of International Economic Relations. Clarisse Legendre provided statistical assistance. 


\section{Table of Contents}

Executive Summary $\quad 3$

Key findings $\quad 3$

$\begin{array}{ll}\text { 1. Introduction } & 7\end{array}$

$\begin{array}{lr}\text { 2. Women workers } & 10\end{array}$

$\begin{array}{lr}3 . \text { Women consumers } & 21\end{array}$

4. Women entrepreneurs and business owners $\quad 27$

5. Gender in Preferential Trade Agreements 39

6. An analytical framework for assessing and improving the gender responsiveness of trade
policies

$\begin{array}{lr}\text { References } & 60\end{array}$

Annex A. Women in export-supported employment 68

Annex B. Comparative tariff rates on feminine sanitary products and diapers 70

Annex C. Characteristics of women-owned firms and the barriers women face to entrepreneurship 71

Annex D. Linking data sources for gender-differentiated trade analysis: The case of Finland 78

Annex E. Domestic policy areas that most impact women's ability to benefit from trade 80

Annex F. A checklist for assessing and improving the gender responsiveness of trade policies 81

\section{FIGURES}

Figure 1. Trade and gender: An illustrative representation of interactions $\quad 10$

Figure 2. Shares of employment depending on foreign final demand by gender 12

Figure 3. Shares of employment in direct and indirect exports by gender $\quad 13$

Figure 4. Employment by gender meeting domestic and foreign final demand, $2015 \quad 14$

$\begin{array}{lll}\text { Figure 5. } & \text { Gender wage gap, employees } & 17\end{array}$

Figure 6. Expenditure per category as a share of total income in France and Spain 24

Figure 7. No gender discrimination found in import tariffs $\quad 26$

Figure 8. $\quad$ Import tariffs on sanitary napkins, tampons and diapers 26

Figure 9. Share of firms with a Facebook presence that trade by gender 30

$\begin{array}{lll}\text { Figure 10. Share of firms that trade by size and sector } & 31\end{array}$

Figure 11. Number of destination countries by size of exporting firm $\quad 32$

Figure 12. Main challenges faced by businesses that export $\quad 33$

Figure 13. Share of home-country orders received through e-commerce 36

Figure C.1. Firm size by gender of owner/manager $\quad 72$

$\begin{array}{lll}\text { Figure C.2. Women led firms are concentrated in services sectors } & 73\end{array}$

$\begin{array}{lll}\text { Figure C.3. } & \text { Motivations to pursue entrepreneurship } & 74\end{array}$

\section{TABLES}

Table A.1. Share of women in employment and in export-supported employment 68

Table A.2. Share of women in employment and in export-supported employment by broad sectors $\quad 69$

Table B 1. Tariffs on feminine hygiene products and diapers $\quad 70$ 


\section{Executive Summary}

Although women now outpace men in educational attainment and have made great strides toward equal rights, gender gaps persist in OECD countries. At the present rate of change, achieving global economic gender parity will take 257 years (World Economic Forum, 2019). Clearly, there is a large role for policy to advance the aim of women's economic empowerment in a more timely manner. Although domestic policy areas have been rightly prioritized in advancing women's economic empowerment, trade and trade policy may also have a role to play.

By providing a framework for analysis of how trade and trade policies impact women and men differently, and the barriers women face engaging in international trade, this paper aims to assist governments in their design of trade provisions, trade policies, and their implementation that will help enable the benefits of trade to be more widely shared. It analyses the channels and interactions between trade and gender along three of the economic roles played by women in trade: as workers, as consumers, and as entrepreneurs and business owners. It also considers the role of preferential trade agreements in advancing women's economic empowerment.

\section{Key findings}

\section{The impacts of trade on women as workers, consumers and entrepreneurs}

Women as workers: The number of women working in export-dependent sectors in OECD countries has increased in the past decade, although at a slower rate than men's participation. Women's participation in export-dependent jobs ${ }^{1}$ is considerably higher when taking account of women working indirectly in trade, i.e. working in sectors that serve as inputs into goods and services that are exported. However, women are still underrepresented in indirect exports compared to men. Women work less in trade-dependent jobs because they tend to work in less export-oriented sectors, notably in services. Even within services sectors, women hold the majority of jobs in the less traded sub-sectors such as education, health, public administration and personal services.

While wages are higher for both men and women in exporting firms, the gender wage gap persists in these firms in OECD economies. Increased competition through trade reduces the ability of local employers to incur the additional costs that result from discriminating between men and women; in this way, trade can lead to less gender discrimination. However, in some OECD countries a larger gender wage gap has been found in exporting firms as compared with those that engage only in the domestic market, especially among highly skilled individuals. One study suggests that one reason for this could be that flexible working hours are important in exporting firms and women are perceived to be less flexible in their working hours.

Women as consumers: Recent evidence indicates that there is no gender discrimination in import tariffs on goods that can be differentiated on the basis of gender, mainly apparel, in OECD countries. Moreover, evidence suggests that the gains from trade for consumers can be substantial by lowering prices and by increasing consumers' purchasing power. Lower income households, in which women are disproportionately represented, benefit even more from these lower prices than higher income households because a greater share of their disposable income is spent, including on traded consumer goods. Removing barriers to trade in order to decrease prices and increase the variety of products available to households therefore positively impacts lower-income households, where women are more prevalent, in

\footnotetext{
${ }^{1}$ Export-dependent or export supported jobs are jobs in firms that export goods or services, or that produce inputs into exported products or services. The latter category is referred to as indirect exports (see, for example, Trade in Value-added: Concepts, Methodologies and Challenges (Joint OECD-WTO Note), https://www.oecd.org/sti/ind/49894138.pdf)
} 
particular. This is especially relevant in high-tariff sectors such as some staple foods and agricultural products in OECD countries.

Women as entrepreneurs: Regardless of the size of the business and the broad sector of activity, womenled businesses trade less than businesses led by men. The report shows that women-led firms are, in general, fewer, smaller, younger and less well financed than those led by men. Barriers that persist to starting and growing their businesses, and to expanding into international markets, include women entrepreneurs' difficulty in accessing credit and finance, the lack of time to devote to their businesses due to their disproportionate amount of unpaid work, shallower professional networks and less experience in entrepreneurship and management. Moreover, women-led firms are more present in services sectors and in particular some sub-sectors that are not traditionally traded which explains in part their absence on international markets. However, a small subset of medium-sized and larger women-led firms trade extensively, even more so that those led by men.

\section{The role of trade policy}

For many of the above issues, addressing the impacts of trade on women, or increasing their participation in trade, lies in the domain of domestic policies - from promoting access to finance, to women's participation in STEM, to greater access to networking opportunities. Although trade policies are not in and of themselves discriminatory, there are some areas where trade policy and trade promotion can play a role in supporting more inclusive outcomes, including as regards women:

- Greater upstream use of gender-differentiated impact analysis to understand the potential impacts of trade policy changes, or new trade agreements on women, including their indirect effects. This can help to inform choices of market opening measures, for example, with a view to promoting greater participation in trade, or greater benefits from trade, or to be ready with appropriate domestic policies should a sector dominated by women face adjustment costs.

- Promotion of trade tools that are advantageous for women exporters, which also include measures that support SMEs' exports, for example:

- Implementing trade-facilitating reforms that reduce fees and charges, and simplify and automate procedures at the border. The automation of the border process can be particularly important for women-led micro- and small and medium-sized enterprises (MSMEs), not only because it reduces the costs of processing documentation, but also because by dematerialising formalities it shelters women entrepreneurs from potential harassment and discrimination. Additionally, reforms that reduce the time required for processes can benefit women who often face additional constraints on their time related to care responsibilities.

- Improve transparency in regulations, including regarding exporting and importing procedures. Greater transparency particularly benefits smaller businesses and those with fewer professional networks, which is the case of many women entrepreneurs.

- Removing barriers to trade, especially trade in services where most women work, has a beneficial effect on the labour participation of women workers and can contribute to a mitigation of existing gender inequalities.

- Regulatory frameworks that support an environment conducive to lowering costs of internet access and liberalisation of logistics services mean lower costs for businesses, in particular for women-owned firms that are smaller and tend to sell to individual consumers.

- Lowering tariffs on essential goods lowers prices and increases purchasing power especially for lower income households where women are disproportionately represented.

- While different countries have different policy approaches to address gender equality issues, some have favoured the inclusion of gender chapters in preferential trade agreements (PTAs) to promote cooperation on trade and gender issues. Although gender-related provisions in PTAs have to date 
been mainly aspirational, countries have used them to create a basis for further dialogue and cooperation amongst the parties on gender issues. A possible approach to further the discussion could be to mainstream gender in other chapters of the PTA.

- For instance, re-asserting legally binding commitments such as ILO Conventions on equal remuneration and non-discrimination in PTAs, and including provisions that call for Parties to sustain and properly implement core labour standards embedded in domestic regulations can promote public awareness of these laws and policies and provide a framework for monitoring previously-undertaken commitments.

- Ensuring the participation of women in consultation and engagement processes for trade policymaking could also promote more diverse perspectives and identify promising paths for addressing gender equality issues.

\section{A proposed Framework for analysing impacts of trade on women}

In order to ensure that the opportunities afforded through trade are shared by both women and men; that trade policies do not hinder efforts to bridge gender gaps; and that coherence with other domestic policies advances goals of inclusiveness, trade policy makers may want to examine in more detail how trade affects women workers, consumers and entrepreneurs. The analytical framework in the final section of this paper could form the basis for country reviews to provide a better understanding at the national level of the current impacts of trade on women and the opportunities for trade and trade policy to be more supportive of women's economic empowerment, including to assist governments in their design of trade provisions and policies and monitor their impacts.

Once women's participation in trade is mapped, policy makers can decide how to ensure that trade is supportive of women's economic empowerment-through greater market access in products and sectors where women work and own businesses; by ensuring women workers and entrepreneurs can engage fully on international markets; through complementary domestic policies to offset negative impacts; or through complementary trade promotion policies that support women so they can fully reap the gains from trade. Such support mechanisms could also target specific demographics, such as indigenous women.

Such a country review would gather and analyse evidence to support gender-responsive policymaking. Data collection efforts can be onerous. Quantitative assessments require statistics for firms, wages and workers to be available by gender - a breakdown rarely available even in more advanced economies. Countries may wish to undertake reviews that include all or parts of the elements of the proposed framework; in this sense it can also function as a menu or checklist where countries may want to focus on specific areas.

The possible areas for inclusion in a gender and trade country review are outlined in the final section of this paper and include the following.

\section{Quantitative analysis of the impacts of trade on women}

\section{Assessing the impacts of trade on women's employment, wages and other job characteristics}

Greater market access in sectors in which women work allows them to engage more in international markets and reap the gains from trade. The design of trade policies and trade promotion initiatives should consider the differential impact on men and women workers and entrepreneurs, so as to better understand whether they promote women's economic empowerment or widen existing gender gaps. Such analysis can also inform the potential to introduce complementary domestic policies in order to narrow gender gaps. The availability of gender-disaggregated data $^{2}$ will be instrumental in undertaking such as assessment. Trade

\footnotetext{
2 While some countries use different terminology to describe "sex or gender disaggregated data/statistics", "gender" is used in this paper to describe the data, in line with terminology used at the WTO.
} 
will not necessarily reduce gender gaps in labour participation but its differential effects on women's and men's employment, wages and other job characteristics, including in sectors that are indirectly engaged in trade, should be identified and measured.

\section{Assessing impacts on women-owned businesses and MSMEs}

Measuring and monitoring barriers to trade in sectors where women-owned businesses tend to be found is crucial to determining their impact. Export promotion agencies can support women entrepreneurs in accessing international markets and increase their capacity to export by facilitating contacts, assisting them in overcoming knowledge gaps and making information about exporting fully transparent and available. It is critical to ensure that these programmes are inclusive of women entrepreneurs.

Moreover, since women-owned firms tend to be smaller, they benefit even more than larger firms from greater transparency in regulation and trade facilitation reforms, in particular the automation of border processes. Trade facilitation indicators and indicators of transparency of regulation should be assessed and can inform trade policy design. Finally market access can also be affected by issues such as lack of access to credit and financing; fewer and shallower business networks; and less time devoted to entrepreneurship due to larger unpaid domestic responsibilities. An analysis of these barriers to entrepreneurship and to trade will inform as to the extent to which women can take advantage of opportunities afforded by trade.

\section{Assessing price effects of trade}

Trade impacts consumers by lowering prices and providing access to a wider variety of goods and services. Lower prices positively impact the purchasing power of consumers, in particular those in lower income quintiles where women are disproportionately represented. Such impacts can be assessed. By allowing goods to be provided on world markets at lower prices than otherwise would be the case, trade can benefit consumers in partner countries as well. Thus market access is a key variable in obtaining these gains.

\section{Broad engagement to support women's economic empowerment}

Trade policies will not bridge gender gaps: many of the barriers that women entrepreneurs face to expanding internationally and establishing and growing their businesses stem from different initial conditions, domestic policies and unconscious bias. A whole of government approach to women's economic empowerment necessitates engagement with legislative bodies and Ministries responsible for domestic policy areas in order to ensure coherence. The main domestic policy areas that influence women's ability to compete internationally include policies that impact work/life balance; access to finance; access to STEM fields; tax systems; unconscious bias; access to professional networks; and ease of starting and closing businesses. A country review could prioritise areas for engagement that are outside the realm of trade policy.

Moreover, stakeholder consultations can be an invaluable tool for incorporating diverse perspectives, identifying promising paths for gender-responsive outcomes and highlighting unintended negative effects. Furthermore, it is necessary to ensure that decision-making processes are inclusive, including with respect to women. This is particularly pertinent since women are generally less engaged in professional networks and may thus not be fully represented in processes that do not aim specifically to include them. A country review could include an assessment of the extent to which existing upstream and downstream consultation processes are inclusive and what more can be done to promote stakeholder engagement by women, who may be less present in consultative processes due to greater demands on their time and fewer professional networks, to better inform gender-sensitive policymaking. 


\section{Introduction}

With the rising mistrust of globalisation, many governments have come to realise the importance of addressing distributional impacts of policies, including trade policies (OECD, 2017a). Although trade has a positive impact through lower prices and higher purchasing power, and creating opportunities for job creation and economic expansion, no longer can aggregate benefits from trade or investment alone be considered sufficient in the context of opening markets. Indeed, policy outcomes must not only deliver improved prospects for economic growth, but they must include or be accompanied by mechanisms to deal with the distribution of those benefits.

Partly in response, some trade policy analysis has increasingly focused on individuals, firms, and subnational entities, aiming to better understand the characteristics of those that gain and lose from greater market openness. OECD and other institutions have done a substantial amount of analysis in order to better understand the trends that are driving globalisation; what types of firms are more likely to take advantage of market openness; the different barriers to trade that small and large firms face; regional impacts of liberalization; differential effects on skilled and unskilled workers; and the impacts of globalization on different groups of individuals. One of those groups that merits further study is women.

Although women now outpace men in education in most OECD countries and have made great strides toward equal rights, gender gaps persist. Women are less engaged in paid work, and when they are, they are paid less. Women advance more slowly in their careers, live on less income, own fewer businesses, are under-represented in public office, are in the minority on boards and in boardrooms and are more likely to work in the precarious informal economy. They are also more vulnerable to external shocks and risk being adversely affected by the confinement measures necessary to tackle COVID-19 (Box 1).

\section{Box 1. Impacts of COVID-19 on women}

The COVID-19 pandemic has had a different effect on women and men due in part to gender differences in income, sectors where they work, and unpaid work.

- Fewer women have died from COVID-19 than men despite that women are overrepresented among the elderly, the most vulnerable group to the virus. Men account for about $70 \%$ of deaths from COVID-19 in Italy, 64\% in China, and 60\% in the United States. This implies that a larger share of the surviving senior population will be women with implications across the policy spectrum including health care and social interaction.

- Although men and women seem to catch the virus at similar rates, women's health seems to be less affected. Suspected reasons include the fact that women have fewer co-morbidities such as heart and lung conditions; men engage in more high-risk behaviour and men are less likely to seek medical attention early.

- Health workers are particularly vulnerable to getting the virus: in the four OECD countries for which comparable data exists, $70-77 \%$ of health workers that caught the virus were women. ${ }^{1}$

- Women are highly represented in the health professions: $70 \%$ of health workers on average are women In the OECD, one-half of doctors and $85 \%$ of nurses are women. Over $90 \%$ of workers in elder care facilities are women. Women health workers suffer from a gender wage gap of $23 \%$ in the health professions (-11\% if accounting for hours worked).

- Women make up a larger share of workers in sectors that have been particularly hard hit by the pandemic such as tourism and business travel services, and are also more likely than men to 
be employed in activities that require face-to-face interactions which prevents them from teleworking (WTO, 2020).

- With the closure of schools and childcare facilities and stay-at-home measures in place, the amount of domestic unpaid work has risen sharply, falling largely to women. Women typically spend $33 \%$ to $66 \%$ more time caring for children than men in the OECD countries with comparable data.

- Single parents - disproportionately women - are a particularly vulnerable group during the pandemic. They are more likely to be at or close to the poverty line, they have fewer childcare options and have no alternative income in case of job loss. Many of the sectors in which women work, namely services, have been hard hit by confinement measures. Many women work either in services that cannot go online - personal services, tourism and hospitality and retail - or in areas that are more at risk due to the lack of possibility to social distance, e.g. child and elder care. In OECD countries with large informal sectors, many informal workers are women. In Mexico, the informal economy accounts for $60 \%$ of Mexican economic activity and women are much more likely to work informally in jobs with no unemployment or health coverage. Social distancing is also more difficult for many professions in the informal economy putting those workers at greater risk.

- Violence against women has risen during confinement. In France, reports of domestic violence against women have risen by $30 \%$ during the lockdown. Many domestic violence shelters and services have closed due to the necessity to maintain social distancing. The economic uncertainty and social isolation that have accompanied the confinement measures seem to have exacerbated existing risk factors.

1. Data refer to Germany, Ireland, Italy and Spain, The Covid-19 Sex-Disaggregated Data Tracker, https://globalhealth5050.org/the-sexgender-and-covid-19-project/the-data-tracker/?explore=variable, accessed 4 December 2020.

Sources: Alon, Titan, M. Doepke, J. Olmstead-Rumsey and M. Tertilt (2020) The Impact of COVID-19 on Gender Equality, NBER Working Paper 26947, April. https://www.nber.org/papers/w26947.pdf; Global Health 5050, Sex, gender and COVID-19, http://globalhealth5050.org/covid19/\#1587664245579-30fa0c77-7d6a; OECD (2020), Women at the core of the fight against COVID-19, https://read.oecd-ilibrary.org/view/?ref=127_127000-awfnqj80me\&title=Women-at-the-core-of-the-fight-against-COVID-19-crisis;

Wenham, Clare, Julia Smith, Rosemary Morgan, COVID-19: the gendered impacts of the outbreak, the Lancet, March 6, 2020, https://www.thelancet.com/action/showPdf?pii=S0140-6736\%2820\%2930526-2; WTO, The Economic Impact of COVID-19 on Women in Vulnerable Sectors and Economies: Information Note, August 3, 2020

https://www.wto.org/english/news_e/news20_e/info_note_covid_05aug20_e.pdf.

Women's economic empowerment makes good economic sense. A study by McKinsey estimated that achieving equality in economic opportunities for women and men could augment world GDP by USD 28 trillion in ten years - about the equivalent of the size of the Chinese and US economies combined (McKinsey, 2015). But at the present rate of change, achieving global economic gender parity will take 257 years (World Economic Forum, 2019). In other words, countries with higher rates of women's employment are utilising their economic potential to a greater extent, which in turn has implications for competitiveness. ILO estimated that reducing the gap in labour participation rates between men and women by $25 \%$ would raise global GDP in 2025 by $3.9 \%$ (ILO, 2017). Apart from the clear economic benefits to be gained by engaging more women in the labour force, there are also other significant positive impacts, such as the improvement in the welfare of women and the opportunity that it affords them to realize their goals (ILO, 2017).

There is a significant role for policy to advance the aim of women's economic empowerment, including through increasing their participation in international trade. Although domestic policy areas are rightly prioritized, trade policy may also have a role to play. The Joint Declaration on Trade and Women's Economic Empowerment (Buenos Aires Declaration) has been endorsed by 127 WTO members and observers who acknowledge that inclusive trade policies can contribute to advancing gender equality and 
women's economic empowerment, which has a positive impact on economic growth. ${ }^{3}$ Further, the Buenos Aires Declaration affirms that improving women's access to opportunities and removing barriers to their participation in trade and investment contribute to sustainable economic development. It upholds the need to develop evidence-based policies that address the range of barriers that limit opportunities for women. Signatories of the Buenos Aires Declaration have agreed to share best practices for conducting gender-based analysis of trade policies and for the monitoring of their effects; and methods and procedures for the collection of gender-disaggregated data, ${ }^{4}$ the use of indicators, monitoring and evaluation methodologies, and the analysis of gender-focused statistics related to trade. ${ }^{5}$ On 23 September 2020, a group of WTO Members established an Informal Working Group on Trade and Gender in order to increase the participation of women in trade, following up on commitments contained in the Buenos Aires Declaration. ${ }^{6}$ Moreover, on 4 August 2020, Ministers responsible for trade from Canada, Chile and New Zealand signed a Global Trade and Gender Arrangement that aims to help "make international trade policies more inclusive and ensure that the benefits of trade and investment are more broadly shared. This commitment is particularly important in the present context, given the common objective to achieve a sustainable and inclusive trade economic recovery from COVID-19."7

Although trade policies are not de jure discriminatory, gender-based analysis of trade policies and the analysis of gender-differentiated, trade-related data can be used to make countries' trade policies and trade promotion efforts more gender responsive by helping to better understand the impact of trade on women and the barriers they face in engaging in international markets. This paper aims to map the possible channels and interactions between trade and gender that policy makers need to take into account when seeking to advance women's economic empowerment. These channels are categorised along three of the economic roles played by women where they are most impacted by trade: as workers, as consumers, and as entrepreneurs and business owners. The interactions between these channels are illustrated in Figure 1.

The paper also considers the role of specific trade policies, and their implementation through trade promotion, and how preferential trade agreements can be supportive of advancing women's economic empowerment. By shedding light on how trade impacts women and men differently, and the barriers women face engaging in international trade and sharing fully in the benefits it can bring, the paper aims to assist governments in their design of trade policies and their implementation, allowing the benefits of trade to be widely shared. While the focus of this paper is on trade policies, given the importance of domestic policies in impacting women's ability to benefit from trade, a number of these are also considered. This paper focuses on the impacts of trade and trade policies on women in OECD countries. ${ }^{8}$

\footnotetext{
${ }^{3}$ https://www.wto.org/english/news e/news17 e/mc11 $12 \mathrm{dec} 17$ e.htm

${ }^{4}$ While some countries use different terminology to describe "sex or gender disaggregated data/statistics", "gender" is used in this paper to describe the data, in line with terminology used at the WTO.

${ }^{5}$ The other areas where countries agreed to collaborate include sharing experiences relating to policies and programs to encourage women's participation in national and international economies and voluntary reporting during the WTO trade policy review process; working in the WTO to remove barriers for women's economic empowerment and increase their participation in trade; and ensuring that Aid for Trade supports tools and know-how for analysing, designing and implementing more gender-responsive trade policies.

${ }^{6}$ https://www.wto.org/english/news e/news20 e/women 23 sep20 e.htm. See WT/L/1095/Rev.1.

7 https://www.international.gc.ca/trade-commerce/inclusive trade-commerce inclusif/itag-gaci/2020-08-04-jointcommunique-commun.aspx?lang=eng

${ }^{8}$ For a comprehensive view of impacts of trade and trade policies on women that focuses more strongly on developing countries see World Bank and WTO (2020).
} 
Figure 1. Trade and gender: An illustrative representation of interactions
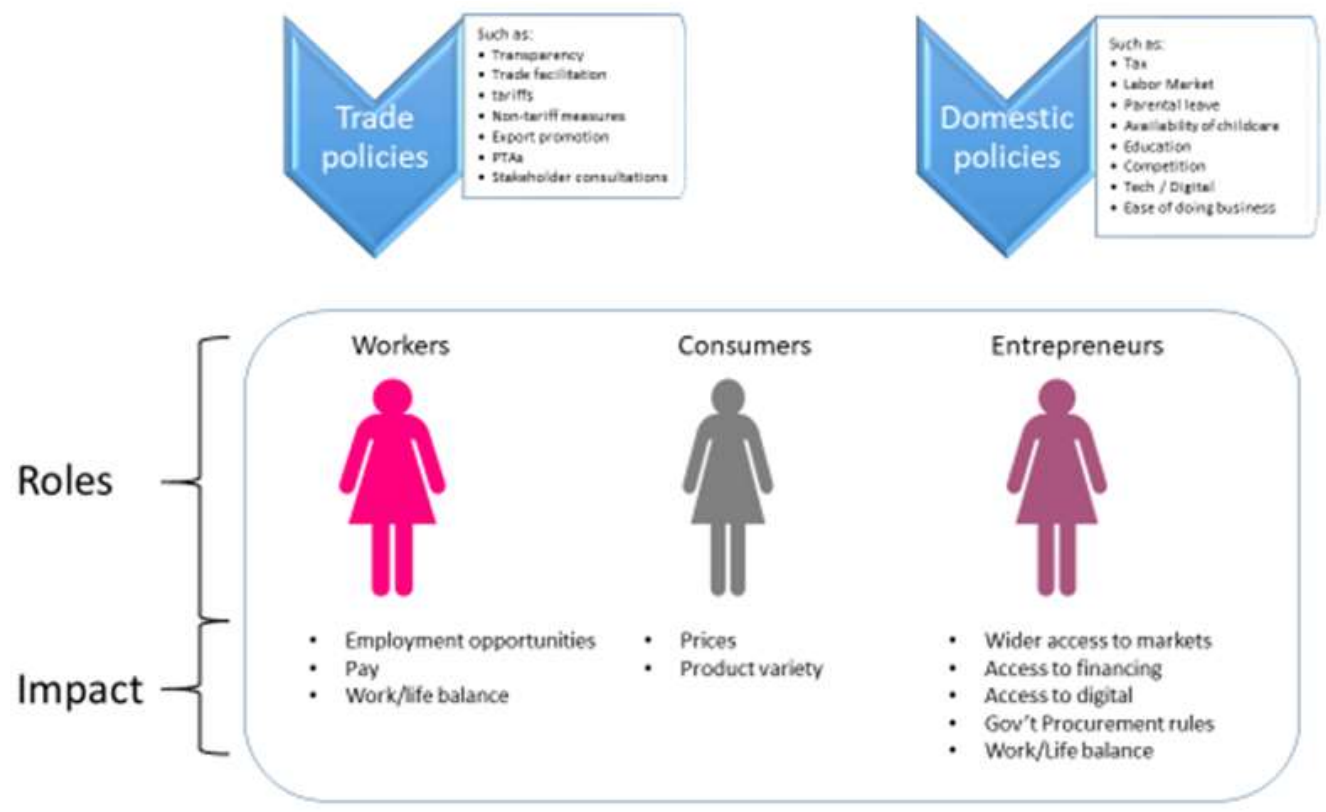

Source: Authors' compilation.

\section{Women workers}

In order to determine to what extent trade policy affects and can affect gender equality in the labour market, this section gives an overview of the current situation in OECD countries as concerns women's participation on the labour market, their sectoral concentration, their share of direct or indirect export-dependent jobs, wage gaps and job quality.

Even though women's labour force participation rates are slowly catching up to men's across OECD countries, women are still lagging behind both in terms of pay and opportunity. Women more often work part-time, are less likely to become managers, and they work in less lucrative fields such as public administration, health and education (OECD, 2017b). It is often around the time of parenthood that more traditional gender norms around work and life materialise more strongly and gender gaps, particularly in terms of earnings, widen (see for instance Angelov et al., 2016).

Available evidence on the link between trade openness and gender equality in the labour market is mixed in OECD countries. First, it depends on the dimension examined - employment, wages, job quality or some other variable. Second, results generally depend on countries' income level, sectoral specialisation, skill distribution, and cultural attitudes towards women. Specific national conditions regarding, e.g. skills of the available labour force and the composition of industry, play a role in determining the effects of increased openness to trade on gender gaps in labour force participation, wages and other job characteristics.

Women's participation in the labour market in OECD countries, and their participation in export-related jobs is examined in this section, including a review of analysis of the impact of trade on women's labour force participation. Until now, few studies measuring the impacts of trade on women's labour force participation have been comparable across countries which limits the extent to which results can be interpreted. A review of the gender wage gap, as well as the gender wage gap in exporting firms, follows, as well as a review of other job characteristics that affect men and women. 


\section{Women's participation in the labour market}

Because of its potential to increase and sustain economic growth and empower women economically, labour force participation is one of the areas that has gained most attention in studies on gender equality. The labour force participation within OECD has increased for women aged $15-64$ from $59.2 \%$ in the year 2000 to $64.6 \%$ in 2018. During the same time, the labour force participation for men in the same age group decreased marginally from $80.8 \%$ to $80.4 \%$ (OECD.Stat).

\section{Trade and women's participation in labour markets in OECD}

\section{Women increasingly work in export-dependent enterprises}

Over the past decade, the number of women working in export-dependent ${ }^{9}$ firms has increased. In 2008 , 31 million women in OECD countries occupied jobs that depended on exports, either directly or indirectly. By 2015 , this number had risen to 39.7 million jobs, an increase of $28 \% .{ }^{10}$ During the same period, women's share in overall employment grew very moderately in OECD from $45.0 \%$ in 2008 to $45.2 \%$ in 2015 (Annex A, Table A.1). In spite of that, the share of women in export supported employment has actually fallen slightly from $39.1 \%$ in 2008 to $38.6 \%$ in 2015 . The reason for this is that even more jobs occupied by men have been created to support exports.

There is some heterogeneity among OECD countries in the share of women's jobs supported by exports. The countries with the highest share of women in export-supported ${ }^{11}$ jobs (as a share of the total number of jobs supported by exports) are Lithuania (45.8\%), Luxembourg (44.2\%) and Latvia (43.8\%); lowest are Turkey (28.8\%) and Chile (31.7\%) (Annex A, Table A.1). The highest increase between 2008 and 2015 in the share of women in export-supported employment was in Iceland (by 3.2 p.p.) followed by Greece (by 3.0 p.p.). The share declined the most in Estonia (down 2.9 p.p.) and strikingly in Latvia (with 2.6 p.p.).

\section{But women still work less in export-dependent jobs than men}

Women are less engaged in export-dependent jobs than men in every OECD country (Figure 2). On average in the OECD, $25.9 \%$ of women and $32.5 \%$ of men are engaged in export-supported jobs. Women's engagement in export-dependent jobs ranges from $57.3 \%$ in Luxembourg to $7.2 \%$ in the United States. The share of workers, both women and men, that are engaged in export-supported employment is largely influenced by the size of the economy - larger countries have larger domestic markets and therefore foreign trade represents a smaller share of GDP and employment in foreign trade is a smaller share of total employment.

\footnotetext{
${ }^{9}$ Export-dependent or export supported jobs are jobs in firms that export goods or services, or that produce inputs into exported products or services. The latter category is referred to as indirect exports (see for example, Trade in Valueadded: Concepts, Methodologies and Challenges (Joint OECD-WTO Note), https://www.oecd.org/sti/ind/49894138.pdf).

10 Estimates of women's domestic employment embodied in exports, both directly (by exporting industries) and indirectly (by upstream domestic suppliers to exporters), are calculated by combining OECD's Inter-Country Input-Output (ICIO) tables (2018 edition) with estimates of employment by industry and by gender, drawing mainly on Labour Force Survey statistics. Currently, the estimates are available for all OECD countries, 36 industrial sectors and for the years 2008 to 2015. They are an extension of the OECD Trade in Employment (TiM) database (see Horvát et al., 2020) and will be updated, using the 2020 edition of ICIO tables, and published online in 2021. The ICIO-based methodology used is similar to that used to generate the indicators in OECD's Trade in Value Added (TiVA) database (see http://oe.cd/tiva). For example, "domestic employment used to meet foreign final demand" complements the TiVA indicator "domestic value added embodied in foreign final demand".
}

11 "Export-supported" and "export-dependent" are used synonymously in this paper. 
Figure 2. Shares of employment depending on foreign final demand by gender

All sectors, percentage, 2015

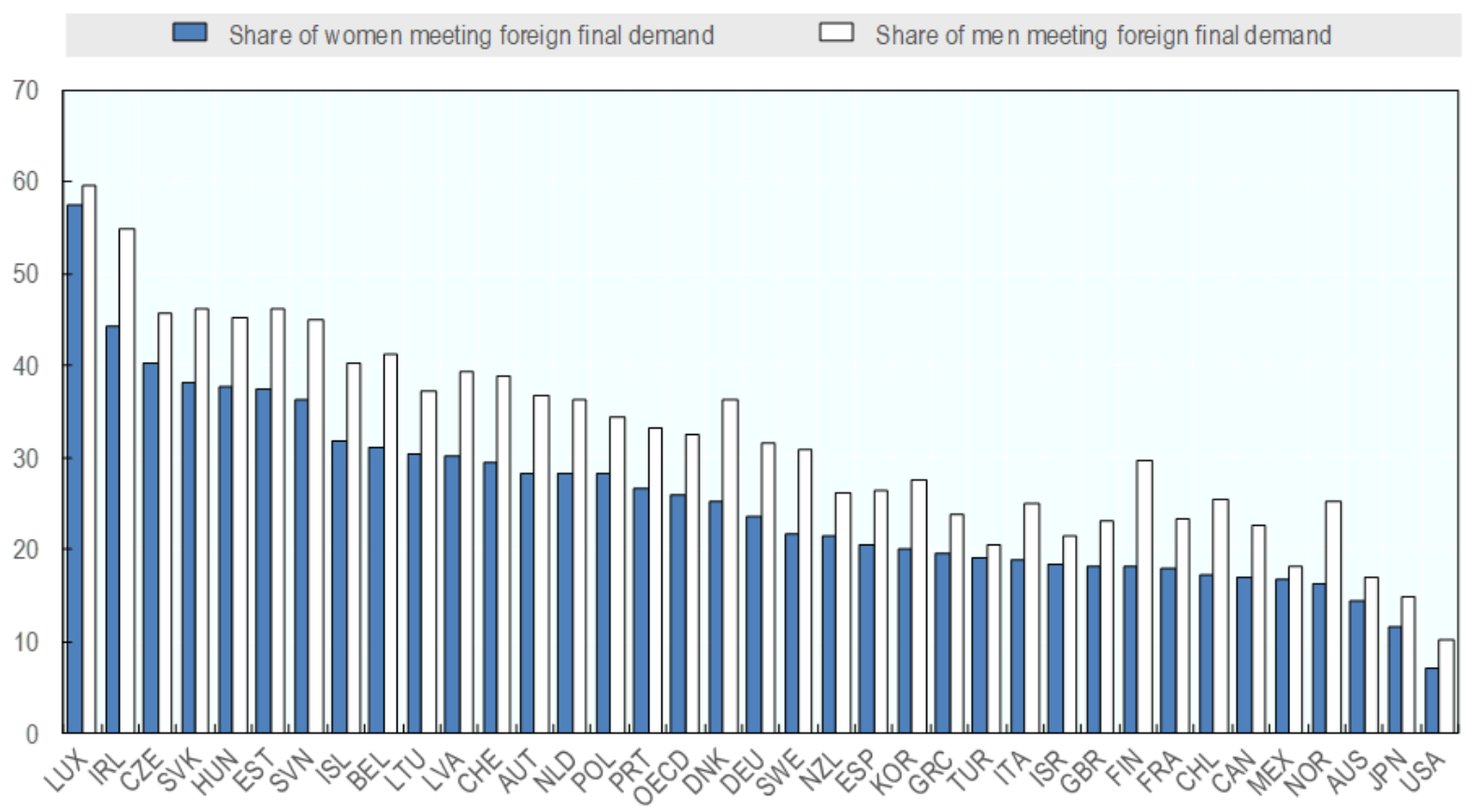

Note: Share of total men's and women's employment respectively. Data ordered by the highest share of women meeting foreign final demand. 2014 data for Mexico.

Source: Secretariat estimates based on OECD's Trade in Employment database, 2019: http://oe.cd/io-emp.

\section{More workers are impacted by trade indirectly}

Many more workers of both genders are employed in indirect exports (upstream suppliers to firms that subsequently export) than in direct exports (the exporting enterprises themselves) (Figure 3). OECD wide, only $7.2 \%$ of working women are engaged in trade directly, but when indirect trade is included, $25.9 \%$ of women engage in trade. Men are more engaged in trade both directly $(8.6 \%)$ and indirectly $(32.4 \%)$. In most OECD countries, the relative dominant share of men working in exports is due to a larger representation in exports indirectly rather than in directly. 
Figure 3. Shares of employment in direct and indirect exports by gender

Percentage, 2015

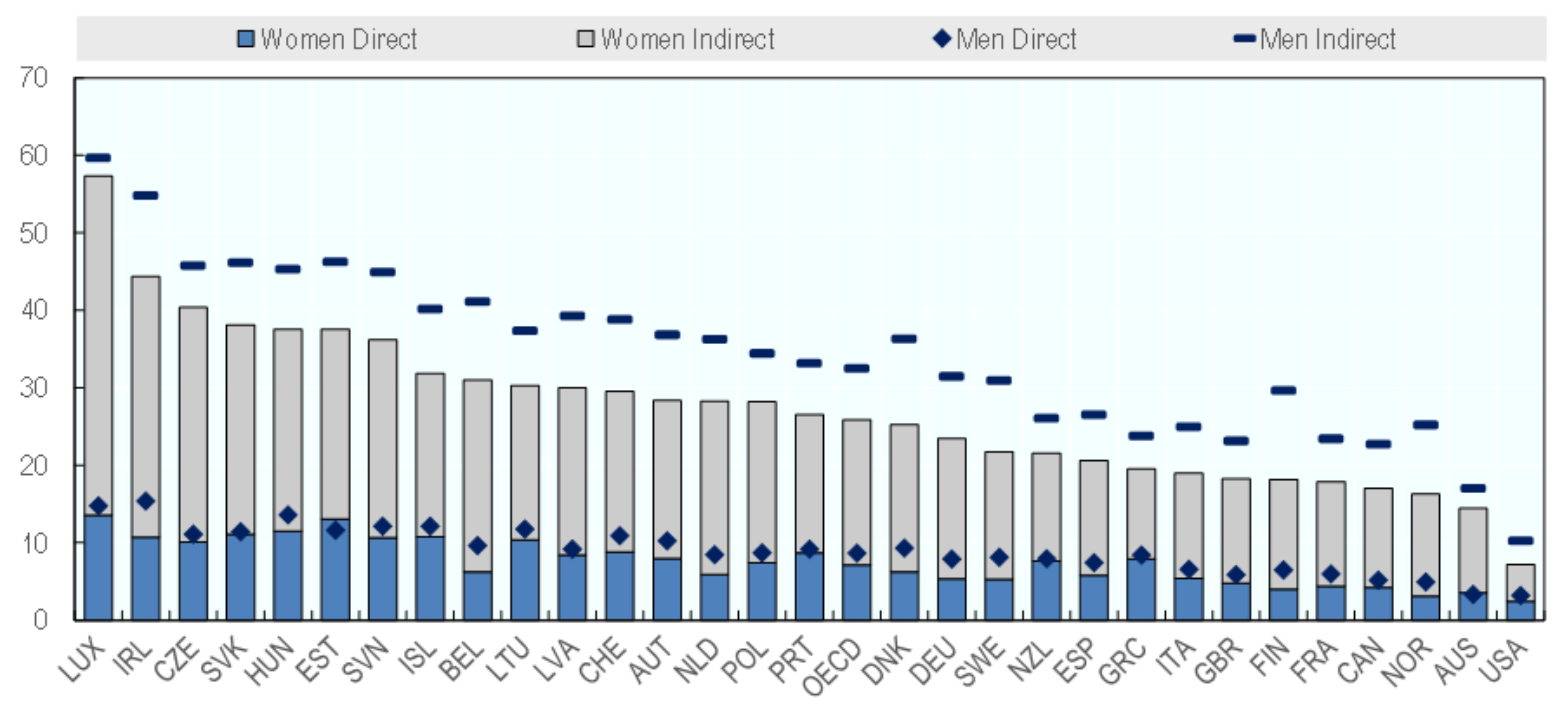

Note: Share of total men's and women's employment respectively. Data ordered by the highest share of women meeting foreign final demand. Source: Secretariat estimates based on OECD's Trade in Employment database, 2019: http://oe.cd/io-emp.

\section{Women work in sectors that are less engaged in trade}

Women's employment is concentrated in sectors less directly connected to trade, notably in public services (Rueda-Cantuche et al., 2019 and 2017; National Board of Trade, Sweden, 2019 and 2020). Within services sectors, business services are more engaged in trade than services such as education, healthcare and administration - and even more so in high-income countries (National Board of Trade, Sweden, 2019 and 2020).

Across all OECD countries, women are much less likely than men to work in manufacturing, a highly traded sector (Figure 4, Panel 1). On average, only $30 \%$ of the manufacturing workforce is made up of women. The share of women workers is higher in business services $-45 \%$ on average (Figure 4, Panel 2) - although they are still less represented in this sector than men in OECD countries. In community, social and personal services, however, women represent a majority (over $67 \%$ on average) of the workforce (Figure 4, Panel 3). These include sectors with very low direct exposure to foreign markets like public administration and defence, education, human health and social work, other services and activities of households as employers. 
Figure 4. Employment by gender meeting domestic and foreign final demand, 2015

Manufacturing

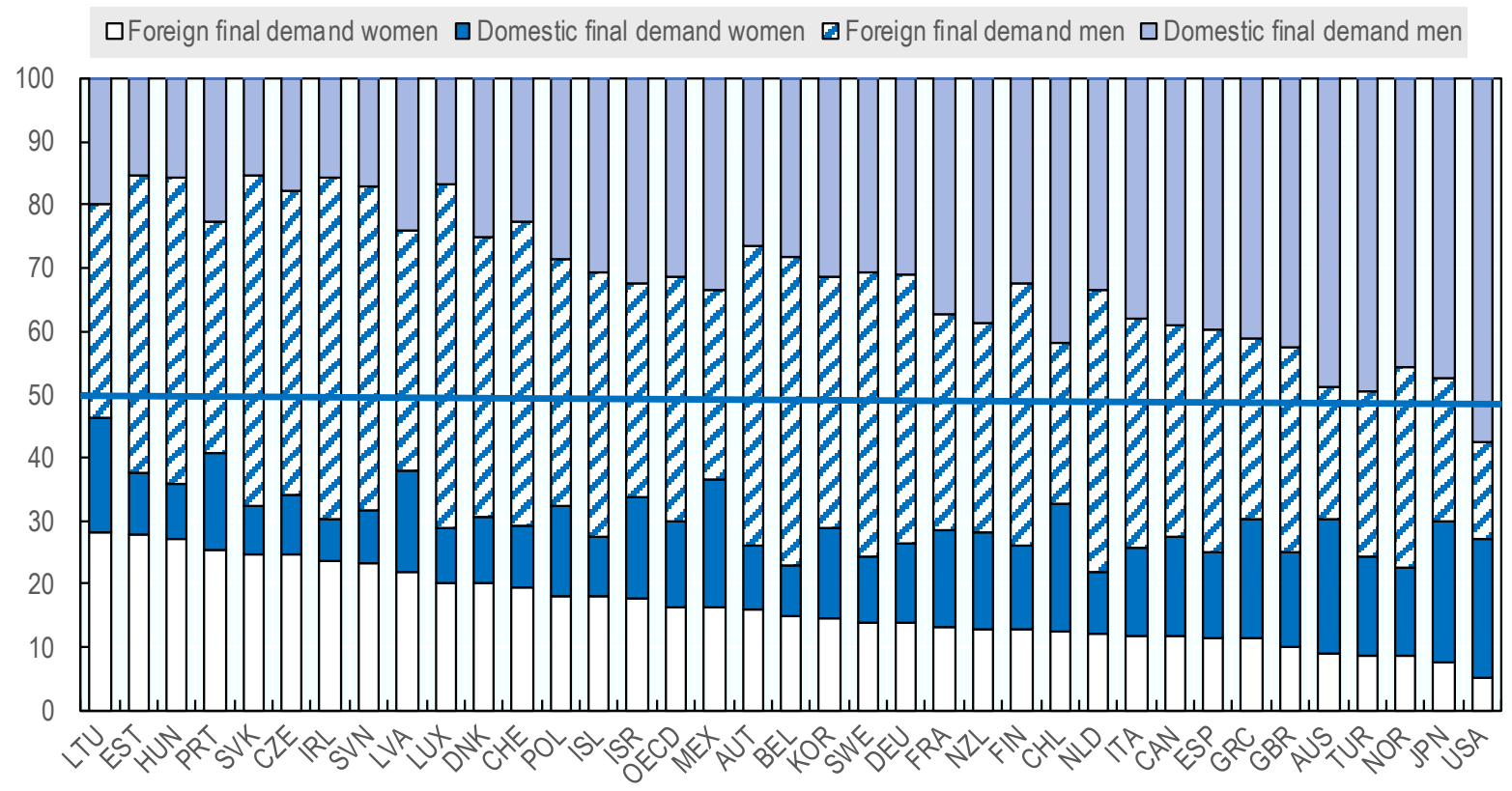

Business services

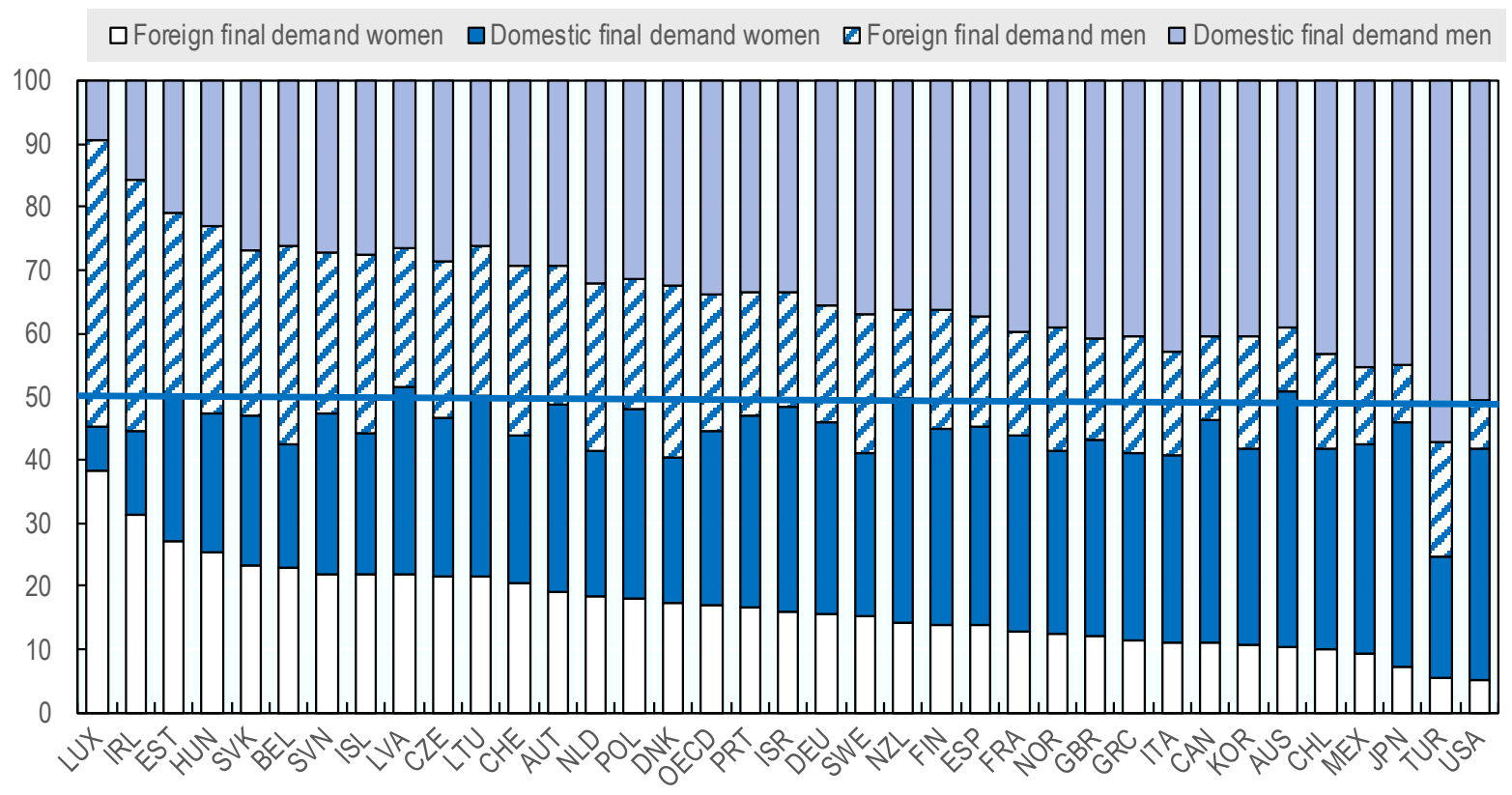


Community, social and personal services

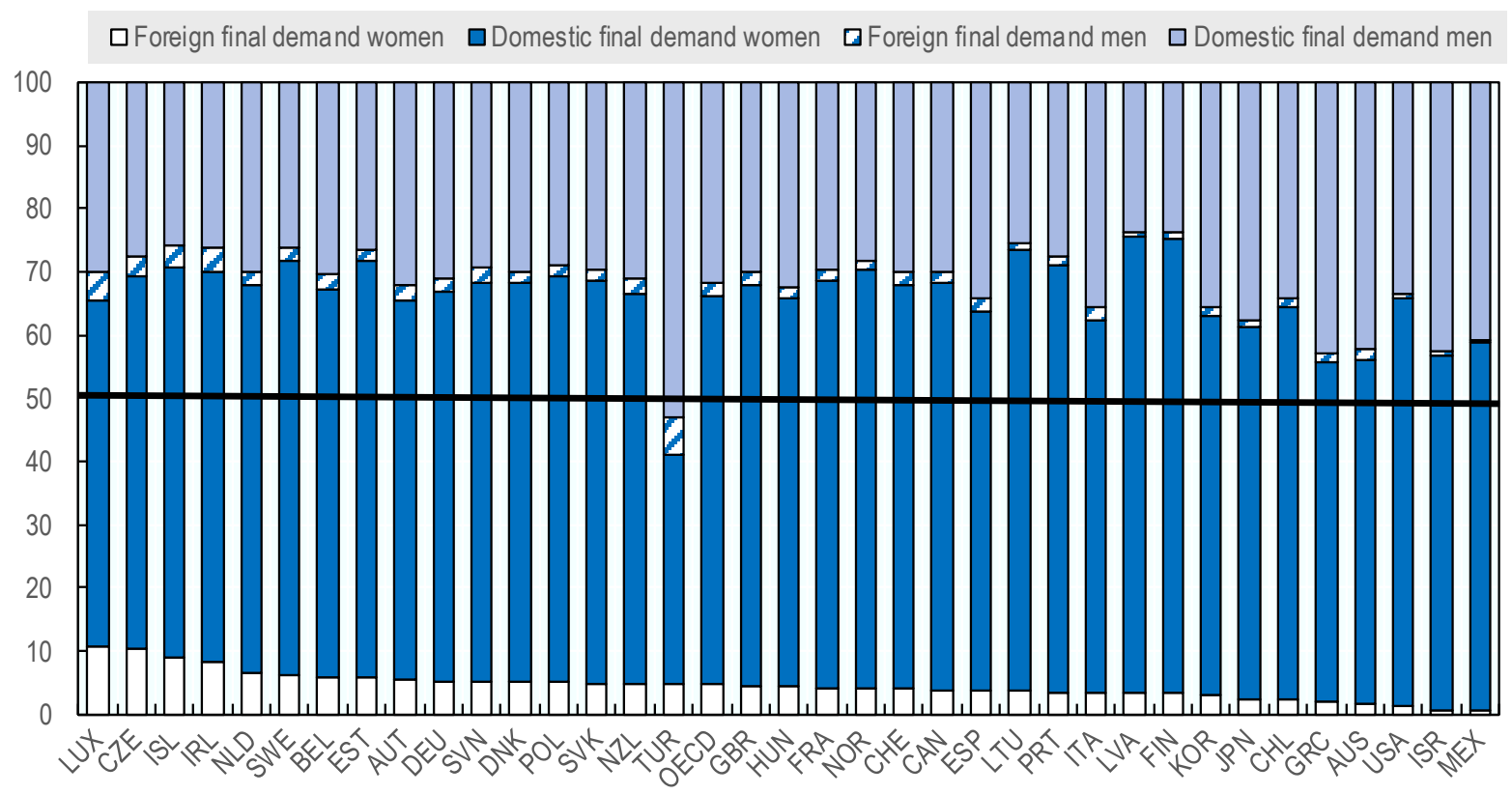

Note: Data ordered by the highest share of women meeting foreign final demand. 2014 data for Mexico.

Source: Secretariat estimates based on OECD's Trade in Employment database, 2019: http://oe.cd/io-emp.

There has not been a substantial change in the share of women in the main sectors of employment, nor a large change in the share of women in export supported employment in these sectors over time (Annex A, Table A.2).

\section{Impacts of trade on women's employment}

Participation in global value chains (GVCs) by importing or exporting directly or indirectly is associated with stronger absolute demand for women in production and non-production jobs (World Bank and World Trade Organization, 2020), as well as, to a lesser extent, stronger relative demand for women production workers $(\text { Shepherd, 2018 })^{12}$. International linkages increase the share of women workers in the formal sector - also in the OECD countries (Shepherd and Stone, 2013), potentially because women may be more flexible in terms of part-time and fixed-term employment and less costly. Worldwide evidence shows that trade can help women move into the formal economy offering better working conditions and access to various benefits. Women workers are less likely to be informal (e.g. working without a contract) if they work in sectors that trade more or are more integrated into GVCs (World Bank and World Trade Organization, 2020).

However, there can be a trade-off between employment and wage levels for women in such cases (Shepherd and Stone, 2017). Equally, lack of international economic ties can retain women in the informal sector and with less formal employment opportunities.

12 The analysis used firm level data from 138 countries (Shepherd 2018). It is important to note that the internationalisation of firms and participation in GVCs is not necessarily always increasing. A study using Swedish data found that the employment share in firms that are directly exposed to international trade was smaller in 2014 than in 1999. The main explanation for this is "a shift in employment towards personal and public services, which is also associated with a high and stable share of women in employment, combined with a growing segmentation of the labour market along the gender dimension" (OECD 2019e). 
Further, trade liberalisation can lead to the introduction of new technologies benefiting women's employment. A study by Juhn et al. (2014) using data from Mexico showed that when companies' export opportunities improved, as in Mexico under the NAFTA agreement, they would adopt new technologies that required less physical strength. This increased demand for women's labour in blue-collar tasks, while leaving it unchanged for white-collar tasks.

Overall, manufacturing employment in developed countries has decreased in past decades, in part due to Chinese import competition, and this effect can be different for men and women workers (CSLS, 2018). In Canada, it was found that during the period in which Chinese import penetration rose significantly (i.e. 2001-2011), the trade-induced job loss was larger for women (CSLS, 2018). This trade-induced job loss was largely driven by low-skilled occupations with high import penetration by Chinese goods. On the other hand, a study from the United States concludes that while Chinese import competition led to a substantial decline in manufacturing employment, losses in men's employment and wages constitute the largest part of this decline (Brussevich, 2018). Women are more likely to be employed in service industries that have been less affected by increased import competition.

Trade has impacted many developed countries' labour markets by increasing job polarisation (WTO, 2017). Trade and technological advances have increased demand for highly skilled workers, and for workers in non-routine low-skilled occupations while "hollowing out" demand for medium-skilled workers. These impacts may affect women and men differently: in the United States, one study found that between 1980 and 2008, women workers experienced job polarisation while men did not (Cerina et al., 2017).

The extent of the impact of import competition on the two genders may depend on the sector of activity and the trading partner. An analysis of women's participation in European countries' services sectors concludes that increased import competition affects working women's and men's employment similarly (Benz and Johannesson, 2019). However, increased import competition negatively affects the hiring potential for women that are outside the workforce (due to unemployment, career interruption, or new entrants into the work force) to a greater extent than men (Benz and Johannesson, 2019). A study on the effects of NAFTA on women's and men's labour force participation found a decrease in women's labour force participation in the United States in industries that were highly exposed to import penetration from Mexico (Sauré and Zoabi, 2014).

The reaction to job loss may also be different between men and women. A study using data from Denmark concludes that rising import competition from China had a significant impact on gender inequality through its effect on the family-work balance. Even though the initial negative impact on earnings from import competition was similar for both men and women, younger women left the labour market in greater numbers to raise a family; correspondingly, the negative earnings impact of import competition on women was higher than for men (Keller, 2019). Indeed, women encountering involuntary exits from the labour market can be more likely than men to drop out of the labour market entirely, to use the opportunity to have children and/or because they are second earners in a household and less mobile in their search of new employment opportunities.

\section{Gender wage gaps}

Around the world, women continue to earn less than men at similar levels of seniority and skills. ${ }^{13}$ Globally, on average women earn $18.8 \%$ less than men (ILO. 2018) while in OECD countries, women earned $13.2 \%$

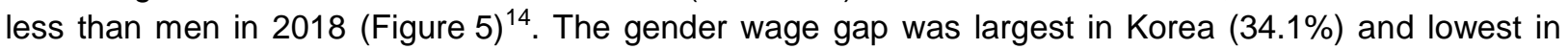

\footnotetext{
${ }^{13}$ See Bøler et al., 2018 for an overview.

14 The gender wage gap is defined as the difference between median earnings of men and women relative to median earnings of men. Data refer to full-time employees on the one hand and to self-employed on the other.
} 
Luxembourg (3.4\%). ${ }^{15}$ Average wages are significantly lower in occupations and sectors dominated by women than in those dominated by men (National Board of Trade, Sweden, 2017). The ILO estimates that if the current trends prevail, it will take more than 70 years to close the gender wage gap (ILO, 2016).

\section{Figure 5. Gender wage gap, employees}

2018 or latest available year, \%

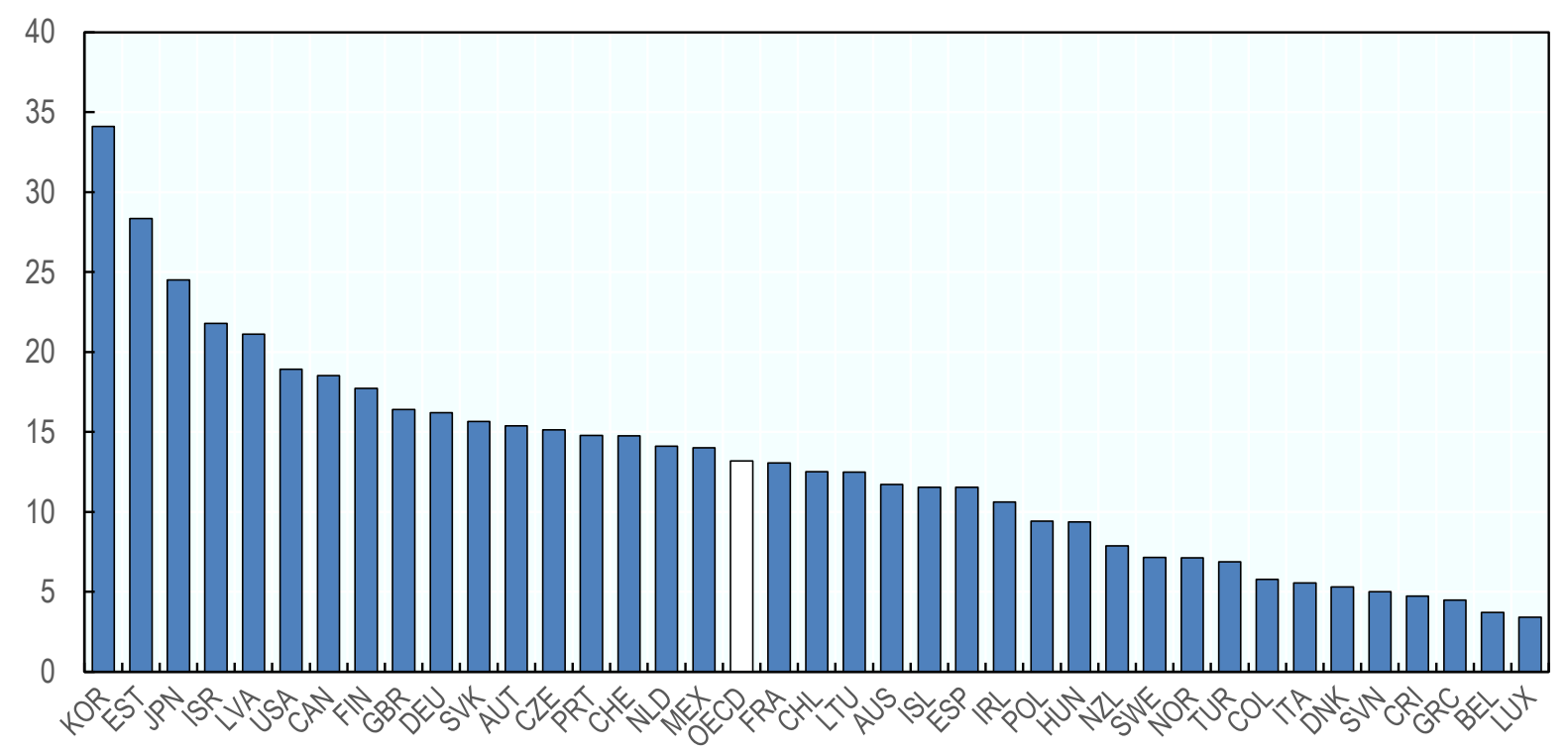

Note: The gender wage gap is defined as the difference between men's and women's median wages divided by men's median wage. Data refer to full-time employees.

Source: OECD (2020), Gender wage gap (indicator).

Women do not attain senior roles, nor are they employed in high-reward segments of the economy, as often as men. Globally, $36 \%$ of senior private sector managers and public sector officials are women. Only $18 \%$ of firms globally are led by a woman, and on average, $22 \%$ of board members in OECD countries are women. This number is even lower outside the OECD area (World Economic Forum 2019). Moreover, gender gaps tend to widen at higher levels of job seniority.

While pay inequality has improved slightly in recent years, and it is worth noting that gaps in participation and pay are narrowest among young men and women. ${ }^{16}$ Gender-related labour market gaps widen when children enter the household, as couples then often take on more "traditional" gender roles (OECD, 2017b).

\section{Impacts of trade on the gender wage gap}

Trade may affect the gender wage gap through a number of different channels. Empirical evidence suggests that increased competitive pressure can force firms to cut costs, especially wage premiums unrelated to productivity, making gender discrimination less affordable. There is much evidence that

\footnotetext{
${ }^{15}$ Mean factor-weighted gender pay gaps worldwide using hourly wages. Income disparities are even larger than wage gaps: women are less likely than men to obtain revenues from non-employment activities such as financial investment (World Economic Forum 2019).

${ }^{16}$ On average across the 29 OECD countries with available data, the gender gap in median hourly earnings for fulltime employed $25-29$ year-olds stands at about $7 \%$, increasing to $13 \%$ for $35-39$ year-olds, $14 \%$ for $45-49$ year-olds, and $15 \%$ for $55-59$ year-olds (OECD, 2017b).
} 
exporting firms tend to be more productive and pay higher wages, but as was seen above, fewer women are employed in export-dependent jobs.

\section{Increased international competition makes discrimination more costly}

The increased competition resulting from trade liberalisation leads to pressure on employers to reduce costs. By eroding the market power of domestic incumbents, trade reduces profits and hence the ability of local employers to incur the additional costs that result from discriminating between men and women (Black \& Brainerd, 2004; National Board of Trade, Sweden, 2019 and 2011). Therefore, more trade is associated with lower levels of gender discrimination.

Conversely, export subsidies, while effective in increasing exports, are found to have the unintended consequence of decreasing employment of unskilled women workers in Chile (López, 2016). Export subsidies are found to allow firms to discriminate against women workers because they provide additional financial resources that firms can use to hire relatively more expensive men. In a more competitive market, employers are less able to fund the cost of discrimination (López, 2016).

\section{Increases in services trade can have a beneficial effect on the wages of women workers}

Trade liberalisation can help reduce wage disparities between men and women, especially if there is a rise in demand in sectors where women work. Measures targeting the removal of obstacles to sourcing foreign services inputs can lead to lower firms' costs and raise the productivity of the employing firm, and could also contribute to narrowing the gender pay gap. Evidence from the UK suggests that higher trade in services tends to diminish the gender wage gap (OECD, 2020b).

\section{Exporting firms pay higher wages}

Many studies find that there exists an exporter wage premium - that exporters pay higher wages than nonexporters (Bøler et al., 2018, Kutlina-Dimitrova et al., 2018; Lindroos et al., 2019; Rueda-Cantuche et al., 2019) and that this wage premium benefits both production and non-production workers. ${ }^{17} \mathrm{~A}$ study using data from European Union finds that on average, exports-supported jobs benefit from a compensation premium of $12 \%$. The highest wage premium (18\%) benefits high-skilled jobs; (Kutlina-Dimitrova et al., 2018). Women workers in export-supported jobs benefit from a wage premium of $13 \%$ over women workers in jobs that do not support exports (Rueda-Cantuche et al., 2019).

\section{The gender wage gap in exporting firms: A positive, but mixed, picture}

However, in some cases the exporter wage premium can be lower for women. A study from Finland finds that trading enterprises are more productive and provide better pay but they have lower participation by women and higher gender wage gaps than non-exporting firms (Lindroos et al., 2019). Gender wage gaps are found to persist in high-tech exporting firms, for example, but have vanished in non-exporting firms. In the Finnish labour market, the gender wage gap tends to be larger in high-paying jobs found in foreign multinationals and in enterprises that trade internationally (Luomaranta et al., 2020).

Similarly, Bøler et al. (2018) using data from Norway conclude that exporters pay substantially higher wages than non-exporters, also for women, but that the gender wage gap is larger in exporting firms than in non-exporters when correcting for differences in worker and firm characteristics. Their results suggest that larger and more complex export operations are associated with a greater gender wage gap. They find that this effect (of around 3 p.p.) is driven by college-educated workers, a result that suggests that women

\footnotetext{
17 However, it is not always the case that a substantial export wage premium exists. In Sweden, for instance, the impact of trade on earnings is, relatively small. This could be explained by the labour market institutions in Sweden with a high unionisation rate and collective bargaining covering essentially all workers and relatively strong job security resulting in a compressed wage structure. In this case, trade has a relatively small impact on wages (OECD 2019e).
} 
are particularly disadvantaged as they compete with men for jobs with higher levels of responsibilities (Bøler et al., 2018).

Within the European Union more generally, for women, export-supported jobs were less grounded in high skilled activities than other jobs in the economy. For highly educated women within the European Union, more employment opportunities could be found in domestic sectors (Rueda-Cantuche et al., 2017).

Moreover, a study from the European Commission concludes that labour compensation for women workers in exports-supported jobs has been declining in comparison to overall compensation since 2008. Although all exports-supported jobs benefit from a wage premium, there is a gender wage premium gap of 4 p.p. in the European Union: Although export-supported jobs are better paid for both genders, on average the export wage premium within the EU is lower for women (13\%) than for men (17\%) (Rueda-Cantuche et al., 2019). There is a substantial difference between countries, however, with $12 \mathrm{EU}$ member countries having a higher export wage premium paid to women compared to men.

In a study on the manufacturing sector in the United States, Gurevich and Riker (2018) conclude that export-intensive industries pay more on average, and that the export earnings premium is larger for women workers than for men. They also find that women workers in the United States have benefitted even more than men from trade agreements enacted with other countries, both in terms of wages and employment (Gurevich et al., 2020).

\section{The gender wage gap in exporting firms can be linked in part to real or perceived flexibility linked to unequal distribution of childcare responsibility}

A number of studies have suggested that the gender wage gap can be explained in part by differences in flexibility regarding working hours between the genders. A study by Goldin (2014) concludes that the gap exists because hours of work in many occupations are worth more at particular moments and when the hours are more continuous. A flexible schedule is worth a high price in certain sectors and occupations, particularly in those that are highly paid.

Exporters doing business with customers located in remote markets and different time zones disproportionately reward flexibility and availability around the clock of their employees (Bøler et al., 2018, using data from Norway). This is found to be true in particular for college-educated workers employed as managers and technicians. If women are less flexible, or are perceived as such, exporting firms will exhibit a higher gender wage gap than non-exporters, particularly among skilled workers (Bøler et al., 2018).

Indeed, women may be less flexible or are perceived as being less flexible. According to some employer surveys, women are perceived as more family oriented than men, less committed to their work, and less reliable than men (Bøler et al., 2018). Further, the magnitude of the gender wage gap in exporting firms is larger for women in their child-bearing years who may be perceived to be less available outside regular business hours. This trend may be exacerbated by the development of communication technology, which brings more flexibility by increasing employee autonomy over time and place of work but may lead to increased expectations with respect to availability via phone and e-mail and a need to adjust working hours to international business partners (Kvande, 2009).

Some evidence suggests that the gender wage gap in exporting companies may diminish in cases where childcare and domestic duties are shared more equally. The gender wage gap in exporting firms has gone down as fathers' share of parental leave has risen in Norway. It is not clear, however, whether the diminished wage difference is driven by differences in constraints, perceptions of these constraints, or perhaps by a general societal change in the perception of work-life balance (Bøler et al., 2018). 


\section{Job characteristics}

Apart from gaps in participation in the labour market and gender wage gaps, a number of additional gender gaps exist in the labour market tied to various job characteristics. The main job characteristics with a gender dimension include skills, job quality, part time vs. full time work, and fixed term vs. unlimited contracts. In countries with high levels of labour market informality, women are frequently overrepresented in informal jobs. These jobs offer little social protection, high job insecurity, and (often) low pay.

\section{Voluntary and involuntary part-time work}

Across OECD countries, women are far more likely than men to work part-time (OECD, 2017b). Women's disproportionate responsibility for unpaid work at home makes it difficult to combine long hours of unpaid work with the long time commitment expected in many full-time jobs (OECD, 2017b). ${ }^{18}$ This is in contrast to men, who are more likely to work longer hours in the labour market, but perform significantly less unpaid work at home, which is the expectation in many countries. Trade can also increase women's participation in the labour market by freeing up time. According to some studies, trade liberalisation measures can reduce the burden of unpaid domestic work if these tasks are transformed into services, including by nonnationals, which are sold in the formal market. This can then liberate time for women to enter into formal employment (National Board of Trade, Sweden, 2017). Another potential time-saving effect from trade would come from lower costs for labour-saving household appliances.

The distributional effects of international trade are not limited to wage effects or net changes in employment numbers. An analysis of women's participation and the quality of jobs in European countries' services sectors finds that increased trade reduces the number of women in involuntary part-time work (Benz and Johannesson, 2019). A 10\% export growth is associated with a reduction in the share of women in involuntary part-time work of almost 1\%: they get full-time contracts instead. By contrast, trade exposure is unrelated to the share of men in part-time work (Benz and Johannesson, 2019).

Job quality

An analysis of women's participation and the quality of jobs in European countries' services sectors concludes that increased trade seems to increase job security for both men and women (Benz and Johannesson, 2019). Export growth is a key factor for workers' job loss risk: an additional $10 \%$ export growth is associated with a reduction of job insecurity of $0.7 \%$ overall, and $1 \%$ when considering only services sectors (Benz and Johannesson, 2019). This effect is similar for men and women.

While export growth is associated with lower job loss risk and better hiring opportunities, it is also linked to a rising share of fixed-term contracts. For men, the growth in fixed-term employment in export sectors is entirely due to rising shares of apprenticeships, indicating that export growth provides opportunities specifically to men who are recent high school graduates. The growth of women's fixed-term employment in export-oriented sectors, however, seems to be mostly due to an increase in the prevalence of involuntary fixed-term contracts (Benz and Johannesson, 2019).

\section{Conclusions}

\section{While trade provides more opportunities for women, gender gaps persist}

Gender gaps in the workplace continue to exist in OECD countries. Although women work more in exportdependent jobs than before, their share in export-supported employment has actually fallen as overall numbers of export-dependent jobs increase. Their participation in trade is considerably higher if women

${ }^{18}$ Greater focus will be placed on unpaid work in the subsequent section on women entrepreneurs. 
working indirectly in trade - upstream suppliers to firms that subsequently export - are also taken into account; however, women are even more underrepresented in jobs that support indirect exports than they are in jobs that support direct exports, compared to men. While trade has increased the opportunities for women, they remain underrepresented due to the segregation of sectors and occupations since women's employment is concentrated in the less export-oriented sectors, notably in services. Even within services sectors, women are employed in the less traded sub-sectors such as education, health, public administration and personal services.

The gender wage gap also persists. While wage discrimination should in principle not endure in an increasingly competitive environment, it has been found to be higher in exporting firms in some countries, even though wages are higher for both men and women in these firms. One factor behind the gender wage gap in exporting firms may be the fact that flexibility offered by employees is worth a high price and women are perceived to have less flexible working hours given the unequal distribution of domestic and childcare responsibilities.

While trade is contributing to new opportunities for women, gender gaps on the labour market exist for a number of reasons. Trade is not the primary cause, and trade policy will not be the primary tool for addressing those gaps - but it can still have an effect on them. In general, internationalisation through openness to trade leads to a stronger demand for women earning relatively good wages in export dependent jobs and can also lead to introduction of new technologies favouring women's employment. Still, a number of additional gender gaps continue to exist in the labour market. External shocks like an economic recession or import competition shocks can affect men and women differently and their reaction may differ with women opting to use forced exits from the labour market as a time to have children (Keller, 2019), or being less mobile in search of new work as they are second earners in households. Women work part time more often than men do and undertake the bulk of unpaid work at home. Trade can have a positive effect on involuntary part-time work and job security, benefitting both men and women.

\section{Women consumers}

There are a number of ways by which trade impacts societies. While the impact of trade on job creation and displacement has been covered by a vast literature, less attention has been given to the impacts of trade through consumption channels. The main reason for this is that it is relatively difficult to pinpoint differences between women's and men's consumption patterns. Most consumer purchasing is recorded at the household level, so distinguishing between goods and services consumed on the basis of gender is a challenging exercise. Moreover, women make the majority of consumer purchases in OECD countries.

One way to differentiate trade's impact on women and men is to look at differences in their purchasing power. Women are more likely to be represented in lower income quintiles. By lowering prices and increasing real incomes, trade impacts consumers in lower income quintiles more strongly, if measured as a share of their income.

This section will start by reviewing how trade impacts consumers, and what we know about its differential impacts by income quintile. It examines women's and men's initial conditions, in particular with respect to income and household composition, which implies dissimilar trade impacts, and then explores results from an OECD study on the distributional impacts of trade policies by income level. The section finishes by examining trade barriers on goods that women and men consume, to the extent that they can be differentiated. 


\section{Trade impacts consumption patterns of women and men differently}

Trade and trade liberalizing reforms impact consumers by lowering prices and providing access to a wider variety of goods and services. Lower import tariffs bring down prices through lower priced imported goods and through greater competition with domestically produced goods (Jaravel and Sager, 2019; Amiti et al., 2019). Greater variety in products also increases households' real income (Broda and Weinstein, 2006). Those that consume more imported goods, or more goods and services with imported intermediates, will be more strongly affected by higher tariffs and non-tariff measures. Consumers in countries with uneven market competition, where some of the rents from lower tariffs can be captured by producers or importers, will not benefit fully from trade liberalization.

\section{Impacts of trade on vulnerable groups: What is known thus far}

Conventional wisdom suggests that trade is generally pro-poor (see, for example, World Bank and WTO, 2015). Trade lowers prices through greater competition and trade liberalization lowers tariffs, which then further lowers prices to consumers. The same import tariff applies to all consumers of a good, regardless of their income. Thus lower income consumers pay more as a share of their income and as such, import tariffs are regressive taxes. Moreover, tariffs are generally higher on food ( $9.9 \%$ on average in OECD) than on manufacturing products (3.3\%), and even higher on staple foods, which are essential to consumers and difficult to substitute. Import tariffs on wheat (12.6\%), rice (24\%), beef, veal and poultry $(13.5 \%)$ and dairy (15\%) increase prices of staple foods to OECD consumers (OECD, 2017a). Tariffs also tend to be higher on cheaper goods: in the United States and the European Union, for example, tariffs on footwear made of plastic face higher tariffs than those made of leather (OECD, 2017a).

Another study finds a "pro-poor bias" of trade in every country in its 40-country sample (Fajgelbaum and Khandelwal, 2016). The authors estimate the loss in real income from closing off trade completely to be $63 \%$ for households in the lowest income decile and $28 \%$ for those in the highest decile. The strong bias in the gains from trade (or losses from the absence of trade) toward poor consumers can be explained by the fact that these consumers spend relatively more on traded goods (Furman et al., 2017; Fajgelbaum and Khandelwal, 2016). Additionally, low-income consumers seem to concentrate spending on products with a lower elasticity of substitution. Larger expenditures in more tradeable sectors and a lower rate of substitution between goods therefore lead to larger gains from trade for poorer households as compared with richer ones.

While other studies find different results concerning the distribution of benefits from trade, generally all income categories are found to benefit from trade through the consumption channel. Using detailed data in the United States, Borusyak and Jaravel (2019) find that distributional effects through the expenditure channel are neutral - poorer and richer households benefit equally from trade - partly because they find similar spending on imports across income groups. He (2017) finds that the expenditure channel benefits the poor more than the rich in every country and even more so in high-income countries. The expenditure channel benefits the poor relatively more in high-income countries because those countries are net importers of goods that are more inelastic to changes in income.

Only one study of those reviewed measures differential impacts of trade on consumers by household composition. It found that in the United States, the highest tariff burden by far is felt by single parent families with children (Furman et al., 2017), most of which are headed by women.

\section{Lower prices on consumer goods will impact women more since they are more likely to be poor}

Lower prices on consumer goods through trade will impact women more strongly than men since they are more likely to be poor. In the United States, women are 35\% more likely to live in poverty than are men. ${ }^{19}$

\footnotetext{
${ }^{19}$ Definitions of poverty and extreme poverty are country specific and have not been harmonised internationally.
} 
In $2015,13.4 \%$ of women and $9.9 \%$ of men lived in poverty in the United States (National Women's Law Center, 2016). Women are also more likely than men to be in extreme poverty: $6.1 \%$ of women and $4.4 \%$ of men lived in extreme poverty in 2015 . Poverty rates are particularly high for women of colour: $23 \%$ of African-American women lived in poverty, $21 \%$ of Native American women and $21 \%$ of Hispanic women (National Women's Law Center, 2016). Women and girls are also more likely to live in poverty in Europe, representing $53 \%$ of people living in poor households (United Nations, 2015).

Single-parent households with children are more likely to be poor and are more likely to be headed by a woman. The proportion of single-parent households has been increasing in the last two decades. Women with children represent three quarters of all single-parent households and in 17 out of 27 developed countries with data, poverty rates in single-parent families headed by a woman are higher than in single-parent families headed by a man, and more than three times higher than in two-parent families (United Nations, 2015). In the United States, more than one-third of single-parent families headed by a woman lived in poverty in 2015 (National Women's Law Center, 2016).

Older women are much more likely to be poor than older men. Among seniors (age 65 and older), women made up two-thirds of those living in poverty in both Europe and the United States (United Nations, 2015 and National Women's Law Center, 2016).

Given that women are disproportionately found in the lower income quintiles, insights can be inferred from the way in which women are impacted by trade through the consumption channel, and the way in which trade impacts lower-income households. A study by the OECD (OECD, 2020c) examines the impact of a number of trade policy scenarios on households at different income levels for two OECD countries, France and Spain. ${ }^{20}$ It is clear from the preliminary results that: (i) trade barriers increase prices and lower purchasing power for consumers, and (ii) lower income households are more strongly negatively impacted by trade barriers as compared with higher income households when undertaking income-based analysis. Given that women are disproportionately represented among lower income households, these results also suggest that trade can have particularly positive effects for women through the consumption channel.

Evidence for France and Spain indicates that the composition of consumption baskets as a share of households' total expenditure does not vary much across income quintiles. In the two countries, rich and poor households spend a similar share of their total expenditure on, e.g., food, housing and utilities. Moreover, a large share of households' expenditure is on non-tradable goods and services, e.g. housing, which represents about a third of expenditure of most households, and up to $40 \%$ of expenditure by households in the lowest income quintile in Spain. ${ }^{21}$

Distributional differences are significant, however, when expenditure is expressed relative to income, due to the increasing propensity to save at higher income levels (OECD, 2020c). In France, households in the bottom quintile spend around $91 \%$ of their income while households in the top quintile spend around $63 \%$ of their income (Figure 6, first panel). A similar spending pattern is also present, although less pronounced, in Spain (Figure 6, second panel).

\footnotetext{
20 Trade policy instruments modelled include import tariffs, non-tariff measures and export taxes. Sectors are modelled at a detailed level and trade impacts expressed by income decile of households. The approach does not allow households to adjust their consumption bundle in response to price and income changes, i.e. consumer preferences are homothetic. The simulations generate changes in final consumer prices of goods and services consumed by households, which then determine the extent to which different income groups are exposed to trade policy driven changes in prices.

21 These findings confirm those for the United States at the detailed expenditure level outlined in Borusyak and Jaravel (2018) who also find consumption patterns similar across income categories.
} 
Figure 6. Expenditure per category as a share of total income in France and Spain

France

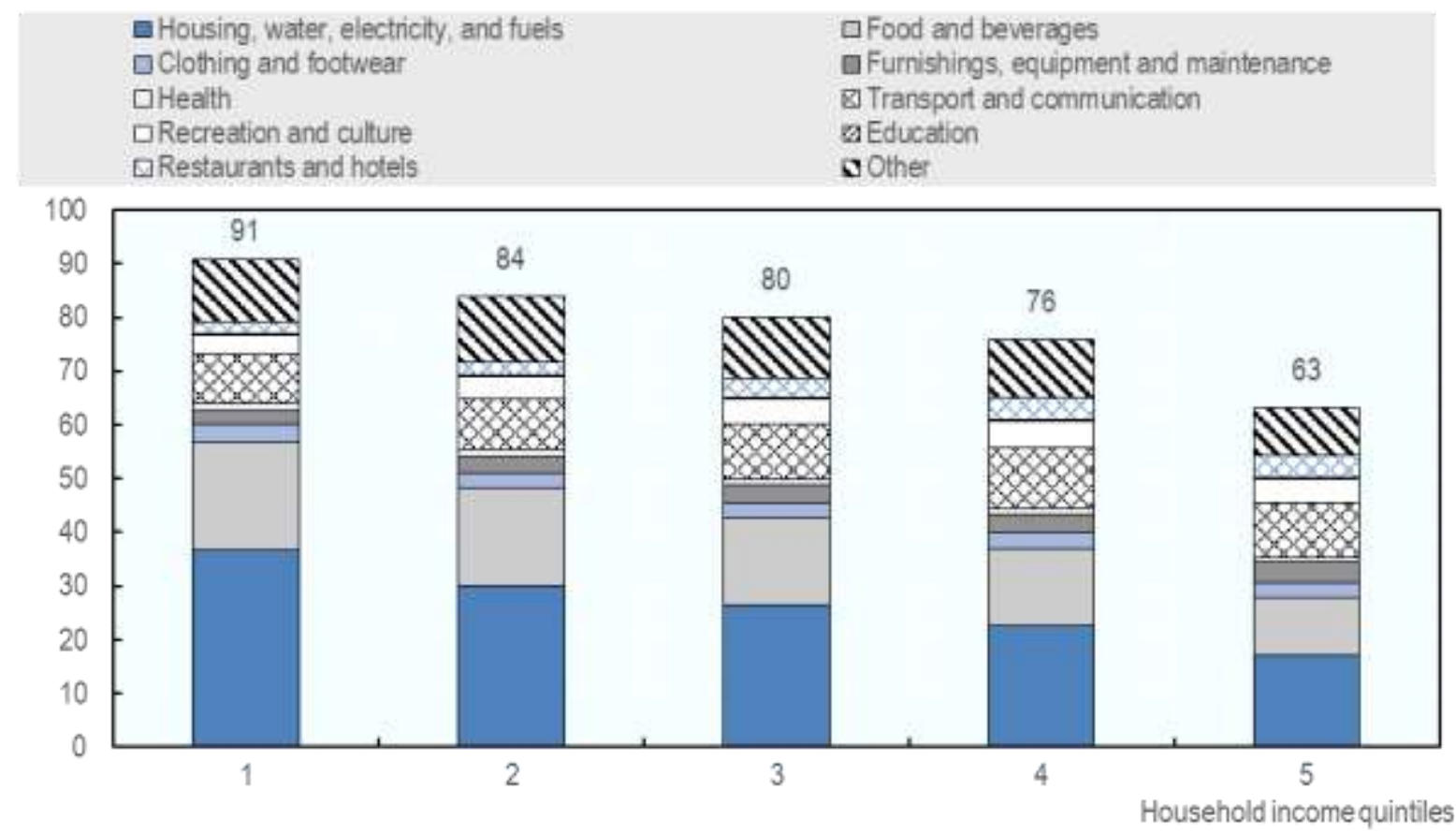

Spain
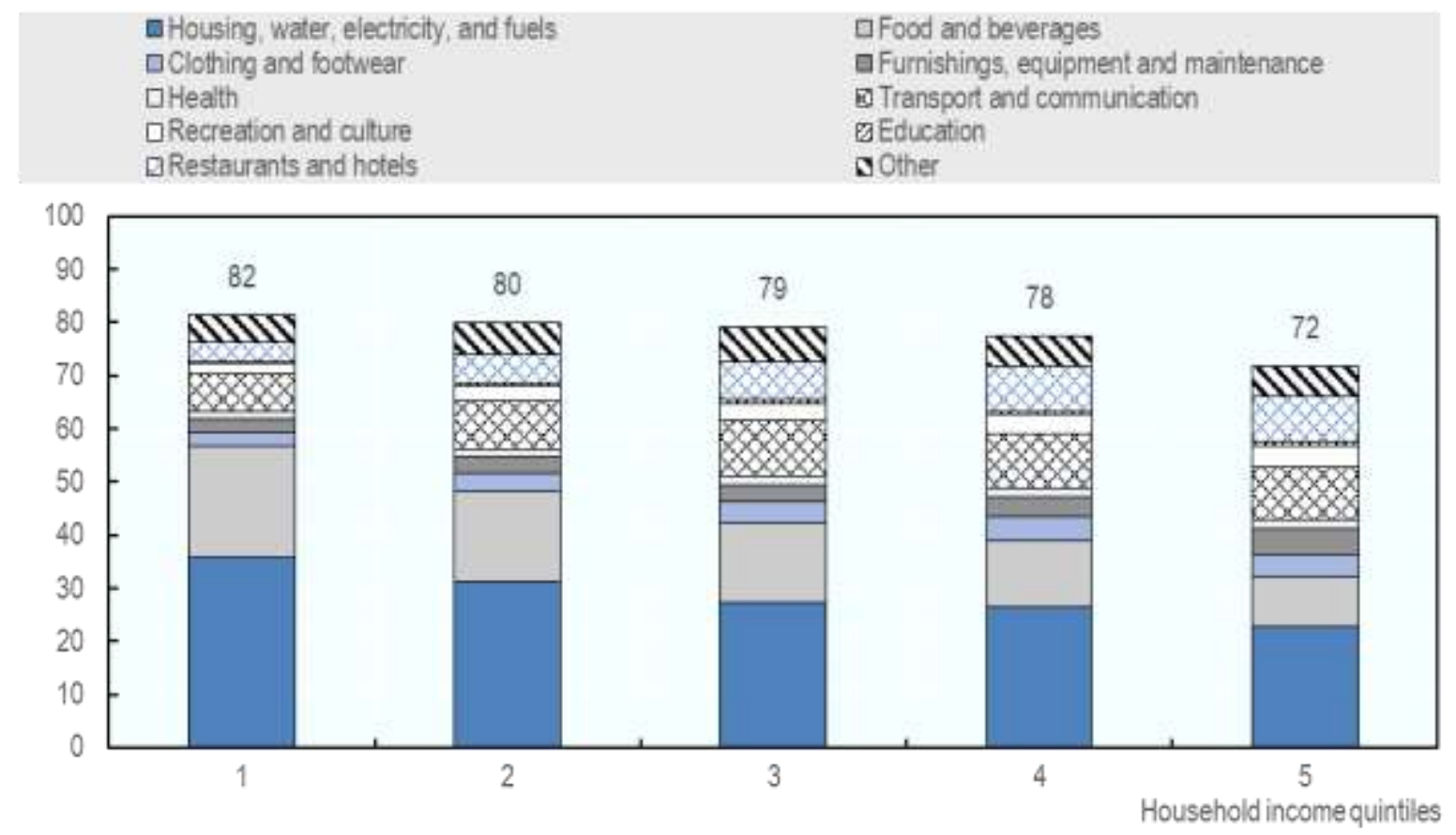

Note: OECD calculations based on 2010 household budget survey (HBS) data for France and Spain.

Source: OECD (2020c).

Results from an illustrative policy simulation show that poorer households, where women are disproportionately found, are more negatively impacted by trade barriers than richer ones because they 
spend a greater share of their income. The policy scenario modelled is a $25 \%$ tariff on all imports except oil and gas from all non-European Union countries; impacts on household purchasing power are computed based both on an expenditure and an income-based approach (OECD, 2019a). On an expenditure basis, rich and poor households are similarly negatively impacted by high tariffs. When taking into account income, however, poorer households are significantly more negatively impacted than richer households (OECD, 2020c).

\section{Gender differences in consumption of a subset of traded goods}

Distinguishing between goods and services consumed on the basis of gender is a difficult exercise: women form a heterogeneous consumer group, and most consumer purchasing is recorded the household level. Moreover, women make or influence about $80 \%$ of households' consumer purchases in OECD countries. ${ }^{22}$

There is some evidence that prices are higher on goods destined for women compared with those destined for men, suggesting that there is a 'pink tax' referring to the colour of the products affected by higher prices. Goods destined for women and girls were found to be $7 \%$ higher in price on average than those destined for men and boys in New York City, even after correcting for potential differences in quality (NYC Dept. of Consumer Affairs, 2015). One potential explanation for these price differences is that women's consumption decisions are seen to be less influenced by price.

Examining tariff schedules for OECD countries provides no evidence of overall gender discrimination in trade policies regarding certain goods differentiated on the basis of gender. ${ }^{23}$ There is little discernible difference in import tariff rates applied by OECD countries on traded goods that can be distinguished as destined for consumption by either women or men, such as apparel items. ${ }^{24}$ This suggests that there is no 'pink tax' in terms of taxes on imported goods in OECD countries (Figure 7). A similar exercise was undertaken for Middle East and North Africa (MENA) countries and for Latin America and no obvious gender discrimination in import tariffs was found there either in recent years.

One product group that applies only to women is feminine hygiene products. ${ }^{25}$ In the Harmonised System (HS) trade classification, tampons and sanitary towels are grouped with diapers in a single 6-digit HS product. In OECD countries, the average import tariff on HS 961900 Sanitary towels (pads) and tampons, napkins and napkin liners for babies and similar articles, of any material was $2.5 \%$ in 2018, down from 4.3\% in 2012 (Figure 8). Highest tariffs on these products were in the United States (6.1\%), Mexico (5.6\%), and New Zealand (4.9\%); in these countries, the tariff rate was substantially higher than overall effectively applied rates (see Annex B Table B.1 for comparisons). Feminine hygiene products entered tariff-free into Iceland, Japan and Norway (Figure 8). Albeit a small share of consumers' consumption baskets, high tariffs increase prices of these first-necessity products, which exclusively impact women, girls and young families.

\footnotetext{
22 Bloomberg "The 10 things everyone should know about women consumers", https://www.bloomberg.com/company/stories/top-10-things-everyone-know-women-consumers/, 11 January 2018.
}

23 This analysis looks at tariff policies, not tariff burdens. Studies examining tariff burdens have found that women account for more tariff revenue on aggregate due to a greater share of their clothing being imported, or spending more on clothing (see, for example, Gailes et al., 2018).

24 It should be noted that these products represent a small share of all traded products. In our dataset, 76 HS 6-digit products are listed as specific to men, and 101 products are listed as specific to women, out of a total of approximately 5300 6-digit products in the entire Harmonised System classification.

25 There have been proposals in some countries to remove domestic (consumption) taxes on tampons and other feminine hygiene products, a debate that has been called the 'tampon tax' (see for example 'Tampon tax abolished from today', https://www.gov.uk/government/news/tampon-tax-abolished-from-today; 'Tax free. Period', https://www.taxfreeperiod.com/; 'Where the "Tampon Tax" is Highest and Lowest in Europe', https://www.statista.com/chart/18192/sales-tax-rates-on-feminine-hygiene-products-in-europe/). 
Figure 7. No gender discrimination found in import tariffs

Average import tariffs on gender-specific apparel, 2018, ad valorem

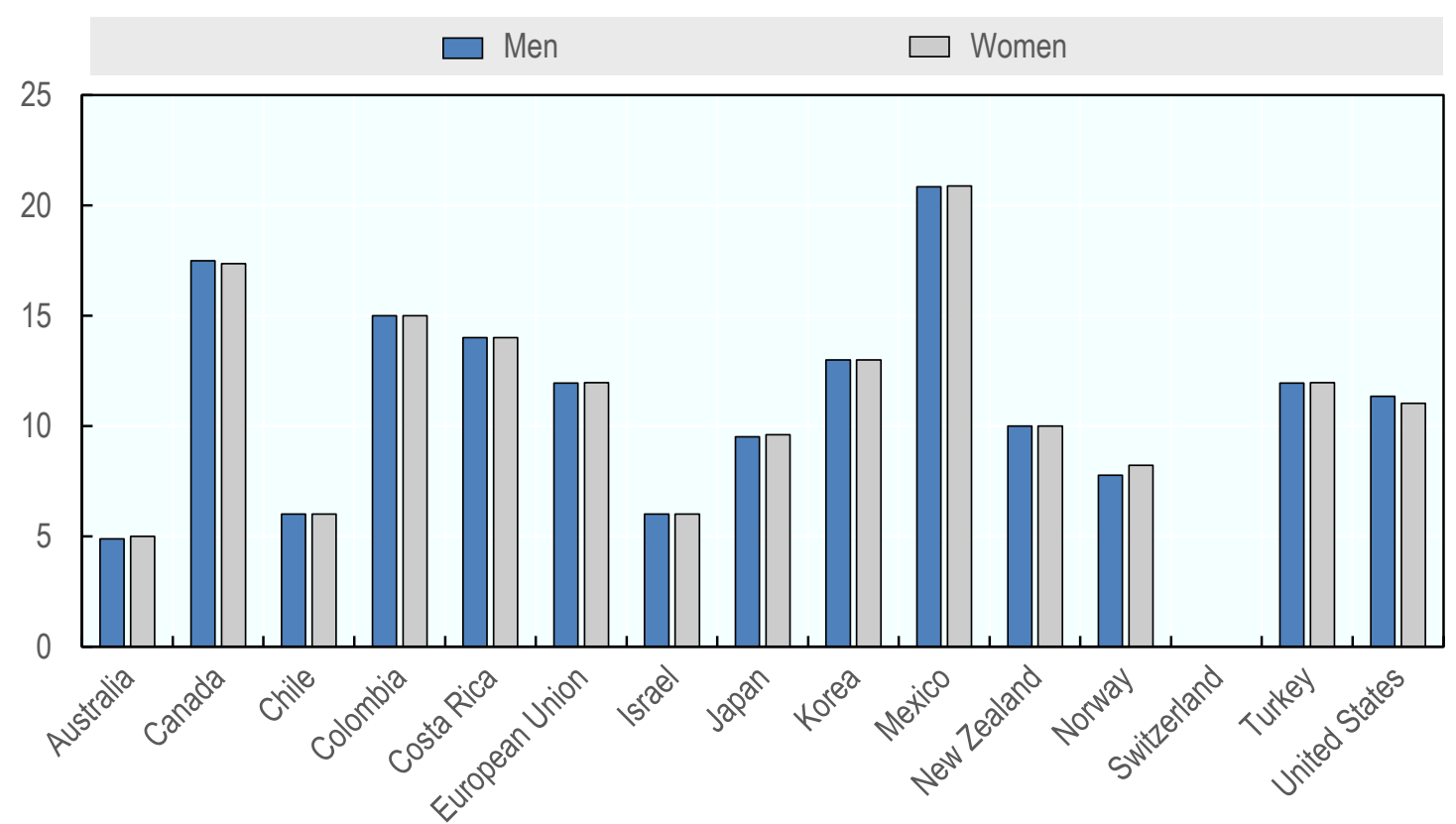

Note: Refers to effectively applied tariffs that are comprised, as applicable, of preferential tariff rates, most favoured nation rates, or bound rates. Tariff rates for individual products are trade-weighted. Using a simple, unweighted average did not significantly impact results. Gender specific products are those at the 6-digit level of the Harmonized System (HS) classification that explicitly contain either the words "men/boys" or "women/girls". All goods belong to Chapters 61 and 62 of the HS classification, and are identified as "Articles of apparel and clothing accessories, knitted or crocheted", or as "Articles of apparel and clothing accessories, not knitted or crocheted". In our dataset, 76 products are listed as specific to men, and 101 products listed as specific to women. Lists of products available on demand. Source: UN Comtrade accessed through the World Integrated Trade Solution (WITS).

Figure 8. Import tariffs on sanitary napkins, tampons and diapers

Ad valorem

2018

$\diamond 2012$

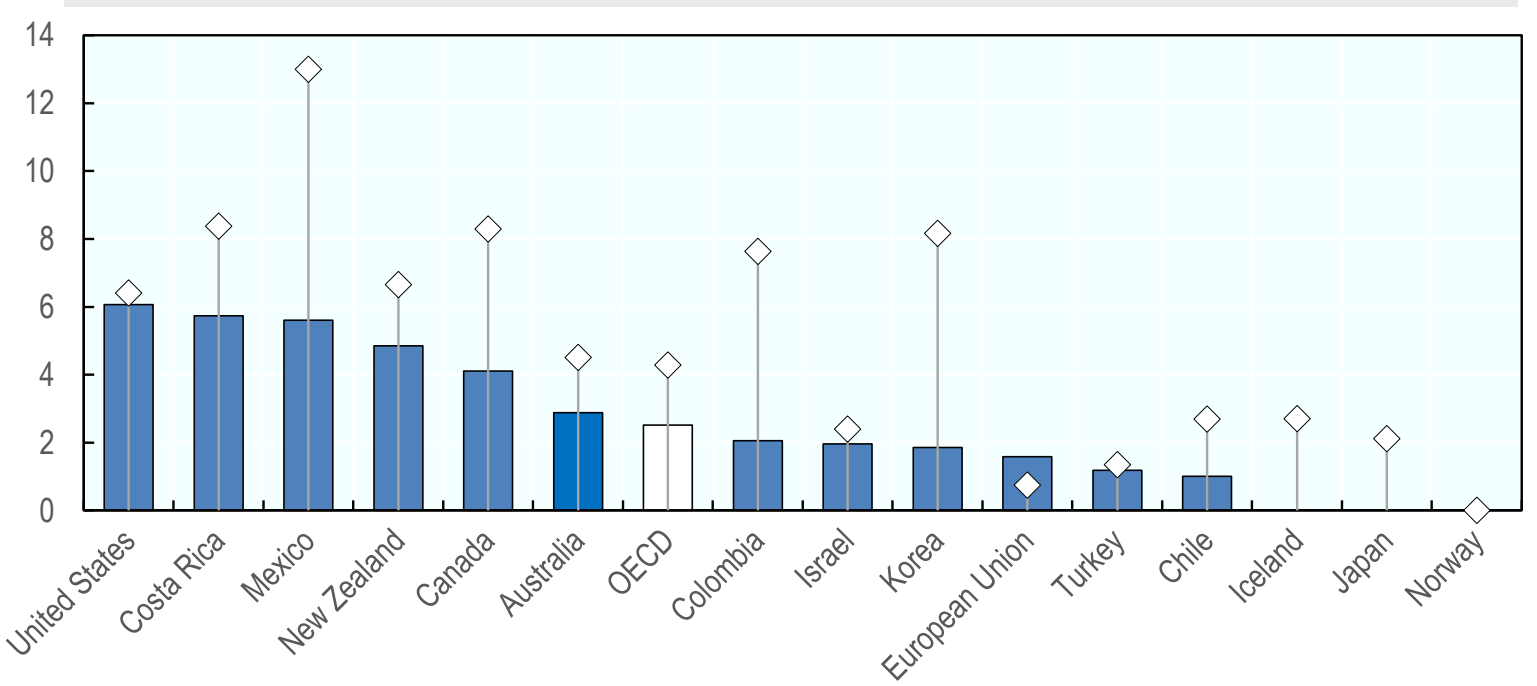

Note: Effectively applied tariff rates on HS 961900. Trade-weighted averages of preferential, MFN or bound rates as applicable. Source: UN Trains. 


\section{Conclusions}

Increases in consumers' purchasing power thanks to the lowering of trade barriers can be substantial. Because they spend a greater share of their disposable income on consumer goods, lower-income households, in which women are disproportionately represented, particularly benefit from lower prices that result from increased trade.

Although there is some evidence that domestic prices are higher on goods destined for women compared with those destined for men, recent evidence for OECD countries indicates that there is no overall gender discrimination in trade policies regarding goods, mainly apparel, which can be differentiated on the basis of gender.

\section{Women entrepreneurs and business owners}

Women owned businesses have different characteristics and face different constraints than those owned by men. This section starts by ascertaining these differences and reviews the barriers that women face in starting and growing their businesses. These aspects impact strongly whether women-owned businesses can expand internationally, and how their business fare if they participate in trade. Many of the barriers that women entrepreneurs face more generally - their relative inexperience, access to finance, access to networks, and less time to devote to their businesses - represent supply constraints that may be magnified when they enter competitive international markets. Moreover, the sectors in which women tend to work and lead businesses - mainly services, which are less traded - mean that they engage less in trade.

The majority of women-owned businesses are micro, small and medium-sized enterprises (MSMEs) and the majority of MSMEs are not engaged in trade. However, OECD analysis suggests that MSMEs benefit even more from policy measures that facilitate trade than larger firms (OECD, 2021). Moreover, womenled businesses may benefit substantially from digital transformations but they also face increased risks compared to men. Women-led businesses generally reap the benefits of international trade less than those owned by men, mostly because they are smaller, less well financed and benefit less from professional business networks; as such, many of the policy responses will need to be in the arena of domestic, rather than trade, policies. This section draws on the Future of Business Survey, a collaboration between Facebook, the OECD and the World Bank to provide data on online firms that have an active Facebook business page. ${ }^{26}$ The Future of Business Survey should not be considered representative of all business owners, but rather micro, small and medium-sized firms with an online presence on Facebook (Goldstein et al, 2019).

\footnotetext{
26 The bi-annual Future of Business survey includes questions about perceptions of current and future economic activity, challenges, strategy, and business characteristics, including the gender of the owner/manager. The survey aims to give a snapshot of small and medium-sized businesses with an online presence. Over 700000 Facebook page owners have taken the survey, out of a population of 90 million businesses that have created a Facebook business page. The survey can be accessed at: https://datacatalog.worldbank.org/dataset/future-business-surveyaggregated-data. The survey was weighted in accordance with the Facebook page administrator population rather than the total business population. Therefore the survey should be regarded as representative of firms with an online Facebook presence rather than the entire business population. Given the global nature of the internet, the size of any truly representative sample is hard to determine.
} 


\section{Characteristics of women-owned and women-led firms ${ }^{27}$}

Women are less likely than men to own and manage a business and their businesses are smaller and younger. Self-employment is widely perceived as a more risky activity than salaried employment, and some studies suggest that women may be less willing to assume high levels of risk. As firm size increases, the presence of women in management and ownership diminishes. Moreover, women-owned businesses generate substantially less revenue. In the United States, women-owned businesses averaged earnings of USD 14900 compared to USD 47900 for all privately held businesses and USD 1.4 million for all firms, including publicly traded companies, in 2019 (American Express, 2019). Women entrepreneurs tend also to have less experience owning and managing a business than men and women entrepreneurs tend to be younger.

Women-owned businesses tend to be concentrated in services sectors. Eighty per cent of women-owned firms are in services compared with $67 \%$ of those owned by men with a Facebook presence (Annex C). In the United States, half of all women-owned businesses are concentrated in three industries: other services, including hair and nail salons and pet care businesses; healthcare and social assistance, including child day care and home healthcare services; and professional, scientific and technical services, including lawyers, bookkeepers, architects, public relations firms, and consultants (American Express, 2019).

The characteristics of women-owned firms - their smaller size, lower turnover, youth as well as the sectors in which they operate - are often associated with lower productivity. Enterprises owned by women are $5 \%$ to $30 \%$ less productive, defined as having a lower value-added per employee, than enterprises owned by men (Piacentini, 2013). The lower capital intensity of women-owned enterprises is the most decisive factor in their lower productivity and explains $38 \%$ of the shortfall (Piacentini, 2013). The industries in which they operate also account for a substantial share of the productivity gap (23\%). A significant fraction of the productivity difference between men and women-owned enterprises, however, is not explained by the observable characteristics of their businesses.

Women start businesses for different reasons than men do. More women than men report that they enter entrepreneurship to "pursue an interest, hobby or passion", "to have a work/life balance satisfying my needs" and "to be more independent" (Facebook-OECD-World Bank Future of Business survey, June 2019, see Annex C Figure C.3). More men lead businesses because they have taken over a family firm or "to make more money" (Facebook-OECD-World Bank Future of Business survey, June 2019, see Annex C Figure C.3). Moreover, women may chose entrepreneurship to a greater extent due to an inability to enter or advance in the workforce, or because they have hit a "glass ceiling" (Annex C, Box C.1). Some women choose entrepreneurship to have more freedom over their working hours given the unequal distribution of domestic and childcare responsibilities.

\section{Barriers to women's entrepreneurship and to growing their businesses ${ }^{28}$}

The smaller size of women-owned and led businesses and their lower productivity can be explained in part by a number of barriers to their entry into entrepreneurship, and their ability to grow their businesses. First and foremost is their lack of access to finance: women entrepreneurs lag behind men entrepreneurs in the amount of credit they request and even more so in the financing that they obtain. Consequently, women entrepreneurs typically start their businesses with less money and are more reliant on self-financing. In seven European Union countries, men are more than 1.5 times as likely as women to report that they could

\footnotetext{
${ }^{27}$ See Annex C for a more detailed description of the characteristics of women-owned and women-led firms in OECD countries.

28 See Annex $C$ for a more detailed description of the barriers to entrepreneurship that women face, and the barriers to growing their businesses.
} 
access the finance needed to start their business (OECD/EU, 2016). The gender gap in venture capital (VC) funding is particularly stark. Only $2 \%$ of VC funding goes to women-only start-ups in France vs. $89 \%$ for start-ups led only by men ( $9 \%$ for mixed teams). Women-only start-ups account for $1 \%$ of total VC funding in Germany and 5\% in the United Kingdom (Boston Consulting Group, 2019). This is significant because venture capital and related risk-finance instruments play a critical role in fostering the scaling-up of the very small proportion of firms that prove to be successful. ${ }^{29}$ Moreover, adequate capitalisation in the start-up phase means a higher chance of achieving greater productivity and of firm survival during the first years.

Women also have fewer and more shallow professional networks. Strong networks can be a crucial conduit for enabling access to capital and are fundamental for smaller businesses to manage common problems, reduce information asymmetry, and build social capital to engage in more distant markets (Ernst and Young, 2013; Bamber and Staritz, 2016). Moreover, even when women join formal networks, they rate the benefits they obtain from them lower than do men. Some women entrepreneurs refer to chambers of commerce and formal business associations as 'old boys' clubs', and report that informal networks are often dominated by men (ITC, 2019).

Women spend less time at work, managing their businesses and engaging their networks in part because they engage in more unpaid work (Annex C). In the United States for example, working women spend half an hour less at work and half an hour more on household chores than their male partners. ${ }^{30}$ Women spend between $40 \%$ and $350 \%$ more time than men on household chores and caring for children and elders in OECD countries that have available data. This situation has been exacerbated by the substantial increase in at-home, unpaid work during the COVID-19 pandemic (Box 1).

Moreover, women often report that they do not have the skills required to pursue entrepreneurship, such as business and financial planning, to a greater extent than men, although they are generally better educated. Women tend to have less experience in self-employment and continue to have fewer opportunities than men in management positions, which acts as a barrier to gaining management experience and skills that are useful for entrepreneurship (OECD, 2019c).

\section{Women-owned businesses and trade ${ }^{31}$}

Exporting enterprises have been found to be more productive and more productive firms tend to export (Baldwin \& Yan, 2015). High growth firms in Canada have higher export intensities (approaching 10\%) compared to firms with no growth (3\%) (Bélanger Baur, 2019). Given that women-owned firms tend to be smaller, less well financed and therefore less productive, it would be expected that women-owned firms export less. Moreover, women-owned firms are highly represented in services sectors, which are generally

\footnotetext{
${ }^{29}$ While VC funds are invested in only $0.2 \%$ of new businesses in the United States, $43 \%$ of US public companies founded between 1979 and 2013 were VC-backed, and they accounted for $82 \%$ of the total research and development expenditure of public companies (Breschi et al., 2018). However, there are substantial differences across OECD countries in the relative size of the venture capital market, with economies like Israel and the United States having a VC-to-GDP ratio ten times as large as the average European country (OECD, 2015).

30 The American Time Use Survey 2019 results, US Labor Department, https://www.bls.gov/news.release/pdf/atus.pdf; Wall Street Journal, "Women Working Longer Hours, Sleeping Less, as they Juggle Commitments", 19 June 2019.

31 Much of the information in this section relies on the bi-annual Future of Business survey of businesses with a professional Facebook page. It is a collaboration between Facebook, OECD and the World Bank. The survey includes questions about perceptions of current and future economic activity, challenges, strategy, and business characteristics, including the gender of the owner/manager. The survey aims to give a snapshot of small and medium-sized businesses with an online presence. Over 700000 Facebook page owners have taken the survey, out of a population of 90 million businesses that have created a Facebook business page. The survey can be accessed at: https://datacatalog.worldbank.org/dataset/future-business-survey-aggregated-data. It was weighted in accordance with the Facebook page administrator population rather than the total business population. Therefore the survey should be regarded as representative of firms with an online Facebook presence rather than the entire business population.
} 
less involved in direct trade than manufacturing. This is borne out by the information on firms with a Facebook presence. Women-led firms are less present both as exporters and as importers (Figure 9).

\section{Figure 9. Share of firms with a Facebook presence that trade by gender}

Entrepreneurs' answers to the question "Does your firm engage in international trade?", \%

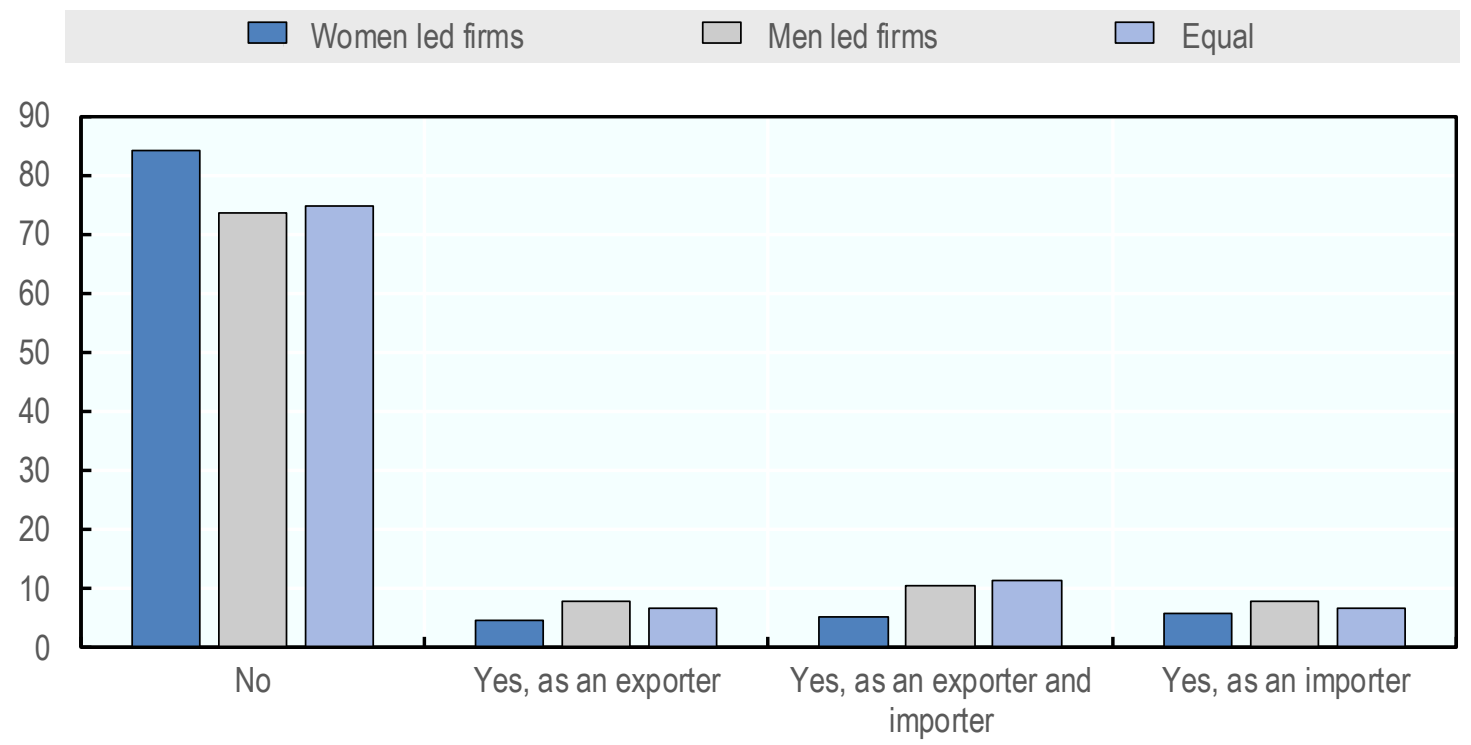

Note: Firms with a Facebook business page.

Source: Facebook-OECD-World Bank Future of Business survey, June 2019.

Since women-owned firms export less, they do not take full advantage of increased opportunities for expansion and economies of scale offered by direct engagement in international markets. That said, they may engage in trade indirectly by selling to domestic firms or affiliates of foreign multi-national enterprises (MNEs). Over half of the intermediate consumption by foreign affiliates is supplied by domestic SMEs (OECD, 2019a). Women-owned firms also import less and thus may not be accessing potentially lower-priced or more competitive inputs into their production processes. But the lower levels of trade cannot be explained by the relatively smaller size of women-led firms: women-led firms of all sizes trade less than men-led firms of similar size with a Facebook presence in OECD countries (Figure 10). The size category where women-led firms are closest to trading as much as men-led firms is medium sized firms, where women-led firms may even import slightly more than men-led firms.

Firms in services sectors are generally less directly involved in trade compared to manufacturing firms although the lower levels of trade by women-led firms cannot be explained either by their prevalence in services. Data on firms with a Facebook presence shows that women-led firms in services sectors, as well as in manufacturing, trade less than those led by men. ${ }^{32}$ The only sector in which women-led firms trade more is construction, a sector where women entrepreneurs are very rarely present which may call into question the representativeness of the data. Women-led firms export and import much less than those led by men in the manufacturing sector, which is generally a highly tradeable sector (Figure 10).

\footnotetext{
${ }^{32}$ A more granular sectoral analysis by type of services and manufacturing sub-sector would be desirable in order to better understand if women-led businesses are particularly prevalent in certain sub-sectors that are less tradeable but this is not yet possible using the Future of Business survey.
} 
Smaller firms may be particularly challenged to compete in international markets in services. Almost $60 \%$ of services trade in 2017 was delivered through mode 3 - provision through a foreign affiliate - which lowers trade costs compared to other modes of services delivery (WTO, 2019). However, it is costly to set up a foreign affiliate and requires access to finance. Since women-owned firms are generally smaller and have less access to finance, they may be less able to engage in mode 3 and thereby take advantage of lower trade costs provided by a commercial presence abroad.

Figure 10. Share of firms that trade by size and sector

Answer to the question "Does your firm engage in international trade?", \%
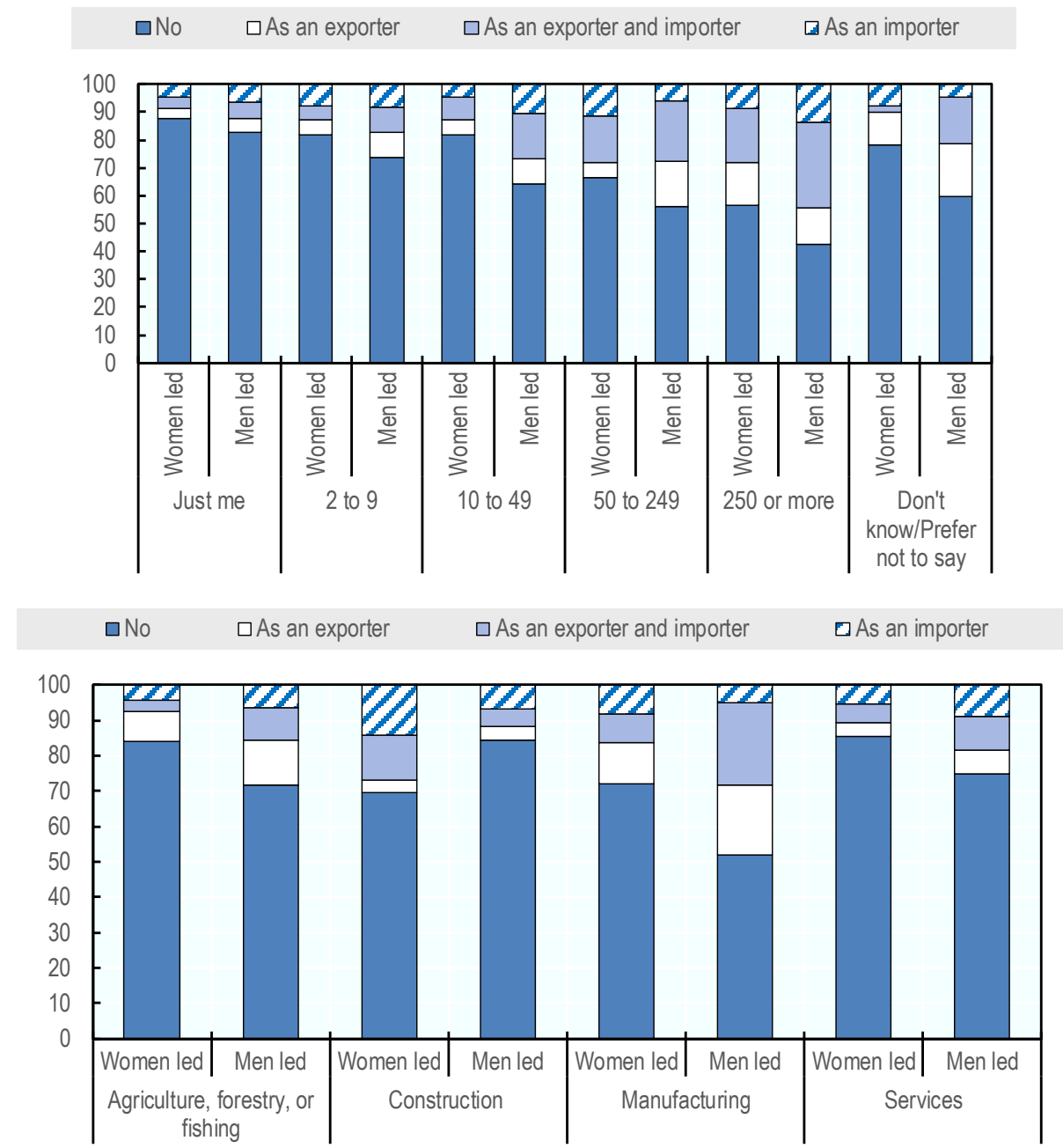

Note: Firms with a Facebook business page.

Source: Facebook-OECD-World Bank Future of Business survey, June 2019.

Of the firms that trade, however, certain women-owned firms trade extensively, outpacing men-led firms. Women-led small firms (10-49 employees) that trade are more likely to export to six or more countries than their men-led counterparts (Figure 11). And women-led larger firms (more than 250 employees) that trade are far more likely to export very widely (to 11 or more countries) than their men-led counterparts. This points to a small number of women entrepreneurs that are highly focused on growing their businesses internationally. 
Some women-led firms export to a large number of smaller clients compared to exporting firms led by men. Women-led firms with a Facebook presence are over twice as likely as men-led firms to export only to individual consumers whereas men-led firms are more than twice as likely to export only to businesses (Facebook-OECD-World Bank Future of Business survey, June 2019). This suggests that even womenled firms that export considerably may need to increase their extensive margin (i.e. the number of foreign clients) substantially in order to increase their intensive margin (i.e. the revenue they obtain from their exporting activity). This finding holds even when correcting for the size of firms - women-led businesses sell more to individuals and less to businesses compared with men-led firms regardless of their size.

Figure 11. Number of destination countries by size of exporting firm

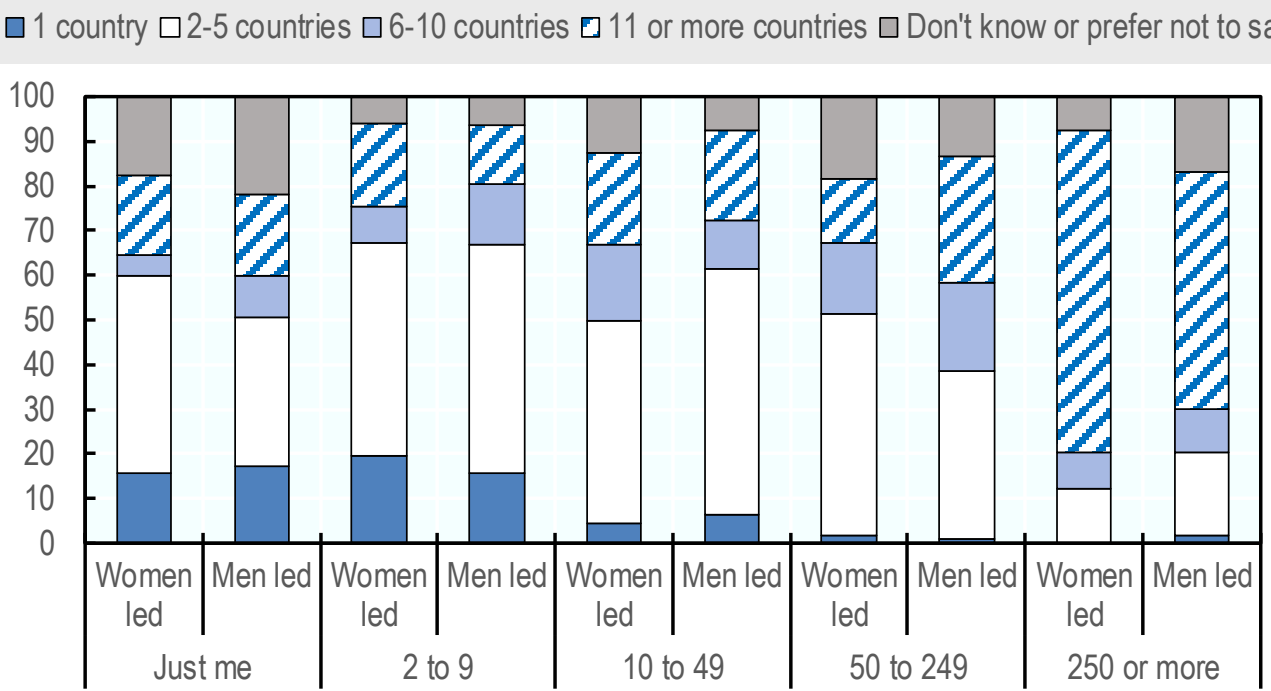

Note: Firms with a Facebook business page.

Source: Facebook-OECD-World Bank Future of Business survey, June 2019.

When asked what barriers they face to trade, women entrepreneurs report similar challenges as those that impede them from growing their businesses more generally, which suggests that policy responses may largely need to be domestic rather than trade-related. The main areas where women entrepreneurs say they face higher barriers to trade than men are: large geographical distance from home country; securing export financing; and different regulations in other countries (Figure 12). Large geographical distances will pose more of a problem to women if they assume most of the responsibility for childcare and housework which gives them less flexibility to travel or even engage remotely with clients or suppliers in different time zones. Lack of export financing is a barrier specific to exporters but also recalls the wider systemic barrier to women-led firms in accessing finance more generally, as described previously and in Annex $\mathrm{C}$. The fact that women-led firms find different regulations in other countries a substantial barrier to trade, and more of a barrier than their men-led counterparts, suggests the need for a targeted policy response, particularly as regards export assistance for women-led MSMEs. Women may find different regulations a greater barrier to export because their more shallow networks may not inform them about export challenges and strategies to the same extent as men's networks.

A survey of women exporters in Canada suggests that they are more affected by logistics, border procedures and administrative barriers to exporting as compared with men-led firms (Sekkel, 2020). This suggests that trade facilitating policies at and behind the border would be particularly impactful for women entrepreneurs. Moreover, although women entrepreneurs are often in less-traded services sectors, the 
study suggests that the largest sector where Canadian women exporters work is in retail trade where getting goods across borders is of high importance (Sekkel, 2020). The World Bank and WTO find that women-led businesses are subject to trade costs that are 13\% higher than those led by men (World Bank and WTO, 2020; 27 of the 33 countries in the sample are OECD countries). Product standards and certification procedures, burdensome customs and administrative procedures, and obtaining import licenses are examples of non-tariff measures that make it costly for firms to export and import, and are exacerbated in the context of global value chains (World Bank and WTO, 2020).

The smaller size of women-owned and women-led businesses as well as women entrepreneurs' smaller professional networks suggests that trade policies and trade promotion initiatives that address the challenges of small businesses and lower information barriers will benefit women exporters. Making information regarding exporting opportunities and export procedures more accessible will particularly benefit women entrepreneurs. In some countries, programs aimed at women exporters support them in taking advantage of the opportunities offered by trade and trade agreements by activities such as information sessions on export procedures or access under a given trade agreement. Some export promotion agencies organize missions to international trade shows, or to specific countries in the context of a trade agreement, and ensure a gender balance in participants. Services such as those provided by Trade Commissioners are particularly useful for women entrepreneurs since they help lower information barriers. The Organization of Women in Trade (OWIT) network exists in over 20 countries and some of the chapters in the United States have organized trade missions for women entrepreneurs in conjunction with the US Trade Commission and consulates.

\section{Figure 12. Main challenges faced by businesses that export}

Percentage responding affirmatively

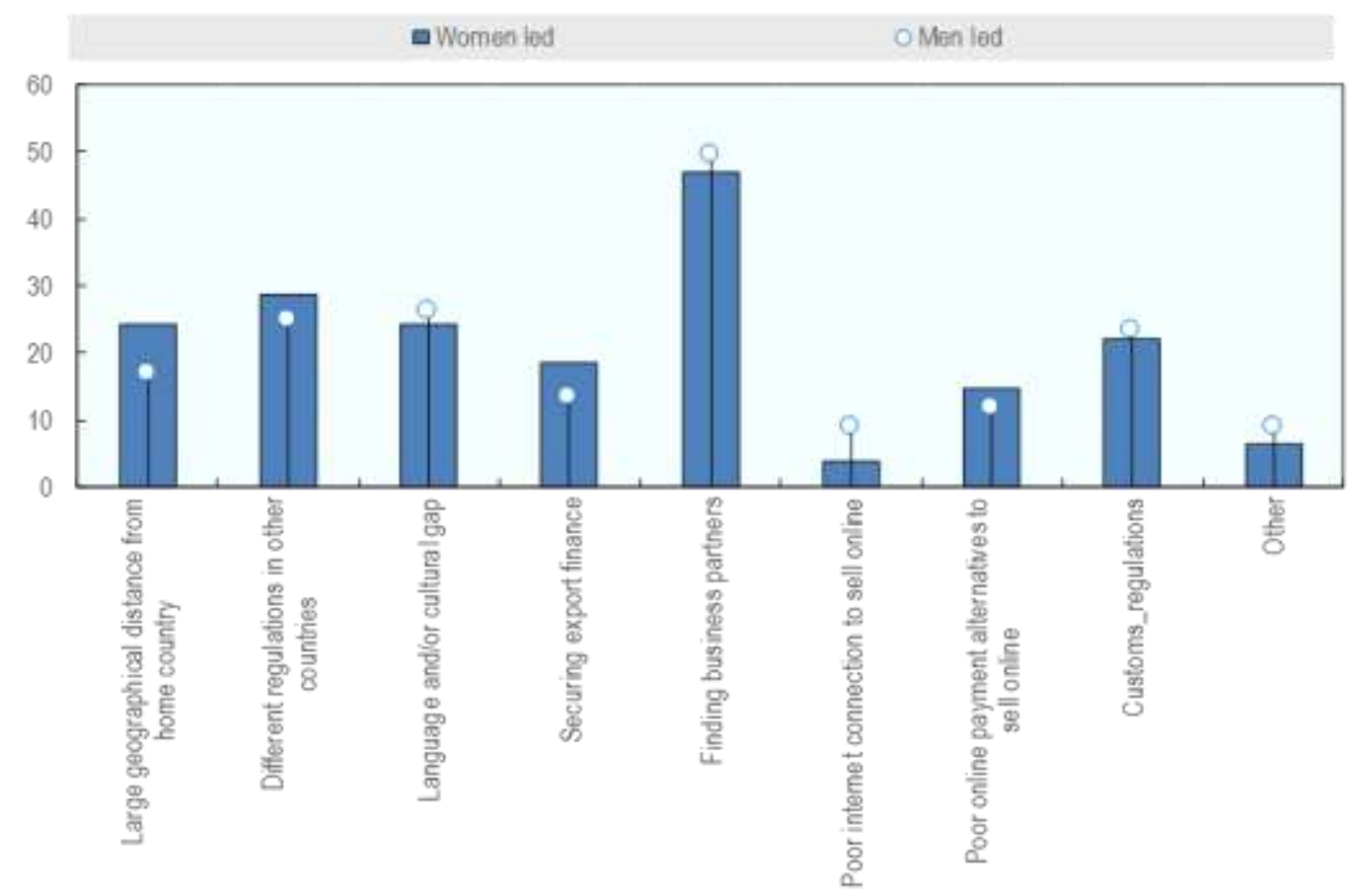

Note: Firms with a Facebook presence.

Source: Facebook-OECD-World Bank Future of Business survey, June 2019. 
Evidence from Canada suggests that women-owned firms may increasingly be engaging in international trade. Canadian women-owned SMEs have increased their export intensity between 2011 and 2017 on the extensive margin (share and number of exporting firms), but also on the intensive margin as a greater proportion of their revenues are derived from exports (Bélanger Baur, 2019). However, women-owned firms still account for a relatively small share of exporters overall in Canada.

Underlying this is the growing importance of the online presence of firms and their digital engagement with clients and suppliers. Both women-owned and men-owned SMEs engaging in e-commerce are more likely to export and import than their counterparts with no online presence (Suominen, 2018).

\section{Digital transformations will continue to impact women and men entrepreneurs differently}

Digital transformations have reduced the cost of engaging in international trade, facilitated the co-ordination of global value chains, helped diffuse ideas and technologies and connected more businesses to consumers globally (OECD, 2019d). Digitalisation has increased the scale and speed of trade and is changing how goods are traded. Digital transformations, and greater accessibility of information online, may particularly benefit small firms where women-led firms are prevalent. Since women-led firms are generally smaller than those led by men, they may particularly benefit from easier access to markets and the reduced trade costs associated with digital transformations and the rise in ecommerce (Box 2). Given that their enterprises often have access to less capital, they may also benefit particularly from access to digitally-enabled services rather than investing in fixed assets. Services sectors, where women work and lead businesses to a larger extent, may be particularly impacted by greater digitalisation which has given rise to new business models, and has contributed to the blurring of the distinction between goods and services. It also offers increased flexibility for women entrepreneurs, potentially allowing them to expand their businesses internationally. Greater digitalisation also comes with greater risks, however, in particular harassment, which women, including in a professional context, are more subjected to than men. Harassment discourages women from participating online, including in a professional context, which may dampen incentives to grow, including internationally. Greater digitalisation also increases returns to certain skills like engineering and information technologies where women are less present.

\section{Box 2. Leveraging trade in parcels for women entrepreneurs}

Today, many products ordered online are shipped across borders in individual consignments, in what is known as "trade in parcels". This type of trade is especially important for individuals and smaller firms, offering new opportunities to engage in trade whether as importers or exporters.

Ordering goods online and getting them delivered involves a complex network of interlinked actors and policies. This means that ensuring that parcels get to where they are needed requires policy action along a diverse set of issues. Digital platforms are, nowadays, one of the main gateways through which parcel trade is facilitated, connecting consumers with different businesses and providing the "plug-andplay" infrastructure that enables a streamlined shopping experience, including reviews, comparisons across products and the ability to make electronic payments. Once digitally ordered goods are ready to be dispatched, logistics providers, including express delivery companies, postal services, and freight forwarders take over (although increasingly the digital platforms are moving into this space). When parcels cross borders, it is the role of Customs authorities and other border agencies to manage traffic. This means enforcing trade rules, such as tariffs, but also undertaking health and safety, security and quality checks. 
Allowing women to more readily access international trade by means of parcel trade will require concerted efforts to continue to scale up the physical and regulatory infrastructure that underpins digital networks and the parcel ecosystem:

- Trade policies can help reduce the cost of access to the goods and services that underpin digital networks. Regulatory frameworks can also play a role in supporting an environment conducive to greater competition and lower costs of internet access, addressing digital divides.

- Ensuring that parcels get to where they are needed requires a range of policy actions, including logistics services liberalisation and at the border measures. Digital technologies can ensure that border processes are transparent and accessible to traders, and that formalities can be streamlined.

- Scaling up elements such as e-payments, digital certificates and signatures, and digital postal service capacities has the potential to enable a more efficient movement of parcels from producers to the border and from the border to consumers.

- Policy action in this area is especially important in the context of the COVID 19 pandemic where trade in parcels can be a lifeline for the activities of more vulnerable actors. More needs to be done to enable people to stay connected to markets, jobs and each other, including across borders. In the longer term, digital trade and associated digital technologies will also continue to be instrumental in supporting the wider economic recovery.

Sources: OECD (2020), Leveraging digital trade to fight the consequences of COVID-19, https://www.oecd.org/coronavirus/policyresponses/leveraging-digital-trade-to-fight-the-consequences-of-covid-19-f712f404/.

OECD (2020), Connecting businesses and consumers during COVID-19: Cross-border trade in parcels,

http://www.oecd.org/coronavirus/policy-responses/connecting-businesses-and-consumers-during-covid-19-trade-in-parcels-d18de131/.

OECD (2017), Digital Trade: Developing a Framework for Analysis, OECD Publishing, Paris, https://dx.doi.org/10.1787/524c8c83-en.

Trade in services, where many women work and where many women-led businesses operate, may increase due to digital transformations. Some services that were previously non-tradeable have become more easily tradable with greater digital capacity. Digital technologies have enabled "servicification", implying that the economy is increasingly relying on services: services are increasingly used to produce goods or to enhance manufacturing processes. Importantly, manufacturing firms are also increasingly bundling services with their core corporate offerings to provide additional value to customers ("servitisation") (OECD, 2017c).

Women-led firms use digital technologies extensively and they engage with clients online at least as much as men-led firms. ${ }^{33}{ }^{34} \mathrm{Among}$ businesses with a Facebook presence, women-led firms $(30.0 \%)$ obtained over half of their orders through e-commerce, comparable with men-led firms (29.5\%) (Figure 13).

\footnotetext{
${ }^{33}$ Since 2019, women have achieved gender parity as internet users in developed countries overall, defined as $+/-2 \%$ of internet users as compared with men (ITU, 2020). There are differences by region, however, with more women using the internet as compared to men in the Americas (1.01 women users as compared to men) and 0.94 women users for every man in Europe (ITU, 2020). Among OECD countries, gender gaps in internet use are highest in Turkey (12.8\%), Germany (5.8\%), Italy (5.3\%) and Japan (4.7\%) (Source: ITU, Gender ICT statistics, https://www.itu.int/en/ITU-D/Statistics/Pages/stat/default.aspx, accessed Dec. 1, 2020).

${ }^{34}$ Women perform slightly better in ICT skills than men in 30 OECD countries for which data is available and Russia (OECD, 2018c, p. 69). Returns to ICT skills are highest of all types of skills for both women and men, and are even higher for women than for men in both digital-intensive and non-intensive industries (OECD, 2018c, p. 72).
} 


\section{Figure 13. Share of home-country orders received through e-commerce}

By firms with a Facebook presence, by gender of owner/manager, $\%$

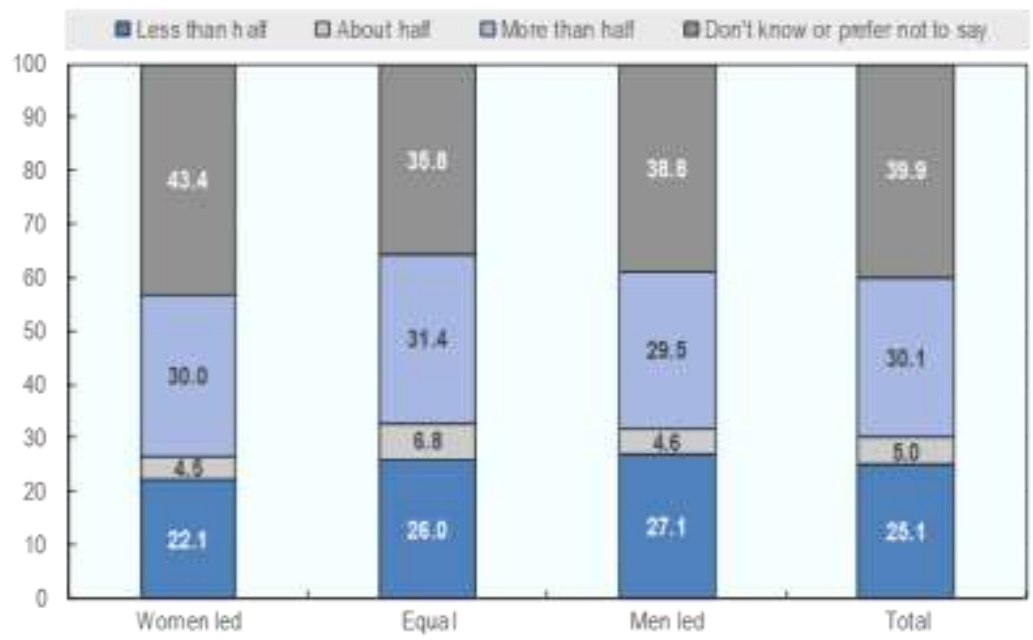

Source: Facebook-OECD-World Bank Future of Business survey, June 2019.

Operating online can offer a certain anonymity, for example, some online platforms hide the gender of sellers. There is some evidence that women-led firms operating online achieve similar performance to men-led firms possibly because the web can be more gender-blind (Suominen, 2018).

There are a number of reasons why women may prefer some online businesses: they often offer more flexibility in working hours; part-time work is more prevalent which appeals to women who may be combining work with domestic responsibilities, or supplementing their income from another part-time job; and start-up costs may be lower. Twenty-seven percent of drivers worldwide in the online driving service Uber are women; $30 \%$ of online service Lyft drivers are women (Cook et al., 2019). This compares with $4 \%$ of (offline) for-hire drivers that are women and $1 \%$ of medallion taxi drivers in New York City. ${ }^{35}$ The online services provide more information on potential clients, including the ability to track their accounts in case of a security-related incident, and the quasi-certainty of being paid, which may help to reduce risks for women drivers (Cook et al., 2019). Additionally, the online services require fewer initial capital outlays, in particular in comparison with medallion taxi drivers.

The digital transformation brings greater flexibility to work part-time, to work more flexible hours, and to work from home. All of these aspects are important to women who may have child-care responsibilities and generally spend more time on other domestic tasks. This may be particularly important for women entrepreneurs, some of whom have established their own businesses in order to be able to juggle multiple responsibilities as shown above. Digitalisation and video conferencing services have also reduced the need for face-to-face contact, which can reduce travel. When women have increased childcare and eldercare responsibilities, more flexibility in terms of time is an enabling factor in their entrance into entrepreneurship, and to them growing their businesses through trade. It may also mean, however, that more women entrepreneurs are flexibility entrepreneurs or sidepreneurs (Annex C, Box C.1), which are not necessarily the most productive firms nor those that have the greatest potential for survival.

Digital services may aid women entrepreneurs in overcoming some of the barriers they face in establishing and growing their businesses, and trading on international markets, such as accessing credit and obtaining information through professional networks. Some evidence indicates that increased objectivity due to

${ }^{35} \mathrm{https}: / / w w w . a m n y . c o m / t r a n s i t / m o r e-f e m a l e-c a b-d r i v e r s-b e h i n d-t h e-w h e e l-i n-n y c-1-11813917 / ;$ 
algorithm-driven decision-making in online credit agencies increases women entrepreneurs' access to finance (Biz2Credit, 2019), although if those algorithms are based on past lending practices, they may prolong past discriminatory lending patterns. Moreover, the web offers a huge amount of information on export procedures, and business opportunities. Some of this information was previously only available through professional networks and chambers of commerce, to which women have less access and cannot always leverage as well as men can, as outlined above. Although information can be accessed online, the mentoring and more individualised access to information, coaching and recommendation aspects of personal networking cannot be replaced by greater digitalisation.

Although greater digitalisation can bring many benefits to women entrepreneurs, an online presence also has greater risks for women. Between $28 \%{ }^{36}$ and $40 \%{ }^{37}$ of American adult individuals say they have been harassed online. The majority of those harassed are women, and women tend to be subjected to more severe types of harassment such as sexual threats, stalking and sustained periods of abuse. ${ }^{38}$ Younger people, in particular younger women, are particularly prone to receiving online abuse. Since women entrepreneurs are generally younger than men entrepreneurs, this may also affect them more.

Although the majority of harassment is sexist or political in nature, $24 \%$ of online harassment incidents are reported to be professional in nature. ${ }^{39}$ The online platform most used for abuse and harassment by far is Facebook ${ }^{40}$, which is also the online platform most used by small business owners and entrepreneurs. Online abuse incidents may discourage women from pursuing professional activity online or may discourage them from figuring prominently on their websites. Some choose to be represented by a male colleague or employee.

Finally, the digital transformation strongly increases returns to skills such as information technologies, engineering and mathematics. While the gender gap in non-specialist ICT skills is small in most OECD countries, men are more likely to be working in the platform economy and are four times more likely than women to be ICT specialists (OECD, 2017d). All-women entrepreneurial teams in the technology field are a small minority: $8 \%$ in the United Kingdom, $5 \%$ in France and 4\% in Germany (Boston Consulting Group, 2019).

Women are strongly under-represented in the high-risk, high-reward digital entrepreneurial space partly because girls are under-represented in science, technology, engineering and mathematics (STEM) studies, in particular in information technology, engineering and mathematics. ${ }^{41}$ Within the STEM categories, girls are more likely to study biology and medicine. Furthermore, when women who have studied STEM advance into careers, they often drop out of the IT industry which is dominated by men. Although not entirely clear, some experiences suggest that a macho work culture and long working hours that are incompatible with raising a family may be compelling reasons.

\footnotetext{
${ }^{36} 2018$ survey of Women Who Tech, Rad Campaign and Lincoln Park Strategies, http://onlineharassmentdata.org/

${ }^{37} 2014$ Pew Research Center study, https://www.pewresearch.org/internet/2014/10/22/online-harassment/

${ }^{38}$ Women's Media Center Speech Project, https://womensmediacenter.com/speech-project/researchstatistics?smid=nytcore-ios-share\# ftn1

392018 survey of Women Who Tech, Rad Campaign and Lincoln Park Strategies, http://onlineharassmentdata.org/

${ }^{40} 2018$ survey of Women Who Tech, Rad Campaign and Lincoln Park Strategies, http://onlineharassmentdata.org/

${ }^{41}$ Girls choose to opt out of IT, engineering and mathematics studies for a variety of reasons. One may be lack of women role models in these fields. Generally the decision to opt out of these fields is made by girls by age 13-14. Some organisations aim to create a "safe space" for girls to learn to code in an all-girl environment. Coding workshops for girls aged 7-12 are organised by She can code; code.org targets girls in grammar school. Another possible reason why most girls do not pursue STEM studies may be related to counselling. Girls strongly outpace boys in reading skills, and are on a par with them in mathematics. Guidance counsellors sometimes suggest that girls pursue areas in which they are strongest, i.e., literature and humanities, rather than areas in which they are ranked as well as boys, i.e. mathematics and sciences.
} 
New business models such as increased entrepreneurship that have been made possible by the digital transformations mean business relationships are not regulated by labour laws pertaining to the employeremployee relationship. Discrimination is not illegal outside employment relationships ${ }^{42}$ and harassment, including sexual harassment, that takes place outside the employment sphere, for example between an investor and an entrepreneur, is not covered by existing harassment legislation. Of the $44 \%$ of women in the technology sector who declared having been harassed, $77 \%$ of them indicated that it was in the context of funding drives; $65 \%$ of those sexually harassed reported being propositioned for sex in exchange for funding. ${ }^{43}$

\section{Conclusions}

Women-led firms are generally fewer, smaller, younger and less well financed than those led by men. They are more present in services sectors and in particular some sub-sectors that are not generally traded. Women often establish their businesses to pursue a passion or career goals, to ensure work/life balance, and to retain independence. Some women establish their businesses out of necessity, if they cannot find appropriate wage-employment or are unable advance their careers in a satisfactory way, including due to discrimination by employers, or to give themselves more flexibility in terms of working time.

Regardless of the size of the business and the broad sector of activity, women-led businesses with a Facebook presence trade less than their men-led counterparts. They tend to sell more to individual clients whereas those owned by men sell more to other businesses. However, a small number of women entrepreneurs are highly focused on growing their businesses internationally, and a small share of women-owned, mostly medium-sized businesses, export to more countries than their men-owned counterparts. The research points to a number of barriers to women's entrepreneurship and to growing their businesses and expanding into international trade. These include their difficulty to access credit and finance, the lack of time to devote to their businesses due to their disproportionate amount of unpaid work, reduced ability to travel and engage with remote clients, fewer networks and less experience in entrepreneurship. These barriers are not caused by trade or trade policies but they impact women's ability to afford themselves of the opportunities that trade brings in terms of economies of scale, greater competition that brings productivity gains, and learning-by-doing in new markets.

Trade policies and trade promotion initiatives that support smaller businesses and decrease information gaps particularly aid women entrepreneurs. Since women-owned firms tend to be smaller, they benefit even more than larger firms from the removal of barriers to trade, greater transparency in trade regulations and administrative processes and trade facilitating reforms, in particular the automation of border processes. Capacity building on trade rules through training of small-sized business owners has been shown to close information gaps. Regulatory frameworks that reduce the cost of internet access and that allow greater liberalisation of logistics services help smaller businesses more, and therefore women entrepreneurs. Scaling up of electronic payment services and digital certification systems and digitising postal services can also reduce costs and time spent in exporting for SMEs. Export promotion agencies in some countries support women entrepreneurs through initiatives such as organising information sessions on trade opportunities and trade procedures, and ensuring a gender balance when organizing missions abroad for exporters or potential exporters to international trade shows or in the context of trade agreements.

\footnotetext{
42 In a few OECD countries - Chile and Japan - even within the employer/employee relationship, there are no criminal or civil penalties for sexual harassment in the workplace, although in the case of Chile firm-level regulations establish sanctions for harassers which may consist of dismissal. In Japan, no legislation exists prohibiting sexual harassment in employment (World Bank, 2019).

${ }^{43}$ Women Who Tech and Lincoln Park Strategies, Tech and Startup Culture Survey, https://www.womenwhotech.com/wp-content/uploads/2017/08/WWTSurveyfinalAug15.pdf, August 2017.
} 


\section{Gender in Preferential Trade Agreements}

While women's economic empowerment hinges upon many factors, a large proportion of which are purely domestic, as was highlighted in the previous sections, trade policy and trade promotion can play a role in supporting more inclusive outcomes, including as regards women. Among the different policy approaches adopted by different countries to address gender equality issues, some countries have favoured the inclusion of gender-related provisions in preferential trade agreements (PTAs) as a tool for promoting women's economic empowerment, including through trade promotion and trade education and networking. According to Monteiro (2018), the number of gender-related provisions in PTAs has steadily increased. As of July 2020, 80 regional trade agreements, of which 69 are currently in force and notified to the WTO44, refer explicitly to women and to gender-related issues. These provisions have evolved and changed significantly over the years, although they still are quite general in nature and contain few binding commitments. The increased political momentum for trade and gender considerations was also reflected in the inclusion of stand-alone trade and gender chapters in some of the most recent or recently updated PTAs.

Additionally, there is a growing attention to the need to undertake gender-specific assessments of the impact of PTAs. In the context of governments' prior assessment of the impact of proposed policies and regulations on women ${ }^{45}$, the Government of Canada conducted in 2019 a gender-based analysis (GBA+) on a possible free trade agreement negotiated between Canada and Mercosur, and committed to subject more of its PTA negotiations to a GBA+ in the future ${ }^{46}$. Gender assessments are also increasingly included in the Sustainability Impact Assessments (SIA) undertaken by the European Commission when negotiating major trade agreements.

Finally, as public consultation and stakeholders' engagement gain ground in the process of developing trade agreements, ensuring the representation of women and consideration of the specific impacts on women is an area warranting specific attention.

A number of factors seem to have ushered this development (Zarrilli, 2017). In particular, the increasing number of women involved in policymaking and in international trade created new momentum, reinforced by the increasing awareness of the gender dimension of trade policy thanks to growing academic research and analysis. A decisive factor has been the realisation that trade can be instrumental to long-lasting development only if it is more inclusive and its benefits shared more widely.

Beyond the inclusion of gender-specific provisions, as noted in the previous sections, trade policies may further the role of women in trade through ostensibly gender-neutral provisions in economic areas with greater representation of women, or policy areas where cultural and legal barriers or regulatory inefficiencies appear to affect women more than men. For instance, PTA provisions on SMEs, the apparel and textile sector, or informal economic activities will impact women more because they are very numerous in these activities. Provisions addressing tariff and non-tariff barriers in key sectors for women-owned

\footnotetext{
${ }^{44}$ The sample of PTAs includes all those notified to WTO and in force; it does not include non-preferential agreements such as cooperation agreements. Of those only a couple predate 1990, but several entered into force between 1991 and 2001, although the coverage offered to gender issues remained limited. After a very slow progression between 2002 and 2015, the number of PTAs containing gender-related provisions and the breadth of coverage gained significant momentum from 2016, which also saw the emergence of the first dedicated gender chapters.
}

45 See for instance the approach of the European Commission, Austria, Belgium, Denmark, Finland and Sweden in https://eige.europa.eu/gender-mainstreaming/toolkits/gender-impact-assessment/examples-european-union

${ }^{46} \mathrm{GBA}+$ is "an analytical tool used by the Government of Canada to assess how diverse groups of women, men and non-binary people may be affected by domestic and international policies, programs, initiatives, organizations and activities (and) helps deliver on Canada's inclusive approach to trade". See https://cfc-swc.gc.ca/gba-acs/indexen.html and https://www.international.gc.ca/trade-commerce/gender equality-egalite genres/gba plus summaryacs plus resume.aspx?lang=eng 
businesses and in particular women-owned SMEs are also likely to have a significant impact. Measuring the impacts of such provisions bears further investigation, for example by means of gender-impact analysis.

PTAs can also play a role in promoting gender inclusiveness not only because of the potential influence, both positive and negative, of trade on women as workers, entrepreneurs or consumers, but also because trade policies and agreements can contribute to diffuse novel ideas and policy concepts beyond the jurisdiction where they first appeared. Countries may thus include gender-related provisions in their PTAs because they seek to ensure that they do not aggravate existing gender gaps. They can seek to improve gender-equalizing trends and ensure that women participate more widely and draw more benefits from international trade than is currently the case.

Finally, gender provisions in PTAs can also cross-reference the need to observe or reinforce other, nontrade, international commitments related to gender and women's economic empowerment, such as provisions that address non-discrimination in labour policies, signalling the importance of these issues internationally, and the need for policy coherence (Solís and Katada, 2009). Moreover, new provisions on human rights, the social dimension of sustainable development, or the protection of vulnerable groups are also likely to benefit women even if they include no explicit reference to them.

\section{Gender-related provisions in PTAs}

Gender provisions in PTAs can be classified in three broad categories ${ }^{47}$ :

- provisions reaffirming parties' existing commitments to gender equality;

- "safeguard" provisions meant to ensure that the PTA will have no adverse effects on gender equality; and

- provisions actively promoting gender equality and women's economic empowerment by incorporating gender-responsive policies or cooperation.

Although these three categories can be viewed as displaying gradually increasing ambition, the concrete effect they may have on women's economic empowerment will depend on a number of factors, including the extent to which they address the main gender-specific challenges for reaping the benefits of trade liberalisation. In particular, it is useful to explore whether gender provisions in PTAs focus or encourage national policies to focus on the seven drivers of transformation to address systemic barriers to women's economic empowerment identified by the UN Secretary-General's High-Level Panel on Women's Economic Empowerment (HLP-WEE). These are:

- tackling adverse norms

- ensuring legal protections and reforming discriminatory laws

- recognizing, reducing and redistributing unpaid work and care

- building assets - digital, financial and property

- changing business culture and practice

- improving public sector practices and procurement, and

- strengthening visibility, collective voice and representation.

While many of these drivers, such as the recognition of unpaid work and care, are clearly outside the realm of trade policy and, even more, trade agreements, strategic references in PTAs can contribute to raising the profile of those challenges among policy makers and serve as a basis for broader discussions among

\footnotetext{
47 The categorisation of gender-related provisions in PTAs was introduced by Lorand Bartels in International Trade Centre (2019); the classification in this note does not fully correspond to those categories as it follows a different set of criteria. See also Monteiro (2018).
} 
legislatures, domestic agencies in charge of gender-equality issues and stakeholders. Provisions reasserting existing - generally multilaterally agreed - commitments can focus on "soft law" objectives to promote gender equality and women's economic empowerment, or encompass legally binding obligations contracted by the Parties. Explicit acknowledgements of the importance of women's economic empowerment - whether or not in reference to the aim of promoting economic growth and sustainable development - are the most common gender-related provisions in PTAs. They are often found in preambles ${ }^{48}$ or in (sustainable) development chapters ${ }^{49}$ and the language used is quite general and largely aspirational. The instruments usually referenced include the UN Sustainable Development Goals in general, or specifically Goal 5 to "achieve gender equality and empower all women and girls" in a few agreements; the 2017 Buenos Aires Declaration on Women and Trade; the 1979 UN Convention on the Elimination of All Forms of Discrimination against Women (CEDAW); and the Rio Declaration on Environment and Development. Their most important merit is to increase the visibility of gender issues in the trade policy context.

Legally binding commitments reasserted in gender-related PTA provisions mainly concern relevant ILO Conventions (including No 100 on Equal Remuneration and No 111 on Non-Discrimination in Respect of Employment and Occupation) and other obligations the Parties may have contracted bilaterally concerning labour rights. Moreover, whether or not there is an explicit prohibition of gender discrimination in the workplace, this is part of the core labour standards taken up by most PTAs containing a labour chapter, including by reference to the 1998 ILO Declaration on Fundamental Principles and Rights at Work ${ }^{50}$. Labour rights commitments address some of the most important hurdles faced by women as workers. Although these provisions simply endorse existing obligations and do not create any new ones in the context of the PTA, they can be subject to the PTA's dispute settlement mechanism and, in some cases, their violation may trigger trade sanctions ${ }^{51}$. They thus appear both relevant and enforceable.

Provisions meant to ensure that the PTA will have no adverse effects on gender equality take the form of requirements to uphold domestic laws on gender equality and to promote corporate social responsibility (CSR). By virtue of these provisions, parties agree not only to avoid weakening the levels of protection in order to encourage trade and investment ${ }^{52}$, but also ensure that businesses do not infringe domestic laws or core standards to take advantage of new export opportunities or under pressure from foreign competition (International Trade Centre, 2019).

\footnotetext{
48 For instance, in the EU-ACP Partnership Agreement.

${ }^{49}$ For instance CPTPP Art.23.4 acknowledges the contribution women's enhanced participation to the domestic and global economy can make to economic development. The draft modernised EU-Mexico agreement (EU-Mexico), while not including gender-specific provisions, requires parties to "promote the development of international trade and investment in a way that is conducive to full and productive employment and decent work for all, in particular women (...)".

50 For instance? CPTPP Art.19.2, US-Peru Art.17.2, EU-Korea Art. 13.4.

51 See for instance US-Colombia Trade Promotion Agreement Art.17.2.1 and 21.2. The note in Art.17.2 specifies that "to establish a violation of an obligation under Article17.2.1 a Party must demonstrate that the other Party has failed to adopt or maintain a statute, regulation, or practice in a manner affecting trade or investment between the Parties." Similar provisions are found in other PTAs concluded by the United States.

52 See in particular the EU-Ukraine Association Agreement Art.290 “...right of Parties to establish and regulate their own levels of domestic (...) labour protection and sustainable development policies and priorities, in line with relevant internationally recognised principles and agreements, and to adopt or modify their legislation accordingly, (...) shall strive to continue to improve that legislation." and Art.296 "... shall not weaken or reduce the (...) labour protection afforded by its laws to encourage trade or investment, by waiving or otherwise derogating from (them) ... ", but also the proposed texts for the European Union's modernised agreements with Chile or Mexico.
} 
Commitments to core labour standards embedded in domestic regulation are often found in PTAs' labour chapters ${ }^{53}$ or chapters on sustainable development, although the modalities for implementing these standards domestically is in the hands of each party and not further specified in the PTA. More generally, these PTA provisions call for Parties to sustain and properly implement their existing domestic regulations, not for them to reform their regulations in favour of women's economic empowerment. Such provisions can oblige the different branches of signatory governments to review and monitor their legislation and its implementation. Moreover, they contribute to raising the profile of relevant laws, policies and practices. In addition, provisions that require parties to promote public awareness of these laws, policies and practices, whether specifically related to gender equality ${ }^{54}$, or more widely labour laws, ${ }^{55}$ help women overcome information challenges and provide advocacy for improving their position in the workplace and the market.

References to domestic policies on CSR seek to encourage businesses to take responsibility for implementing gender-positive norms, including the OECD Guidelines for Multinational Enterprises, the ILO Tripartite Declaration of Principles concerning Multinational Enterprises and Social Policy, ${ }^{56}$ or the UN Global Compact. ${ }^{57}$ Some PTAs require Parties to promote corporate social responsibility and accountability and encourage responsible business practices ${ }^{58}$, others simply reaffirm the importance of promoting such practices. ${ }^{59}$ Such provisions not only lend visibility to gender issues but also promote business accountability in advancing this policy agenda.

The most significant provisions in that category are "right to regulate" provisions, meant to ensure that domestic gender-supportive policies (including positive discrimination measures in favour of women) are sheltered from dispute under the agreement's liberalisation and non-discrimination provisions ${ }^{60}$. These take the form of exemptions and reservations listed by the parties to some of their PTA commitments, in particular in the area of government procurement, where public policies to support distressed areas or vulnerable populations are the most common. ${ }^{61}$ They may also qualify concessions made by the Parties in services areas so as to favour disadvantaged groups, although the only example of a provision that

${ }^{53}$ For instance, USMCA Art.23.9 calls parties to "implement policies (...) to protect workers against employment discrimination on the basis of sex (including with regard to sexual harassment), pregnancy, sexual orientation, gender identity, and caregiving responsibilities; provide job-protected leave for birth or adoption of a child and care of family members; and protect against wage discrimination."

54 For instance, the modernised Canada-Israel Free Trade Agreement (CIFTA) Art.13.1.7 "Each Party shall domestically promote public knowledge of its gender equality laws, regulations, policies and practices." Similar language in Canada-Chile Free Trade Agreement (CCFTA) Art.N bis 01.7, Chile-Uruguay Art.14.1.6, Chile-Argentina Art.15.1.6.

55 For instance, USMCA Art.23.10 and CPTPP Art.19.8.

56 The ILO Tripartite declaration of principles concerning multinational enterprises and social policy (MNE Declaration) is the ILO instrument that provides direct guidance to enterprises on social policy and inclusive, responsible and sustainable workplace practices.

57 The UN Global Compact is a voluntary initiative based on CEO commitments to implement universal sustainability principles and to take steps to support UN goals. The strategy of the UN Global Compact is to drive business awareness and action in support of achieving the Sustainable Development Goals by 2030. https://www.unglobalcompact.org/.

58 For instance, EU-Ukraine Association Agreement Art.422.

${ }^{59}$ For instance USMCA Art.14.17, CIFTA Art.16.4. In the latter, while gender provisions may, under certain conditions be subject to dispute settlement, the CSR provision is explicitly excluded.

${ }^{60}$ For instance EU-Mexico, where these "right to regulate" provisions are, in addition, subject to the specific dispute settlement mechanism of the Sustainable Development chapter.

61 See in particular the US Notes to the US-Colombia Trade Promotion Agreement Government Procurement Chapter ("This Chapter does not apply to preferences or restrictions associated with programs promoting the development of distressed areas, or businesses owned by minorities, disabled veterans, or women"). Similar provisions are included in US PTAs with Chile, Central America and the Dominican Republic, Morocco, Panama and Peru. 
makes explicit reference to gender in the context of the USMCA is the reservation to Mexico's commitments to open up the broadcasting sector ${ }^{62}$. "Right to regulate" provisions are critical for ensuring that other PTA provisions do not cause gender-positive action to backtrack, or for allaying concerns about the PTA's potential to aggravate existing gender gaps.

Provisions actively promoting gender equality and women's economic empowerment seek to enhance women's capacity to benefit from the opportunities created by the agreement. They mainly require parties to adopt gender-supportive policies, and promote cooperation to improve women's access to employment, education and decision-making, close information gaps and bolster social policies. One of the earliest and most explicit instruments establishing a concrete obligation to adopt affirmative action policies is the Southern African Development Community (SADC) Protocol on Gender and Development ${ }^{63}$. Other PTAs consider affirmative action, ${ }^{64}$ including as a possibility in the context of cooperation to promote equal opportunities ${ }^{65}$. Even in this category, there are no explicit obligations to enact specific policies, but rather targets to achieve ("enact laws ensuring equal access, benefit and opportunities to women and men", "make policies gender responsive", "promoting gender equality through, as appropriate, laws, regulations, policies and practices"), which lack definitions and specific milestones.

Provisions on cooperation to promote women's economic empowerment range from references to women or gender equality within other chapters of the PTA ${ }^{66}$ to cooperation principles ${ }^{67}$, to entire sections listing cooperation areas in considerable detail.68 A parallel can be drawn between these provisions and multilateral initiatives, such as APEC's Women and the Economy Forum (WEF) and Policy Partnership on Women and the Economy (PPWE) ${ }^{69}$, which have launched a dialogue on obstacles to women's access to capital and to markets, on the possible support for skills development, on the advancement of women into

62 "Concessions for indigenous social use shall be granted to indigenous people and indigenous communities of Mexico, with the objective to promote, develop, and preserve language, culture, knowledge, tradition, identity and internal rules that, under principles of gender equality, allow the integration of indigenous women in the accomplishment of the purposes for which the concession is granted."

63 Art.17 on economic empowerment requires Parties to "adopt policies and enact laws which ensure equal access, benefit and opportunities for women and men in trade and entrepreneurship, taking into account the contribution of women in the formal and informal sector (...) review their national trade and entrepreneurship policies to make them gender responsive (...) introduce measures to ensure that women benefit equally from economic opportunities, including those created through public procurement processes."

${ }^{64}$ For instance, CIFTA Art.13.1.6 ("affirm their commitments to promoting gender equality through, as appropriate, laws, regulations, policies and practices."). Similar language in CCFTA Art.N bis-01.6, Chile-Uruguay Art.14.1.5, ChileArgentina Art.15.1.5

65 See, for instance, the EU-Central America Association Agreement Art.47.1 ("Where appropriate, affirmative actions in support of women shall be envisaged.")

${ }^{66}$ For instance, USMCA Art.25.2 on Cooperation to Increase Trade and Investment Opportunities for SMEs calls, among others, for collaboration "to promote SMEs owned by under-represented groups, including women, indigenous peoples, youth and minorities, as well as start-ups, agricultural and rural SMEs, and promote partnership among these SMEs and their participation in international trade".

67 For instance, the EU-Ukraine chapter on Cooperation on employment, social policy and equal opportunities calls in Art.419 for "dialogue and cooperation on promoting the decent work agenda, employment policy, health and safety at work, social dialogue, social protection, social inclusion, gender equality and non-discrimination." and in Art.420 for pursuing "gender equality and ensure equal opportunities for women and men in employment, education, training, economy and society, and decision-making".

${ }^{68}$ As do all four of the PTAs containing gender chapters. See CIFTA Art.13.3.4, CCFTA N bis-03.4, Chile-Uruguay Art.14.3.4, Chile-Argentina Art.15.3.4

69 The WE brings together government authorities and the PPWE women entrepreneurs, academics and government officials to discuss gender issues https://www.apec.org/Groups/SOM-Steering-Committee-on-Economic-andTechnical-Cooperation/Working-Groups/Policy-Partnership-on-Women-and-the-Economy 
leadership roles in business, government, community and political levels, and on their better integration in scientific, innovation and technology sectors.

Cooperation in encouraging capacity building and skills enhancement of women at work and in business, promoting financial training, and improving women's access to, and participation and leadership in, science, technology and innovation could help address the skills mismatch that may thwart women's capacity to establishing and growing businesses, obtaining the necessary finance and accessing well-remunerated jobs. Cooperation in fostering women's representation in decision making and positions of authority in the public and private sectors, including corporate boards could ensure that women's needs and views are better taken into account and reinforce and expand women's currently shallower networks. Finally, cooperation with a view to conduct gender-based analysis, develop indicators to measure the impact of gender-responsive policies, strategies and actions supported by the PTA's cooperative activities $^{70}$, and share methods and procedures for the collection of gender-disaggregated data and the analysis of gender-focused statistics related to trade, could help inform policy making and ensure that the gender dimension is well understood and acted upon. However, these cooperation commitments lack the binding nature of commitments to core labour standards and to uphold domestic laws on gender equality, but rather denote statements of political intent. Parties can engage in them as they see appropriate and no milestones are set as to what such cooperation should achieve or by when. Their effectiveness in shifting policies and mentalities in favour of women's empowerment will depend on the countries' mutual interest for cooperation.

Most of the provisions in the three categories above have limited enforceability. This is not only because of their aspirational language that does not identify actions or omissions with a level of specificity sufficient to enable a challenge, but also because most of them are not subject to the dispute settlement mechanism of the agreement, with the exception of provisions in some of the labour chapters. As experience is gained about the implementation of those provisions, an ex-post assessment could provide valuable insights about their real impact in influencing policies and practices. In particular, an analysis of the nature and extent of implementation of gender provisions in existing PTAs and of the factors that seem to facilitate or hinder such implementation could provide valuable information to policy makers designing or enforcing accompanying domestic policies. In addition, the review of indirect effects of trade agreements in secondary and tertiary sectors where women tend to work or have businesses could provide further insights on the impact of those PTAs on women's economic empowerment.

\section{The specificities of dedicated gender chapters in PTAs}

To date dedicated trade and gender chapters are contained in four bilateral PTAs currently in force (ChileUruguay, ${ }^{71}$ Canada-Chile, Chile-Argentina, Canada-Israel), while two others (Chile-Brazil and ChileEcuador) have not yet entered into force. Although these chapters are also mostly couched in "best endeavour" language, they tend to be more specific in their endorsement of gender equality and non-discrimination between women and men. Their provisions reiterating parties' existing commitments are wider and more explicit than those found in PTAs not containing specific gender chapters, offering further detail about translating these endorsements into action. For instance, they include reference to the OECD Guidelines for Multinational Enterprises as regards corporate social responsibility for gender

\footnotetext{
70 For instance EU-Central America Art.47. 2. "Cooperation shall promote the integration of the gender perspective in all the relevant fields of cooperation, including public policies, development strategies and actions as well as indicators to measure their impact." See also the four PTAs with dedicated gender chapters (" $(g)$ conducting gender-based analysis; (h) sharing methods and procedures for the collection of sex-disaggregated data, the use of indicators, and the analysis of gender-focused statistics related to trade").

71 The Chile-Uruguay Agreement was the first to introduce a standalone trade and gender chapter in a bilateral agreement in 2016.
} 
equality, and "obligations under other international agreements addressing gender equality or women's rights to which (they are party)". While, as with other PTA provisions reaffirming the objective of gender equality, these provisions do not create obligations under the PTA, they are important as part of the agreement's context, object and purpose ${ }^{72}$ : other obligations under the agreement may also be interpreted in light of the parties' gender-related commitments.

Their most significant difference lies in the amount of detail they devote to cooperation activities and capacity building (in particular promotion of access to finance and women's entrepreneurship, development of women's networks, greater participation in decision-making positions in the public and private sectors); and the institutionalisation of monitoring the activities through the creation of a Trade and Gender Committee $^{73}$. An additional cooperation element worth highlighting is the reference to building capacity "including in non-government sectors". 74

The Trade and Gender Committee mandated in these chapters is in charge of determining and organizing the cooperation activities and exchange of information, discussing proposals to support policies and initiatives on trade and gender, considering matters related to the implementation and operation of the gender chapter, and making relevant recommendations to the PTA's Free Trade Commission. It may work with and encourage other bodies established under the agreement to integrate gender-related considerations, seek the advice of external experts or stakeholders and consider reviewing the trade and gender chapter to improve its effectiveness. The implementation of the cooperation activities is discretionary, as the chapters do not include a specific program, nor do they define budgets, baselines, targets, objectives, or measurements to monitor the cooperation. The Committee's role is consultative and it carries no power or authority. However, upon entry into force the Parties to these Agreements have developed a two-year evergreen work plan, ${ }^{75}$ including sharing policies and good practices more widely, ${ }^{76}$ collecting gender-focused statistics related to trade and women-owned businesses, and exchanging experience and best practices for conducting gender impact assessments.

As is the case of most of the gender-related provisions in other PTAs, the dedicated trade and gender chapters have limited enforceability and most are explicitly excluded from the PTA's dispute settlement mechanisms. The unique exception is to be found in the modernised Canada-Israel Free Trade Agreement (CIFTA), which allows the parties to have recourse to the dispute settlement mechanism established under the PTA, only if both consent and they have failed to resolve the matter through dialogue, consultations and cooperation. Having said that, the chapter mainly relates to cooperation activities and thus any matter that would arise under the chapter would naturally be dealt with through dialogue, consultations and cooperation. The other three agreements call on the parties to make efforts to resolve any issues through dialogue and consultations and explicitly prohibit them to avail themselves of the PTA's dispute settlement procedures.

\section{Mainstreaming gender provisions in PTAs}

Considering the gender provisions in PTAs in the light of the HLP-WEE drivers of transformation, all seven drivers are touched upon, in varying degrees. Ensuring legal protections and reforming discriminatory laws, changing business culture and practice, improving public sector practices and procurement and

\footnotetext{
72 Art.31 of the Vienna Convention on the Law of Treaties.

73 See CIFTA Art.13.4, CCFTA N bis-04, Chile-Uruguay Art.14.4, Chile-Argentina Art.15.4.

${ }^{74}$ See CIFTA Art.13.1.2, CCFTA N bis-01.2, Chile-Uruguay Art.14.1.2, Chile-Argentina Art.15.1.2.

75 See for instance the Canada/Chile work plan https://www.international.gc.ca/trade-commerce/trade-agreementsaccords-commerciaux/agr-acc/chile-chili/gender work-plan-travail genres.aspx?lang=eng.
}

${ }^{76}$ For instance, in the context of APEC. 
strengthening visibility, collective voice and representation, can be seen as assisted by provisions reasserting commitments, in particular in the field of labour, promoting CSR, "right to regulate" provisions, and provisions on cooperation. Tackling adverse norms (other than labour norms), recognizing, reducing and redistributing unpaid work and care, and building digital, financial and property assets has attracted little attention in PTA gender provisions, the exceptions being few references to non-discrimination on the basis of caregiving responsibilities ${ }^{77}$ and cooperation activities to promote "financial inclusion for women, including (...) access to finance"78. Moreover, most of the provisions being aspirational, whether the drivers of transformation will be tackled adequately depends on the political will of the PTA parties involved.

This assessment needs to be put in context, taking into account diverging negotiating priorities and views on gender-related policy among countries negotiating PTAs, as well as differences of view over the extent to which trade agreements are the vehicle for enforcing other commitments or addressing domestic policies related to cultural values, all of which can influence approaches to gender considerations. Gender related provisions are more common in PTAs negotiated between parties with similar levels of economic development, and are more wide-ranging in PTAs between parties experiencing a relatively high level of human development as measured by the Human Development Index (Monteiro, 2018), or in the context of wider economic partnership agreements, the remit of which goes well beyond strictly trade-related issues. That said, these efforts can still serve to create momentum for a gender perspective that goes beyond strictly economic considerations. As in the case of environmental and labour considerations, which are gradually earning a more central place within trade agreements, gender provisions in existing PTAs can influence the parties' and other governments' policy choices in the long run (Lopez et al., 2019). Raising the profile of trade and gender issues through PTAs could also encourage both civil society and the private sector to participate more broadly in the implementation of agreements (UNCTAD, 2017).

Some countries feel that the achievement of concrete policy results could be further promoted by mainstreaming gender provisions in the various thematic chapters of the PTA, as advocated in Canada's "two-pronged approach to trade and gender". ${ }^{79}$ This approach would entail including gender-specific provisions in other PTA chapters in the same vein as labour chapters or SME chapters incorporating provisions to promote employment equity and reduce the wage gap between women and men, or increase trade and investment opportunities for women-owned SMEs (Hughes, 2019). For instance it has been suggested that:

- Provisions dealing with government procurement could, in addition to the "right to regulate" provisions already present in some agreements, further encourage supplier diversity initiatives and training and certification programmes for women-owned and women-managed firms in partner countries (González, 2017[1]).

- Investment provisions could address intentional discrimination or unconscious bias against women investors by reinforcing CSR policies and by promoting gender balance in senior management and boards of directors of enterprises, and in investment arbitration (International Trade Centre (ITC), 2020[2]).

- Trade in services provisions could prohibit gender-based discrimination related to licensing and qualification requirements, which may de jure or de facto hinder women's capacity to engage in international trade. The Canadian proposal to the WTO Working Party on Domestic Regulation for a provision to ensure that domestic services regulations do not discriminate on the basis of

\footnotetext{
77 For instance USMCA Art.23.9.

78 See CIFTA Art.13.3.4, CCFTA N bis-03.4, Chile-Uruguay Art.14.3.4, Chile-Argentina Art.15.3.4.

${ }^{79} \mathrm{https}$ ://www.international.gc.ca/trade-commerce/gender equality-egalite genres/trade gender fta-alecommerce genre.aspx?lang=eng.
} 
gender ${ }^{80}$ aims to achieve this objective, although such a provision would need to take into account the parties' right to regulate. The distinction between PTAs, often with a much wider economic partnership remit, and multilateral trade rules is also relevant here. While the scope of the former is very broad, to date multilateral trade rules have largely focused on process disciplines on how regulations are made (transparent, non-discriminatory treatment as between countries or between foreign and national suppliers), rather than specifying what those regulations should be. Requiring a specific type of regulation is seen by some as a significant change.

- Technical barriers to trade provisions could encourage the development of gender-responsive norms and standards, in particular concerning product safety, by promoting the consideration of gender-differentiated outcomes of standards during the standards development process.

- Provisions on sanitary and phytosanitary measures could promote capacity building to improve small (and thus potentially women-owned) farmers' awareness and capacity to comply with rules and standards in export markets.

It has been argued that mainstreaming gender provisions could foster more specific policy commitments to complement any dedicated gender chapter in the PTA (Ala'l and Vargas Amaral, 2019). The dedicated gender chapter could in turn reinforce these specific provisions by supporting their interpretation in favour of gender equality and women's economic empowerment. Where chapters including mainstreamed gender provisions are subject to the PTA's dispute settlement mechanism, consideration could be given to gradually promoting the provisions' enforceability. This would also allow time to assess how compliance with such commitments would be assessed and by whom and what any appropriate penalty might be - all concerns that have been raised in the context of the application of trade dispute settlement to areas outside the expertise of trade policy makers.

\section{Gender impact assessments}

Gender-based analysis during the elaboration and negotiation of the PTA would greatly contribute in understanding the potential impact of the proposed agreement on women, in particular those at particular risk of being left behind. The incorporation of a gender-specific section in the upstream impact analysis would help identify potential positive and negative effects of the PTA; support identification and pursuit of trade reforms that have the potential to particularly benefit women (such as market access in certain sectors, trade facilitation, or measures to support SMEs or digital trade); support consideration of gender-related provisions; and identify areas for consideration for possible mainstreaming of gender responsive and inclusive provisions in the context of the negotiations and for providing assistance to help women take advantage of the new opportunities in the agreement.

Measuring impacts of different negotiating scenarios on women's and men's employment can inform trade negotiators as to who will be most affected by market access commitments. Devised as a gender impact analysis applied to all federal sectors and domains, Canada's GBA+ seeks to explore PTA impacts through a comprehensive quantitative and qualitative chapter-by-chapter analysis by asking what would be the expected socio-economic effects of the PTA on the country; which sectors would be particularly affected by the PTA and what is their gender composition; whether there would be important differential gender

\footnotetext{
80 In July 2017 Canada proposed that WTO Members commit to ensure that measures relating to licensing and qualification requirements and procedures do not discriminate on the basis of gender. See François-Philippe Champagne, Canada's Minister of Foreign Trade, at https://www.cigionline.org/articles/advancing-gender-equalitythrough-trade.
} 
effects that need to be managed; and what would be the trade policy measures and trade promotion initiatives that could address the differential effects ${ }^{81}$.

By contrast, EU's Sustainability Impact Assessment (SIA) was specifically developed to analyse the potential economic, social, human rights, and environmental impacts of ongoing trade negotiations, including trade-related gender analysis. SIA findings are also followed up by means of ex post evaluations of applied agreements. In both cases, such analysis needs to overcome scepticism about the relevance of gender considerations within trade policy; but also the scarcity of gender disaggregated data and the difficulty of interpreting them in a trade policy context. The publication of its outcomes helps both overcome the scepticism and improve the robustness of the analysis by seeking stakeholder feedback.

Recognizing that trade policy cannot address all potential impacts, a gender-specific prior impact analysis could also help identify what domestic policies and programs need to be developed or re-oriented to accompany and complement trade policy tools. Finally, any policy insights generated by gender impact analysis in the context of ongoing negotiations could be further supported if the effects of gender provisions in the PTA were monitored after the entry into force of the agreement and over time. The resulting information would help adjust policies and gradually improve the gender responsiveness of trade agreements and trade policy as well as trade promotion in general.

\section{Stakeholder engagement}

Stakeholder consultations before, during and after the elaboration of trade policies or the negotiations of trade agreements can be an important tool for incorporating gender perspectives, highlighting potential unintended negative effects and identifying promising paths for gender-responsive outcomes. Stakeholder engagement is an important process more generally, allowing to collect more diverse and well-informed inputs to best address the real needs of citizens, improving compliance by increasing the sense of ownership among stakeholders, and strengthening the accountability of public policies.

Many countries are modernizing their process for consultation and engagement moving from passive styles of consultation - such as posting texts online for comment - to a more proactive format to engage actively with a wider range of stakeholders using a broader range of tools, like workshops, town halls and roadshows. Engagement is becoming more systematic and more continuous, before, during and after the negotiation of agreements (OECD, 2019b).

Best practice in stakeholder engagement in the regulatory process suggests that governments should try to reach out to those who are usually less represented in the rule-making and policy-making processes (OECD, 2017e). There is a risk of regulatory capture of the engagement process by those who have enough resources to influence the process and time they can dedicate to ongoing consultations that might affect them. "Administrations must try to go beyond the 'usual suspects' and proactively search for an opinion of those who are either 'able but unwilling' or 'willing but unable' to participate in the public debate and make every possible effort to remove any obstacles for their participation" (OECD, 2017e). Some groups that are typically less represented in engagement processes are SMEs, new entrants and foreign stakeholders; women, who are less represented in industry networks and have less time to devote to

\footnotetext{
81 The GBA+ conducted on the Canada-Mercosur FTA negotiations estimated GDP, trade, and job and wage gains, income inequality, gendered impacts (concluding that the sectors projected to add more jobs - services, including retail/wholesale trade - would generate larger demands for women workers than for men), labour force participation, youth and SMEs. The chapter-by-chapter analysis found that the goods chapters could result in positive effects on women, with opportunities to seek further gender responsiveness provided the negotiating partners are willing; that the services, investment and government procurement chapters could be further strengthened to maximize positive effects on women; that the environment, labour, gender, SME and indigenous people chapters had the potential to result in improved participation and benefits for women; and that the institutional and dispute settlement chapters presented opportunities for enhancing gender responsiveness.
} 
networking may also need to be prioritised when engaging stakeholders. It is also important in particular to engage and involve stakeholders early in the policy-making process (OECD, 2017e).

Stakeholders can often provide some of the most informed opinions as to the potential impacts of proposed policies or agreements under negotiation and, thanks to the transparency of the process, can contribute to the credibility of proposed policies or agreements and to a wider buy-in from concerned constituencies. In addition to their function as a platform for gathering information, stakeholder consultations can close the loop by serving as a channel for ex post understanding of the impacts of policies, or the extent to which trade opportunities negotiated under agreements are being taken up and by whom.

Systems for engagement and consultation vary across countries and are often dynamic. Some are topdown driven, even legislatively mandated, setting out the process to be followed and establishing specific consultation mechanisms within government, with legislative bodies and with stakeholders from the private sector and civil society. Others are less formal and grow from bottom-up, e.g. initiated by demands from various stakeholder groups. There is always a risk that consultation will be dominated by vested interests and it is therefore important to ensure open, inclusive participation as well as representativeness. There is also often a reluctance on the part of policy makers to engage in what can often be an extended and sometimes contentious period of engagement. However studies have shown that such engagement often leads to improved outcomes in terms of regulatory effectiveness (Tamburrini et al., 2011).

To ensure the quality and comprehensiveness of outcomes, consultations need to be open, inclusive and transparent. Stakeholders from civil society organisations, businesses - both domestic and foreign, social partners (including trade unions), academia and national administrations can bring useful perspectives, both as groups directly affected or benefiting from proposed policy changes, and as actors working towards women's empowerment. Women's interest in trade negotiations derived from their roles as consumers, workers and business owners may be canvassed and advocated by consumer organisations, trade unions and business sector representatives respectively. It can be a challenge to ensure that women's perspectives and interests are prioritized and promoted among all the other legitimate interests that these organisations may have in a given trade negotiation.

In the context of these consultations, women's involvement is key to ensuring gender considerations are taken into account in trade policies and trade agreements. Women's organisations, or associations of women entrepreneurs and women-led businesses are particularly relevant because of the specific gender expertise and insights they can provide. Organisations representing women business owners in all signatory parties to the Canada-EU modernized trade agreement, for example, were consulted and engaged both in the phase of drawing up the agreement as well as during implementation and monitoring.

A range of tools can be used to seek gender perspectives on proposed trade policies via stakeholder consultations. The EU Handbook, for example, calls for a wide range of complementary activities, including interviews, interactive meetings and workshops, surveys of stakeholders, and dissemination of the initial policy questions and of the assessment's findings at all relevant stages through a dedicated website and other digital media. In the GBA+ undertaken in the context of its FTA negotiations with Mercosur, Canada sought feedback through a Canada Gazette notice of intent, a PlaceSpeak online platform, and a roundtable consultation with leading experts from various backgrounds.

In many cases, existing mechanisms for stakeholder consultation can be leveraged with a view to ensuring and promoting interests of women workers, consumers and entrepreneurs. In Chile, for example, the export promotion agency ProChile was leveraged to reach out and engage with women entrepreneurs that export in order to better understand the barriers they face and to better support women business-owners and exporters. Consultations with a gender perspective increasingly take place within different Ministries and government agencies and with the private sector, civil society and wider stakeholder groups in OECD countries. They are, for instance, central to Canada's GBA+ analysis of agreements under negotiations and to EU's Sustainability Impact Assessments (SIA) methods for collecting and proofing relevant information. 
In order to take into consideration women's needs and viewpoints, it is also necessary to ensure women are represented in decision-making, including when trade negotiations are undertaken. Teams of trade negotiators that are all-men or mostly men may tend to be less mindful of the impacts on women of the agreements they are negotiating.

\section{Conclusions}

In light of the challenges faced by women, the inclusion of gender-related provisions in trade agreements can play a role in promoting women's economic empowerment. An increasing number of PTAs incorporate provisions that aim to ensure that they do not aggravate existing gender gaps, that they improve women's participation in international trade and promote a more gender-balanced distribution of expected benefits. Although gender-related provisions in PTAs have been mainly aspirational, they can still increase the visibility of gender considerations in the context of trade policy and gradually generate momentum for wider and bolder approaches in future trade agreements. While views on gender-related policy and negotiating priorities still diverge among potential PTA parties, gender provisions in PTAs have evolved towards broader and more comprehensive provisions giving greater visibility to gender-related concerns, also reflected in the inclusion of dedicated gender chapters in some recent PTAs.

\section{An analytical framework for assessing and improving the gender responsiveness of trade policies}

\section{Why do a gender and trade review?}

Gender gaps in employment and labour market outcomes represent under-utilised areas of growth. Reducing the gap in labour participation rates between men and women by $25 \%$ would raise global GDP by 3.9\% in 2025 (ILO, 2017). Closing gender gaps at the country level opens the way for increasing national incomes through greater use of women's skills in the labour market. Gender gaps are widespread and multi-faceted and the policy actions undertaken to reduce them will also need to be so. Although domestic policy areas are often rightly prioritised, trade policies have a role to play in supporting and strengthening women's economic empowerment.

Members may wish to undertake trade and gender country reviews to help inform development of traderelated policies and regulations, or negotiation of trade agreements, in order to identify and address gender effects of trade. In addition to providing a framework within which to understand how trade impacts gender at the national level, including in terms of trade policies and possible commitments, the analytical framework suggested here allows to identify factors outside the realm of trade policies that influence the capacity of women to make the most of the opportunities trade can offer. Domestic policies need to work together with trade policy to ensure women can benefit from trade and trade agreements and it is important for trade policy makers to be aware of the need to liaise with their counterparts in government to advocate for appropriate action by the relevant authorities.

\section{How can a gender country review be used?}

This analytical framework could form the basis for country reviews to assist governments in consideration of their design of trade provisions and policies, allowing the benefits of trade to be widely shared. Countries may also wish to monitor gender-related trade policies or agreements ex post once they have gained some experience on their implementation. The following sets out a framework for such a country review which could be undertaken by the Secretariat for interested members subject to voluntary contributions. The framework could be further refined in the course of experience with a pilot review. 
Finally, Members may wish to use elements of the framework to feed into their WTO Trade Policy Reviews (TPR) in cases where they volunteer to include gender considerations. ${ }^{82}$ Including an assessment of some of the aspects of trade and gender outlined in this report in all TPRs would raise awareness of trade-related issues the women face in WTO member countries.

In the context of trade negotiations, gender country reviews can help inform consideration of priority areas for market access; help estimate likely impacts on women and men in terms of job losses and gains; and point to where further action will be necessary in terms of domestic policies to support a fuller realisation of the opportunities afforded through trade agreements. On the basis of a mapping at the country level of how women are impacted as consumers, workers and traders/entrepreneurs, policy makers can decide how to address potential gender gaps - through greater market access in products and sectors where women work and own businesses, through complementary domestic policies to offset negative impacts, or through policies that support women so they can fully reap the gains from trade. Such support mechanisms could also target specific demographics, such as indigenous women.

\section{Quantitative analysis of the impacts of trade on women}

Trade policies and trade agreements that provide greater market access in sectors in which women work and own businesses will allow them to engage more in international markets and reap the gains from trade. Conversely, policy-induced changes in sectors that stand to lose from import competition could impact the gender wage gap and women's participation in the labour force, if such policies affect sectors in which they work and lead businesses. Thus an important step is to identify which sectors are most affected by policy changes, both directly and indirectly. The design of trade policies and negotiation of trade agreements necessarily require trade-offs and often produce positive effects on some groups and negative effects on others. Analyses should consider the differential impact on men and women workers and entrepreneurs, so as to understand whether proposed provisions promote women's economic empowerment, or widen existing gender gaps, and whether complementary policies would be desirable to address these impacts. Trade will not necessarily reduce gender gaps in labour participation and entrepreneurship and understanding its policy impacts can also inform complementary policies necessary to address gender gaps. For this to take place, the availability of gender-disaggregated data is crucial.

Understanding the impact of trade on women workers, consumers and entrepreneurs can be a multipronged endeavour. One or more of the following aspects can be used to assess the impacts of trade on women. Firstly, impacts of trade on women's employment, wages and other job characteristics could be measured. Secondly, the extent to which women-owned businesses are participating in trade and the main barriers to trade affecting women entrepreneurs, could be evaluated. Third, price effects of trade policies could be assessed, as their impact on consumers can be substantial, particularly those in lower income quintiles where women are disproportionately represented.

\section{Assessing the impacts of trade on women's employment, wages and other job characteristics}

The first step in assessing how changes trade affects women's employment, wages and other job characteristics is clearly understanding where women work. This requires having access to appropriate gender-disaggregated data on employment of women and men engaged in import-competing and

\footnotetext{
${ }^{82}$ Since 2018, 18 WTO Members (53\%) have voluntarily included information on their gender responsive trade policies as part of their TPRs (out of 34 reviews conducted between January 2018 and September 2020). Five of these Members have dedicated specific chapters or sections on this issue and have mentioned the Buenos Aires Declaration. However, these have often been more of a vehicle for countries to showcase what they have done rather than an assessment of their progress in this area. Annex $F$ provides a checklist of areas of consideration for assessing and improving the gender responsiveness of trade policies.
} 
export-supported jobs, both directly and indirectly, by sector of activity. The OECD Trade in Employment dataset disaggregated by gender, combined with the Trade in Value Added (TiVA) data provides such data and is available over ten years for all OECD countries in a harmonised fashion.

Besides being at a highly aggregated level, the TiVA/TiM data do not provide information on genderdifferentiated wages or other job characteristics. Instead, these data are collected in many countries in labour force surveys. ${ }^{83}$ While they provide more granular information, data on wages and other job characteristics are not harmonised across countries, either in the questions asked, or in the way responses are aggregated, including within the OECD area.

Single-country analysis can often be undertaken using existing labour force survey data, or linked employer-employee data. ${ }^{84}$ Increasingly, linked employer-employee data are used for such studies since they provide detailed data that goes far beyond gender-differentiated employment. Such data is collected either through business registers and business statistics, or through business surveys (see Annex D outlining the comprehensive approach undertaken by Statistics Finland). They allow tracking of individuals across firms, across industries and between different employment statuses over time. Business survey and registry data are sometimes considered superior in quality to labour force surveys since the respondents are businesses rather than individuals and they may have greater incentives and ability to provide exact information, including precise classification of business sectors.

The fact that women tend to work more in services professions and that women-owned and women-led businesses are also more likely to be in services suggests that services sector data are particularly important in analyses of trade impacts on women. However, in many countries, including within the OECD, services sectors are not as well covered in business and labour force surveys.

In future, if members were interested in being able to draw out lessons from reviews across countries, micro-data collection would need to be harmonised, both in scope and frequency, and data would need to be aggregated in a harmonised fashion to the national population. In many countries, such harmonisation across different domestic data sources would increase the quality of the data used and therefore the analysis that uses it. Micro-data could be housed in a hub, and made available so that more comprehensive research could take place. A number of initiatives are underway to work toward this aim. The United Nations Committee on Business and Trade statistics has a program of work on gender that aims toward harmonized data collection and aggregation. The OECD Committee on Statistics and Statistical Policy has recently created a micro-data hub. In July 2020, the World Bank released the Gender Disaggregated Labour Database (GDLD) which harmonises household labour force surveys at the industry level for 138 countries, including 18 OECD countries. Variables include employment status, occupation and wages by broad industry category. ${ }^{85}$

At the micro level, issues of data confidentiality are substantial. As data becomes more granular, and individuals and firms could increasingly be identified, national statistical offices are less open to sharing their data. Although confidentiality issues can be resolved through digital means, trust in the institution hosting data will be key.

\footnotetext{
${ }^{83}$ Questions asked of individuals completing such surveys can include, in addition to their participation in the labour market, information on job search and employment transitions, education and skills, wages, part-time work, job security and type of employment contract, and other characteristics of their employment.

${ }^{84}$ Business surveys and linked employer-employee data are not however harmonised across countries either in their methodologies or in the scope of their questions making comparable studies of different countries challenging. The way in which various approaches that business survey data is aggregated to the level of the national population also impacts results.

85 https://development-data-hub-s3-public.s3.amazonaws.com/ddhfiles/858386/gdld-construction-paper-formatted0327.pdf
} 


\section{Box 3. Measuring impacts of policy changes}

Country reviews could also include analyses of impacts of recently adopted, or contemplated policies for reform, via modelling scenarios.

In order to analyse the impacts of trade on women's employment and other job characteristics, genderdifferentiated data are ideally integrated into modelled scenarios of trade policies. In the case of ex post analyses, actual impacts of trade policies ceteris paribus can be measured. Using micro data, researchers can conduct detailed analysis of the differential impacts of trade policies on various segments of the population, notably women. This usually takes the form of partial equilibrium analysis that provides access to granularity, but does not capture the interdependencies of economic outcomes. One way to do this is to integrate gender-differentiated data into a computable general equilibrium (CGE) model. Wide-ranging trade policies have complex, interactive outcomes that are best modelled in a comprehensive framework such as a CGE model. Such a framework requires detailed data, information and assumptions in areas such as gender-differentiated employment decisions, trade-offs between women's and men's employment, and gender-differentiated behaviours in responding to gains or losses in wages and employment opportunities.

A less integrated, but in many cases more accessible, way to undertake quantitative gender differentiated impact assessments is to model overall employment and wage outcomes of trade policy in a CGE context and use different approaches to measure gender impacts outside the model framework. One method is to use input-output tables to measure differential impacts on men and women according to the sectors in which they work. Input-output methodologies allow for modelling both direct and indirect impacts of trade policies, trade agreements and external events such as a global pandemic. Such an analysis could be undertaken using a CGE model such as the OECD METRO model combined with gender-differentiated employment data throughout the value chain such as TiVATiM.

While input-output data and CGE models are good at capturing the direct and indirect impacts of policy changes, they are often too aggregate to measure gender impacts. One way to capture the aggregate complexity of trade policy with the specific sector/gender impacts, is to combine CGE with micro data. This may include applying the CGE results to household survey data to further analyse the genderdifferentiated impacts.

Analytical strategies will be determined by factors such as the extent to which countries are exposed to trade, and the magnitude of changes brought on by the trade policy under review. The scope and methodology will need to be tailored to the country and type of agreement or policy under review.

\section{Impacts on women-owned businesses and MSMEs}

\section{A. Assessing barriers to trade for women-owned businesses}

In order to explore impacts of trade on women-owned businesses, it is necessary to understand the specific barriers faced by women-owned and women-led businesses in participating in trade. One way of obtaining some of this information is through surveys of business characteristics, including information on the owner or manager. ${ }^{86}$ One such survey is the Facebook-OECD-World Bank survey of businesses with a Facebook

86 One difficulty in comparing information on gender gaps in entrepreneurs is a lack of internationally accepted definition on what constitutes women- and men-owned firms. Furthermore, since some countries have created quotas for women-owned companies in their public procurement, a common definition of what constitutes a women-owned firm would make it easier for women-owned firms in other countries to participate in such tenders. Work is currently 
presence. ${ }^{87}$ Some countries have also undertaken surveys of their women exporters; one example is Chile's Radiografía Mujeres Exportadoras (ProChile and SUBREI, 2019). Such surveys can also take into account other demographic factors such as age, ethnicity, race and region of the business or businessowner.

A number of barriers to women's trade participation and entrepreneurship have been outlined in the preceding analysis and are further detailed in Annex C. Some of the most important include access to credit and financing, fewer and shallower networks, and more time spent on unpaid work thereby less time spent in paid employment and entrepreneurship. ${ }^{88}$ Such barriers are in part responsible for ongoing gender wage gaps, the scarcity of women in jobs at decision-making level and smaller size of women-owned businesses. However, the element of personal choice cannot be discounted: what should be assessed and addressed are the barriers impeding women's capacity to engage in labour markets and grow their businesses, should they choose to do so. The impact of these barriers to engagement in trade by women entrepreneurs and business owners can be tracked through surveys or, in some cases, existing statistics as discussed below.

\section{Access to credit and financing}

Collecting and harmonising data on credit approvals, credit guarantees, venture capital funding, angel investing and trade finance by gender would allow a more granular examination of access to credit and financing which constitutes a major barrier to women entrepreneurs growing their businesses, including internationally. Accessing and analysing gender-differentiated data on lending and acceptance rates by banks, credit agencies and export credit agencies, and investment decisions by investors, venture capital funds and angel investors would shed light on women's access to finance and credit. Many of these datasets are proprietary, however, and analysis using them is partial as it applies only to one institution. ${ }^{89}$

\section{Lack of time for paid employment and entrepreneurship}

Comparative statistics on unpaid work undertaken by women would be helpful to better understand differences both in labour force participation and in time spent in entrepreneurship. Time-use surveys measure how much time is spent by different members of a household on activities such as paid work, unpaid housework, childcare, eldercare, meal preparation, study, leisure time, personal care, sleeping and transport during a defined time period. ${ }^{90}$ Such information can inform to what extent women can participate in the labour force or entrepreneurship and have been particularly relevant in analysis of the impacts on women and men of restrictions of movement and school and childcare closures due to the COVID-19 pandemic. However, it should be noted that policies to remedy gender gaps in unpaid or domestic work, generally fall outside of trade policies. Domestic policies in the domain of parental leave and subsidised

underway by the International Trade Centre (ITC) and the Swedish Standards Institute (SIS) to propose and agree, with a wide range of partners, on the definition of a "Women Owned Business" and provide guidance on its use.

87 Another example is a survey by the International Trade Commission on services exporting firms in selected European countries and the barriers they face. The survey complements an earlier survey on firms in manufacturing and agriculture (International Trade Centre and European Commission, 2019).

${ }^{88}$ An overriding cultural and social barrier to women's economic empowerment which is more difficult to measure is unconscious bias. Most studies that attempt to estimate unconscious bias do so as a residual, which is an inadequate measurement. Finding appropriate instrumental variables for such a culturally specific and broad concept, however, is challenging so measuring unconscious bias will probably not be possible in the near future.

89 One dataset, Crunchbase, https://www.crunchbase.com/, has been used to document investments in entrepreneurial activity, including by gender of the entrepreneur Information is available on capital raised, investment rounds, education and other characteristics of the entrepreneur, portfolio of investors, and firm entry and exit (IPO).

90 In many countries, however, time-use surveys are not conducted on a regular basis. 
childcare may be important factors in ensuring women have access to the opportunities afforded by trade and trade agreements.

\section{Shallower business networks}

In a number of cases, support to women entrepreneurs in accessing international markets is provided by export promotion agencies, in particular with respect to the development of appropriate business networks. Assisting women in overcoming hurdles, facilitating their contacts and making information about exporting fully transparent and available can increase their capacity to export. The provision of training on business and financial management to women entrepreneurs, as undertaken by export promotion agencies in some countries, can also be a significant empowering factor. The impacts of such policies could be assessed in the context of a country review.

The model of existing PTAs setting up trade missions to provide contacts and financial support to small business owners and entrepreneurs is a good place to start, but such missions could be more gender-sensitive, e.g. by ensuring that women business owners are well represented ${ }^{91}$ or targeting women-owned businesses when allocating grants and low interest loans that aim to help MSMEs export. Some countries use the platforms afforded by PTAs to increase transparency regarding procedures to export and opportunities that those PTAs provide. These initiatives, if done well, can particularly support small businesses, among them women-led businesses. A country review could assess the efficacy of such policies for women-owned businesses.

\section{B. Assessing barriers to trade that particularly affect MSMEs}

Since women-owned businesses tend to be disproportionately small compared to those owned and led by men, the suite of trade policies and trade promotion efforts that support export-oriented women entrepreneurs overlaps strongly with policies to support MSME internationalisation. High trade barriers - non-tariff measures, overly cumbersome administrative procedures and burdensome rules of origin, inefficient trade infrastructure, lack of transparency regarding process, in addition to tariffs - affect both women and men entrepreneurs. However, as the removal of these barriers benefits small businesses even more than large ones, they are bound to be particularly profitable to women-led businesses, given their smaller size, lack of experience and shallower networks.

In particular, greater transparency in regulations and trade facilitating measures that improve firms' access to trade-related information and their ability to provide feedback on proposed regulations and practices, reduces their fixed costs and increases their propensity to trade. Moreover, trade facilitating reforms that reduce fees and charges and simplify and automate procedures applied at the border particularly benefit small businesses and encourage them to expand their export activities. The automation of the border process can be particularly important for women-led MSMEs, not only because it reduces the costs of processing documentation, but also because by dematerialising formalities it shelters women entrepreneurs from potential harassment and discrimination. Simplification of rules of origin is also crucial, since they are one of the most prevalent obstacles in sectors of relevance for women-led firms.

Assessing the administrative burden for firms of importing and exporting will shed light on barriers to trade that particularly impact women-owned and other micro- and small-sized firms. Indicators such as the OECD's Trade Facilitation Indicators ${ }^{92}$ give a snapshot of countries' trade facilitation performance. Indicators of information availability, streamlined procedures, automation and cooperation between border agencies are particularly important. These indicators are available for OECD and almost all non-OECD

\footnotetext{
${ }^{91}$ Some existing trade missions are women-only although there are differing views about such lack of diversity, which can appear to foster a "ghettoisation" of women-led firms.

${ }^{92}$ https://www1.compareyourcountry.org/trade-facilitation/en/0/all/default.
} 
countries thereby indicating areas where trade negotiations, reforms and cooperation activities may focus in order to ensure timely and less costly access to partners' markets.

\section{Assessing price effects of trade}

Trade and trade liberalizing reforms impact consumers by lowering prices and providing access to a wider variety of goods and services. Women are disproportionately represented in lower income quintiles and are therefore more strongly impacted by prices. Research suggests that different income quintiles seem to be affected similarly on an expenditure basis so in the first instance, the focus could be on where trade barriers raise prices and scope for trade liberalising reforms. ${ }^{93}$

Assessing trade impacts on prices is often done in a CGE context. ${ }^{94}$ Barriers to trade in goods and services that make up a substantial portion of household budgets could be prioritized. Moreover, staple foods are often more heavily taxed at the border and are more difficult to substitute in household consumption baskets and thereby effect more strongly the purchasing power of more vulnerable groups.

In a second stage, in order to further refine estimates of trade on more vulnerable groups, consumption patterns of the lowest quintile could be analysed in order to ensure that the products most consumed by those consumers are prioritized for market access. This would require detailed household budget data by income quintile, which is generally available in OECD countries. Lowering prices on goods consumed by the lowest income quintile in trading partners through greater market access can produce win-win outcomes.

In future, a more granular assessment of the price impacts of trade on women-led households would require data on household consumption by household composition, including the gender of the head of household and potentially also other demographics such as age, sub-national region, race and ethnicity. Such data, not available in most countries at present, would provide increased understanding of the differences in expenditure patterns which would in turn allow a more granular analysis of impacts of trade policies on women at different income levels and in different living situations. It could also be expanded to include an intersectional analysis of impacts on consumption of indigenous households, households of older women or men, or regional analyses.

While no evidence was found of 'regulatory discrimination' in the OECD area in terms of higher tariffs on goods destined to women, effective tariff rates on one product solely destined for women and girls (tampons and sanitary pads, which share a product classification - 961900 - with diapers) are high in some countries. These tariffs impact women and girls and families with very young children by raising consumer prices on goods that are of first necessity to those destined to buy them, even if they are a very small item in overall expenditure. This tariff line could be assessed and considered for priority market access.

\footnotetext{
93 The extent to which lower trade barriers will be passed onto consumers will depend on domestic economic structures, in particular competition. Awareness of the interaction between trade barriers and domestic economic structures will provide useful context to trade policy makers, even though these are not issues that can be addressed by them.

${ }^{94}$ Lower trade restrictions on goods and services offer substantial gains for consumers, in particular those in lower income categories where women are disproportionately represented. It should be kept in mind, however, that trade is only one part of the consumption story: about $40 \%$ of household expenditure is in non-tradables such as housing and is therefore not directly affected by levels of border protection.
} 


\section{Broad engagement to support women's economic empowerment}

Trade policies alone will not bridge the gender gaps. Many of the barriers that women entrepreneurs face to expanding internationally and establishing and growing their businesses go well beyond trade policies. The same can be said for women as workers and consumers, engaging effectively and productively in economic activity. Trade policy can only be part of a comprehensive strategy to increase women's economic empowerment and open the way for increasing national incomes through greater use of women's skills through the labour market.

A whole of government approach to women's economic empowerment necessitates engagement of trade policy makers with Ministries responsible for domestic policy areas in order to ensure coherence with, and support of, domestic policies. ${ }^{95}$ The main domestic policy areas that influence women's ability to compete internationally include policies that impact work/life balance; access to finance; access to STEM fields; tax systems; unconscious bias and access to networks; and ease of starting and closing businesses (see Annex E). A country review could prioritise areas for engagement that are outside the realm of trade policy.

\section{Ensuring gender balance in trade policy participation}

Stakeholder consultations can be an invaluable tool for incorporating diverse perspectives, identifying promising paths for gender-responsive outcomes and highlighting unintended negative effects. Existing consultation processes increasingly include gender perspectives and take place within different Ministries and government agencies with the private sector, civil society and wider stakeholder groups; these consultations can often provide some of the most informed expert opinions as to the potential impacts of proposed policies or agreements under negotiation. Within existing stakeholder consultation processes, such as consultations with consumer groups or business owners, gender perspectives should be an explicit criteria for inclusion. Moreover, it is necessary to ensure women are represented in decision-making, including when trade policies are developed. Teams of trade negotiators that are all men or mostly men may tend to be less mindful of the impacts on women of the agreements they are negotiating. A country review could include an assessment of the extent to which existing upstream and downstream consultation processes have incorporated gender perspectives and what more can be done to promote more inclusive stakeholder engagement, including by women.

\section{Box 4. Potential future impacts of COVID-19 on women}

The economic impact of COVID-19 over the medium to long term is difficult to measure but analyses indicate that it will be very substantial. Most studies suggest it will be significantly more than the 20089 global financial crisis, and its effects will be different. Earnings losses from job loss can be sustained over time: workers who lose jobs now forgo returns to experience and are likely to have less secure employment in the future. Effects are particularly severe when job losses occur in recessions (Davis and von Wachter, 2011). The consequences are not just limited to those who lose jobs, but also those who were about to enter the labour market for the first time (Alon et al., 2020). The economic consequences of sustained economic recession will affect everyone, but especially women who have less income to start with.

\footnotetext{
95 Much work has been done, and is ongoing, throughout the OECD on these questions and any further analyses of policy impacts on women would greatly benefit from inputs by area specialists. Much of the policy knowledge to date regarding gender gaps in education, employment, wages, unpaid work and entrepreneurship is summarized in OECD (2017b). A recent contribution by Lassébie et al. (2019) addresses access to finance by women entrepreneurs.
} 
Single parents will be particularly hard hit. They cannot rely on spousal income in case of job loss, and they are more at risk of not being able to continue their economic activity while children are at home. Three out of four single parent households are headed by a woman in the European Union; in the United States, four out of five single parents are women. Since women, particularly single women with children, are over-represented in vulnerable groups, they are more at risk during extended periods of downturn due to fewer resources to draw on and greater risk of job loss.

Women owned businesses may be particularly at risk of closure because they are less well capitalized and they are often in services sectors that cannot telework such as personal services and care services. Women have less access to financing and more often start businesses with very little capital (see section on Women entrepreneurs and business owners above and Annex C). In the United States, half of all women-owned businesses are concentrated in three industries: other services, including hair and nail salons and pet care businesses; healthcare and social assistance, including child day care and home healthcare services; and professional, scientific and technical services. Personal services and child and elder care services are proximity services that are likely to be closed during lockdown periods. As lockdowns persist, or there are periods of lockdown followed by re-opening followed by lockdown, these businesses may risk permanent closure, especially if they have less working capital at the outset.

However, some longer-term trends could potentially bring some benefits for women. Teleworking has been encouraged in many OECD countries and a substantial share of work in some countries has been done remotely during periods of confinement. For some, teleworking has been shown to be a viable business strategy, and can provide substantial gains to employers in terms of lower real estate costs and lower associated utilities costs. Savings can also extend to lower transportation costs for those that subsidize employees' transportation, and less need for canteen and other on-site services. Teleworking tends to be possible, however, for higher or middle income professions that do not require face-to-face contact. More flexibility in workplaces will be particularly positive for women who combine paid work with unpaid work and may boost their labour market participation. Less time spent commuting could also benefit women disproportionately as they are particularly time constrained. However, if more flexibility results in increased working hours and problems in separating work and personal life, the outcome could be less positive (OECD, 2017).

Cultural norms may also shift due to the COVID-19 crisis in the area of domestic, unpaid work. Women take on more unpaid work in households than men and spend more time taking care of children; and these tasks require more time during periods of sheltering-in-place. It appears likely that much of this uneven distribution of the burden of childcare persists during the current crisis: the factors that initially led to these arrangements, which could include relative income, relative bargaining power, and the influence of traditional social norms and role models, continue to apply (Alon et al., 2020). Current proportions of women:men participation in unpaid work ranges generally from 60:40 to 75:25 in OECD countries with relevant data (see section on unpaid work above and in Annex C). However, men's engagement in unpaid work is likely to increase although women will probably still take responsibility for the majority. If men increase their engagement in unpaid work, they may continue to do so to a certain extent due to factors such as learning-by-doing and a greater attachment with children. Some evidence indicates that paternal leave at birth has had a lasting effect of making men more engaged in childcare (Tamm, 2019)). The biggest impact on the division of labour among couples may occur where, during the COVID-19 crisis, the wife is in a critical occupation (such as medical doctor) while the husband is not (Alon et al., 2020). It can be assumed that the men in these households, which make up $9 \%$ of those in the United States, will become the primary caregivers. While this group is obviously a minority, it still consists of millions of households, suggesting that during the height of the crisis seeing men as the main providers of childcare will be more common than previously (Alon et al., 2020).

Some professions have increased their use of digital technologies due to remote working conditions imposed by COVID-19. Necessity has increased the digital skills of some professions that were 
relatively less digitally connected in some countries such as teachers. Teachers are overwhelmingly women and many have taken on new skills in order to respond to the demands of online education.

Source: Alon, Titan, M. Doepke, J. Olmstead-Rumsey and M. Tertilt (2020) The Impact of COVID-19 on Gender Equality, NBER Working Paper 26947, April. https://www.nber.org/papers/w26947.pdf; Davis, Steven J., and Till von Wachter. 2011. "Recessions and the costs of job loss." Brookings Papers on Economic Activity, no. 2:1-72; OECD (2017b), The Pursuit of Gender Equality: An Uphill Battle, OECD Publishing, Paris. DOI: http://dx.doi.org/10.1787/9789264281318-en; Tamm, Marcus. 2019. "Fathers' parental leave-taking, childcare involvement and labor market participation", Labour Economics 59:184-197. 


\section{References}

Ala'l, P., Vargas Amaral R. (2019), The Importance (and Complexity) of Mainstreaming Gender in Trade Agreements, Centre for International Governance Innovation, www.cigionline.org.

American Express (2019), The 2019 State of Women-Owned Businesses report, https://about.americanexpress.com/sites/americanexpress.newshq.businesswire.com/files/doc library /file/2019-state-of-women-owned-businesses-report.pdf

Amiti, M., S. J. Redding, and D.E. Weinstein (2019), "The Impact of the 2018 Tariffs on Prices and Welfare", Journal of Economic Perspective, 33(4): 187-210, DOI: 10.1257/jep.33.4.187, https://pubs.aeaweb.org/doi/pdfplus/10.1257/jep.33.4.187

Angelov, Nikolay \& Johansson, Per \& Lindahl, Erica, 2016. "Parenthood and the Gender Gap in Pay," Journal of Labor Economics, University of Chicago Press, vol. 34(3), pages 545-579.

Baldwin, J. and B. Yan (2015), Trade and Productivity: Insights from Canadian Firm-level data, Institute for Research on Public Policy, May 28, https://irpp.org/research-studies/trade-and-productivity/

Bamber, P. and C. Staritz (2016), The Gender Dimensions of Global Value Chains, International Centre for Trade and Sustainable Development (ICTSD), Geneva.

Bas, M. and C. Paunov (2019), What gains and distributional implications result from trade liberalization? Document de Travail du Centre d'Economie de la Sorbonne, UMR8174, March.

Bélanger Baur, A.A. (2019), Women-owned Exporting Small and Medium Enterprises: Descriptive and Comparative Analysis, Office of the Chief Economist, Global Affairs Canada, draft, 3 October.

Benz, S. and L. Johannesson (2019-03-18), "Job characteristics, job transitions and services trade: Evidence from the EU labour force survey", OECD Trade Policy Papers, No. 225, OECD Publishing, Paris, http://dx.doi.org/10.1787/bb21f81a-en

Berniell, M.I. and C. Sánchez-Páramo (2011), "Overview of Time-use data Used for the Analysis of Gender Differences in Time Use Patterns", Background paper for the 2012 World Development Report.

Biz2Credit, Women-Owned Business Study (2019), https://cdn.biz2credit.com/appfiles/biz2credit/pdf/asrevenue-of-women-owner-businesses-full.pdf

Black, S.E. and E. Brainerd (2004), "Importing Equality? The Impact of Globalization on Gender Discrimination", Industrial and Labor Relations Review, Vol. 57, No. 4, pp. 540-559.

Bloomberg (2018), "The 10 things everyone should know about women consumers", https://www.bloomberg.com/company/stories/top-10-things-everyone-know-women-consumers/, 11 January.

Bøler, E.A., B. Javorcik and K.H. Ulltveit-Moe (2018), Working across time zones: Exporters and the gender wage gap, Journal of International Economics, Vol. 111, March, https://doi.org/10.1016/j.jinteco.2017.12.008

Bøler, E.A., B. Javorcik and K.H. Ulltveit-Moe (2015), Globalization: A Woman's Best Friend? Exporters and the Gender Wage Gap, CEP Discussion Paper No 1358, June 2015, Centre for Economic Performance, London School of Economics and Political Science.

Borusyak, K. and X. Jaravel (2018), The Distributional Effects of Trade: Theory and Evidence from the United States, https://scholar.harvard.edu/files/xavier/files/borusyakjaravel jmp.pdf, 6 October, accessed 2 March 2020.

Boston Consulting Group (2019), Les inégalités d'accès au financement pénalisent les créatrices de startup : 1er barometre SISTA x BCG sur les conditions d'accès au financement des femmes dirigeant.e.s de startup, September 10, https://static1.squarespace.com/static/5cb5f6b651f4d41671cfdd25/t/5d77bf6b1c0c795f4311284b/156 8128879711/Barometre-SistaxBCG-France10sept.pdf, accessed 28 October 2019. 
Breschi, S., J. Lassébie and C. Menon (2018), "A portrait of innovative start-ups across countries", OECD Science, Technology and Industry Working Papers, No. 2018/02, OECD Publishing, Paris, https://doi.org/10.1787/f9ff02f4-en.

Broda, C., and D.E. Weinstein (2006), "Globalization and the Gains from Variety." Quarterly Journal of Economics 121 (2): 541-85. https://web.stanford.edu/ klenow/Broda and Weinstein.pdf

Brush, C. et al. (2014), "The Diana Report - Women Entrepreneurs 2014: Bridging the Gender Gap in Venture Capital", Babson College, https://www.babson.edu/media/babson/site-assets/contentassets/about/academics/centres-and-institutes/blank-institute/global-research/diana-project/dianaproject-executive-summary-2014.pdf

Brussevich, M. (2018), "Does trade liberalization narrow the gender wage gap? The role of sectoral mobility," European Economic Review, Vol. 109, October, https://doi.org/10.1016/j.euroecorev.2018.02.007

Burk, D.L. (2018), Bridging the gender gap in intellectual property, WIPO Magazine, April, https://www.wipo.int/wipo magazine/en/2018/02/article 0001.html

Cerina, F., Moro, A. and Petersen Rendall, M. (2017), "The Role of Gender in Employment Polarization", Department of Economics Working Paper, No. 250, University of Zurich.

Charbonneau, K. (2019), "The Impact of a Trade War: Assessment of the Current Tariffs and Alternative Scenarios", Bank of Canada Staff Analytical Note, https://www.bankofcanada.ca/wpcontent/uploads/2019/07/san2019-20.pdf

Cook, C., et al. (2019), "The Gender Earnings Gap in the Gig Economy: Evidence from over a Million Rideshare Drivers", 8 March, https://web.stanford.edu/ diamondr/UberPayGap.pdf.

CSLS (Centre for the Study of Lining Standards) (2018), "Rising Import Competition in Canada and its Employment Effect by Gender: Evidence from the 'China Shock", CSLS Research Report 2018-3 Ottawa, August 2018.

Der Boghossian, A. (2019), Trade Policies Supporting Women's Economic Empowerment: Trends in WTO Members, World Trade Organization Economic Research and Statistics Division, Staff Working Paper ERSD-2019-07, 20 May.

Dixit, A.K. and J.E. Stiglitz (1077), "Monopolistic Competition and Optimum Product Diversity" American Economic Review, June 1977, 67(3), pp. 297-308.

Doepke, M. and M. Tertilt (2016), "Families in Macroeconomics.", Chapter 23 of Handbook of Macroeconomics, Vol. 2., Elsevier, North Holland.

ECLAC (Economic Commission for Latin America and the Caribbean) (2019), "Women's autonomy in changing economic scenarios", United Nations, Santiago.

Ernst and Young (2013), It's who you know: women entrepreneurs and the impact of networks, https://www.ey.com/Publication/vwLUAssets/EY Its who you know Women entrepreneurs and th e impact of networks/\$FILE/EY-Its-who-you-know-Women-entrepreneurs.pdf

European Commission (2010), 2009 Eurobarometer Survey on Entrepreneurship, Directorate-General for Enterprise and Industry, June 4.

European Parliament (2018), Report on Gender Equality in EU Trade Agreements, Committee on International Trade and Committee on Women's Rights and Gender Equality.

Fajgelbaum, P. and A. Khandelwal (2016), "Measuring the Unequal Gains from Trade," The Quarterly Journal of Economics, Vol. 131.

Feyrer, J. (2009), Trade and Income - Exploiting Time Series in Geography, NBER Working Paper 14910 http://www.nber.org/papers/w14910.

Fitzgerald, O. (2019), Why Negotiations Should Take a Whole Agreement Approach to Mainstreaming Gender in Trade Agreements, Centre for International Governance Innovation, www.cigionline.org. 
Frankel, J.A. and D.H. Romer (1999), "Does Trade Cause Growth?", American Economic Review, Vol 89 (3): 379-399, DOI: 10.1257/aer.89.3.379.

Furman, J., K. Russ and J. Shambaugh (2017), US tariffs are an arbitrary and regressive tax, VoxEU column, 12 January 2017. Available at: http://voxeu.org/article/us-tariffs-are-arbitrary-and-regressive$\underline{\operatorname{tax}}$

Gailes, A., Gurevich, T., Shikher, S., and Tsigas, M. (2018) Gender and Income Inequality in United States Tariff Burden, US International Trade Commission working paper 2018-08-B, August, https://www.usitc.gov/publications/332/working papers/gender tariff 1.html

Goldin, C. (2014), "A Grand Gender Convergence: Its Last Chapter", American Economic Review 2014, 104(4): 1091-1119, http://dx.doi.org/10.1257/aer.104.4.1091

Goldstein, M., P. Gonzalez Martinez and S. Papineni (2019), "Tackling the Global Profitarchy: Gender and the Choice of Business Sector", World Bank Policy Research Working Paper 8865, May.

Gonzalez, Arancha (2017), Public Procurement, a Tool to Boost Women's Economic Empowerment, Speech delivered by ITC Executive Director Arancha Gonzalez at Scuola di Politiche, Milano, 10 November 2017, http://www.intracen.org/news/Public-Procurement-a-Tool-to-Boost-WomensEconomic-Empowerment/

Gurevich, T, Riker D and Tsigas M (2020): Trade Policy and Gender: Examination of Gender and SectorSpecific Outcomes. Presented during the 23rd Annual Conference on Global Economic Analysis (Virtual Conference), 2020. www.gtap.agecon.purdue.edu/resources/download/9773.pdf

Gurevich T and Riker D (2018), "Exporting and Gender Earnings Differentials in the U.S. Manufacturing Sector", Economics Working Paper Series. Working Paper 2018-11-A, US International Trade Commission, Washington DC.

Hamilton, D. and C. Atkinson (2017), Optimizing the internet for more inclusive trade, online article dated 27 October 2017. Available at www.tradeforum.org/news/Optimizing-the-internet-for-more-inclusivetrade/

He, Z. (2017), "Trade and Real Wages of the Rich and Poor : Cross-Country Evidence." Working Paper, https://www.wto.org/english/news e/news17 e/he stud 14sep17 e.pdf, accessed March 2, 2020.

Hochberg, Y., A. Ljungqvist and Y. Lu (2007), "Whom you know matters: Venture capital networks and investment performance", The Journal of Finance, Vol. 62, No. 1, February, https://www.cis.upenn.edu/ mkearns/teaching/NetworkedLife/VC networks.pdf

Horvát, P., C. Webb and N. Yamano (2020), "Measuring employment in global value chains", OECD Science, Technology and Industry Working Papers, No. 2020/01, OECD Publishing, Paris, https://doi.org/10.1787/00f7d7db-en.

Hottman, C.J, and R. Monarch (2018), "Estimating Unequal Gains across U.S. Consumers with Supplier Trade Data," Board of Governors of the Federal Reserve International Finance Discussion Paper no. 1220, https://www.federalreserve.gov/econres/ifdp/files/ifdp1220.pdf, January. [accessed March 2, 2020].

HSBC Private Banking (2019), She's the Business: Supporting Entrepreneurial Spirit, https://www.hsbcprivatebank.com/en/discover/our-insights/she-is-thebusiness?cid=PBSEC:EB:NA:S0:PB:L15:XXG:XTR:0:XX:13:0919:001:STB19

Hughes, V. (2019), Gender Chapters in Trade Agreements, Centre for International Governance Innovation, www.cigionline.org

IMF (2017), "Making Trade an Engine for Growth for All: the case for trade and for policies to facilitate adjustment," for discussion at the meeting of G20 Serpas, March 23-24, https://www.imf.org/en/Publications/Policy-Papers/lssues/2017/04/08/making-trade-an-engine-ofgrowth-for-all

International Labour Organization (ILO) (2018), Global Wage Report 2018/19: What lies behind gender pay gaps, International Labour Office, Geneva. 
International Labour Organization (ILO), (2017), "World Employment Social Outlook - Trends for women 2017", International Labour Office, Geneva.

International Labour Organization (ILO), (2016), "Closing the gender pay gap: a review of the issues, policy mechanisms and international evidence", by Jill Rubery and Aristea Koukiadaki, International Labour Office, Geneva.

International Labour Organisation and World Trade Organisation (ILO/WTO, 2017), Investing in Skills for Inclusive Trade, https://www.ilo.org/wcmsp5/groups/public/---ed emp/--ifp skills/documents/publication/wcms 561536.pdf

International Trade Centre (2020), Mainstreaming Gender in Free Trade Agreements, ITC Geneva,

International Trade Centre and European Commission (2019), From Europe to the World: Understanding Challenges for European Businesswomen, http://www.intracen.org/publication/Europe-to-world/.

Jaravel, X and E. Sager (2019), 'What are the Price Effects of Trade? Evidence from the U.S. and Implications for Quantitative Trade Models'. London, Centre for Economic Policy Research. https://cepr.org/active/publications/discussion papers/dp.php?dpno=13902

Juhn, C., G. Ujhelyi and C. Villegas-Sanchez (2014), "Men, women, and machines: How trade impacts gender inequality", Journal of Development Economics, Vol. 106, pp. 179-193.

Jung, O. (2010), Small Business Financing Profiles: Women Entrepreneurs, SME Financing Data Initiative, Industry Canada, https://www.ic.gc.ca/eic/site/061.nsf/vwapj/ProfileProfil Oct2010 eng.pdf/\$file/Profile-Profil Oct2010 eng.pdf, October.

Keller, W. and H. Utar (2019), Globalization, Gender and the Family, manuscript dated June 27.

Klyver, K., S. Nielsen and M. Evald (2013), "Women's self-employment: An act of institutional (dis)integration? A multilevel, crosscountry study", Journal of Business Venturing, Vol. 28 (4).

Korinek, J. (2005), "Trade and Gender: Issues and Interactions", OECD Trade Policy Papers, No. 24, OECD Publishing, Paris. DOI: http://dx.doi.org/10.1787/826133710302

KPMG, Mind the gap: Culture change and the gender pay gap, https://home.kpmg/ie/en/home/insights/2018/03/gender-pay-gap.html

Krugman, P.R. (1979), "Increasing Returns, Monopolistic Competition, and International Trade." Journal of International Economics, Nov. 1979, 9(4).

Kutlina-Dimitrova, R-C., F. Amores and V. Román (2018), "How Important are EU Exports for Jobs in the EU?", Chief Economist Note, Issue 4, November.

Lassébie, J., et al. (2019), "Levelling the playing field : Dissecting the gender gap in the funding of startups », OECD Science, Technology and Industry Policy Papers, n 73, Éditions OCDE, Paris, https://doi.org/10.1787/7ddddd07-en.

Levinson, M. (2016), "Job Creation in the Manufacturing Revival", Congressional Research Service, Washington, DC.

Lindroos P, H. Luomaranta and S. Nurmi (2019), "The role of gender in trade -statistical evidence from linking Finnish microdata on employees and entrepreneurs", Statistics Finland, 2019.

Lopez, D., F. Muñoz and J. Cáceres (2019), Gender Inclusion in Chilean Free Trade Agreements, economiayempresa.udp.cl/wp-content/uploads/2019/05/003lopez.pdf.

Lopez, D., and F. Muñoz (2018), Trade Policy and Women in the Pacific Alliance, Agenda Internacional Año XXV, № 36.

López, R.A. (2016), "Are Export Subsidies Good for Women? Micro Evidence from a Quasi-Natural Experiment", International Business School, Brandeis University, 16 October 2016. 
Luomaranta H, Cantu F, MacFeely S, and Peltola A (2020), The role of multinational and trading enterprises in the gender pay gap: Evidence from Finland. United Nations Conference on Trade and Development (UNCTAD)

McKinsey Global Institute (2015), The power of parity: How advancing women's equality can add $\$ 12$ trillion to global growth, McKinsey \& Company, September 2015.

Menon, N. and Y. van der Meulen Rodgers (2009), "International Trade and the Gender Wage Gap: New Evidence from India's Manufacturing Sector", World Development, Vol. 37, No. 5, pp. 965-981.

Mion, G and L. Linke Zhu (2013), "Import competition from and offshoring to China: A curse or blessing for firms?', Journal of International Economics, 2013, vol. 89, issue 1, 202-215.

Miroudot, S. and C. Cadestin (2017), "Services In Global Value Chains: From Inputs to Value-Creating Activities", OECD Trade Policy Papers, No. 197, OECD Publishing, Paris, https://doi.org/10.1787/465f0d8b-en.

Monteiro, José-Antonio (2018), Gender-related Provisions in Regional Trade Agreements, World Trade Organization Economic Research and Statistics Division, Staff Working Paper ERSD-2018-15, 18 December, https://www.wto.org/english/res e/reser e/ersd201815 e.pdf

National Board of Trade Sweden (2020), "Trade and Gender Equality - The role of trade policy" , Stockholm.

National Board of Trade Sweden (2019), "Trade and Gender Gaps - Can trade policy contribute to gender equal value chains?" Stockholm, June.

National Board of Trade Sweden (2017), Trade and social sustainability: An overview and analysis, October, Stockholm.

National Board of Trade Sweden (2011), Gender impacts of international trade and trade policy - A case study of the FTA between Korea and the EU, March, Stockholm.

National Women's Law Center (NWLC) (2016), National Snapshot: Poverty among women and families, 2015, Fact Sheet, by Jasmine Tucker and Caitlin Lowell, September, https://nwlc.org/wpcontent/uploads/2016/09/Poverty-Snapshot-Factsheet-2016.pdf

New York City Department of Consumer Affairs (2015), From Cradle to Cane: The cost of being a female consumer, a study of gender pricing in New York City, https://www1.nyc.gov/assets/dca/downloads/pdf/partners/Study-of-Gender-Pricing-in-NYC.pdf

Nielsen, S., K. Klyver and M. Evald (2010), “Denmark”, in: Fielden, S. and M. Davidson (eds.), International Research Handbook on Successful Women Entrepreneurs. Edward Elgar, Cheltenham.

Nordås, H.K., M. Lodefalk and A. Tang (2019), "Trade and jobs: a description of Swedish labor market dynamics," Working Papers 2019:2, Örebro University, School of Business.

OECD (2021), "The OECD Services Trade Restrictiveness Index: Policy Trends up to 2021", January, https://www.oecd.org/trade/topics/services-trade/documents/oecd-stri-policy-trends-up-to-2020.pdf

OECD (2020a), Services trade and labour market outcomes. Synthesis report, March 2020.

OECD (2020b), Services trade and labour market outcomes in the United Kingdom, June 2020.

OECD (2020c), Mapping Trade to Household Budget Survey: a conversion framework for assessing the distributional impact of trade policies, TAD/TC/WP(2020)11/FINAL, 1 December.

OECD (2019a), Multinational Enterprises in Domestic Value Chains, OECD Science, Technology and Industry Policy paper no. 63, https://www.oecd-ilibrary.org/science-and-technology/multinationalenterprises-in-domestic-value-chains 9abfa931-en.

OECD (2019b), Trade Policy Brief: Engaging and consulting on trade agreements, October.

OECD (2019c), OECD SME and Entrepreneurship Outlook 2019, OECD Publishing, Paris, https://doi.org/10.1787/34907e9c-en

OECD (2019d), Trade Policy Brief: Digital Trade, https://www.oecd.org/trade/topics/digital-trade/, 
October.

OECD (2019e), Services Trade and Labour Market Adjustments: A Description of Swedish Labour Market Dynamics, Case Study, May 2019.

OECD (2018a), OECD Reviews of Digital Transformation: Going Digital in Sweden, OECD Publishing, Paris. http://dx.doi.org/10.1787/9789264302259-en

OECD (2018b): Women in Global Value Chains, 2018, https://www.oecd.org/sdd/its/Women-in-GVCs.pdf

OECD (2018c) Bridging the Digital Gender Divide: Include, Upskill, Innovate, http://www.oecd.org/digital/bridging-the-digital-gender-divide.pdf

OECD (2017a), "Making trade work for all", OECD Trade Policy Papers, No. 202, OECD Publishing, Paris. DOI: http://dx.doi.org/10.1787/6e27effd-en

OECD (2017b), The Pursuit of Gender Equality: An Uphill Battle, OECD Publishing, Paris, DOI: http://dx.doi.org/10.1787/9789264281318-en.

OECD (2017c), OECD Digital Economy Outlook 2017, OECD Publishing, Paris. http://dx.doi.org/10.1787/9789264276284-en

OECD (2017d), Entrepreneurship at a Glance 2017, OECD Publishing, Paris, https://doi.org/10.1787/entrepreneur aag-2017-en

OECD (2017e), OECD Best Practice Principles on Stakeholder Engagement in Regulatory Policy, Draft for Public Consultation, http://www.oecd.org/governance/regulatory-policy/public-consultation-bestpractice-principles-on-stakeholder-engagement.htm.

OECD-European Union (2017), The Missing Entrepreneurs 2017: Policies for Inclusive Entrepreneurship, OECD Publishing, Paris. http://dx.doi.org/10.1787/9789264283602-en

OECD-European Union (2016), Policy Brief on Women's Entrepreneurship, doi:10.2767/50209. https://www.oecd.org/cfe/smes/Policy-Brief-on-Women-s-Entrepreneurship.pdf

OECD/EU (2015), "Policy Brief on Expanding Networks for Inclusive Entrepreneurship", http://dx.doi.org/10.1787/5jrtpbz29mjh-en

Piacentini, M. (2013), "Women Entrepreneurs in the OECD: Key Evidence and Policy Challenges", OECD Social, Employment and Migration Working Papers, No. 147, OECD Publishing, Paris, DOI: http://dx.doi.org/10.1787/5k43bvtkmb8v-en

Pieters, J. (2015), "Trade liberalization and gender inequality", IZA World of Labor, No. 2015:114. DOI: http://dx.doi.org/10.15185/izawol.114

ProChile (2019), Estudio de Brechas y Barreras de Género para la Exportación en Empresas Lideradas por Mujeres, https://www.prochile.gob.cl/wp-content/uploads/2019/05/informe encuesta genero.pdf.

ProChile and Subsecretaria de Relaciones Económicas Internacionales (2019), Tercera Radiografía a la Paticipación de las Mujeres en las Exportaciones Chilenas, https://www.prochile.gob.cl/wpcontent/uploads/2019/12/Tercera-Radiograf\%C3\%ADa-Mujeres-Exportadoras.pdf.

Rodrik, D., A. Subramanian and F. Trebbi (2004), Institutions Rule: The Primacy of Institutions Over Geography and Integration in Economic Development. Journal of Economic Growth 9, 131-165. https://doi.org/10.1023/B:JOEG.0000031425.72248.85

Rueda-Cantuche, J. Manuel, Z. Kutlina-Dimitrova and N. Sousa (2019), Female Participation in EU exporting activities: Jobs and wages, Chief Economist Note, issue 3, September.

Rueda-Cantuche, J.M. and N. Sousa (2017), Are EU exports gender-blind? Some key features of women participation in exporting activities in the EU, Chief Economist Note, issue 3, June.

Sandberg, S. (2013), Lean In: Women, Work and the Will to Lead, Knopf Publishers.

Sauré, P., and H. Zoabi (2014). "International Trade, the Gender Wage Gap and Female Labor Force Participation." Journal of Development Economics 111 (November): 17-33.

Sekkel, J. (2020), "Women-owned SMEs and Trade Barriers", Global Affairs Canada, 04-02-2020, 
https://www.international.gc.ca/trade-commerce/economist-economiste/analysisanalyse/women owned smes trade-pme commerce appartenant femmes.aspx?lang=eng

Shepherd, B. (2018), Global Value Chains and Women's Labor: Firm-Level Evidence, Working Paper DTC-2018-6, 14 November 2018.

Shepherd, B. and S. Stone (2017), Trade and Women. ADBI Working Paper 648. Tokyo: Asian Development Bank Institute. https://www.adb.org/publications/trade-and-women.

Shepherd B and S. Stone (2013), "Global Production Networks and Employment: A Developing Country Perspective," OECD Trade Policy Papers 154, OECD Publishing.

Solís M. and S.N. Katada (2009), Explaining FTA Proliferation: A Policy Diffusion Framework. In: Solís M., Stallings B., Katada S.N. (eds.) Competitive Regionalism. International Political Economy Series. Palgrave Macmillan, London.

Suominen, K. (2018), Women-led Firms on the Web: Challenges and Solutions. Geneva: International Centre for Trade and Sustainable Development (ICTSD).

Tamburrini, A., K. Gilhuly and B. Harris-Roxas (2011), "Enhancing benefits in health impact assessment through stakeholder consultation", Impact Assessment and Project Appraisal, 29:3, p. 195-204, DOI: 10.3152/146155111X12959673796281.

Thébaud, S. (2010), "Gender and Entrepreneurship as a Career Choice: Do Self-Assessments of Ability Matter?" Social Psychology Quarterly, Vol. 73(2), http://dx.doi.org/10.1177/0190272510377882

UNCTAD (2019), Making Trade Policies Gender-responsive: Data Requirements, Methodological Developments and Challenges, UNCTAD/DITC/2019/1, United Nations Publications, Geneva.

UNCTAD (2017), The new way of addressing gender equality issues in trade agreements: is it a true revolution?, Policy Brief no 53.

UNCTAD and UN Women (2020), Gender and Trade, Assessing the Impact of Trade Agreements on Gender Equality: Canada-EU Comprehensive Economic and Trade Agreement, https://unctad.org/en/PublicationsLibrary/UNWomen 2020d1 en.pdf

United Nations (2015), The World's Women 2015, http://unstats.un.org/unsd/gender/worldswomen.html

Uzzi, B. (1999), "Embeddedness in the Making of Financial Capital: How Social Relations and Networks Benefit Firms Seeking Financing", American Sociological Review, Vol. 64, pp. 481-505.

Wagner, J. (2007), "Exports and Productivity: A Survey of the Evidence from Firm-level Data", The World Economy, Vol. 30, No. 1, pp. 60-82.

Weeden, K., Y. Cha and M. Bucca (2016), Long Work Hours, Part-Time Work, and Trends in the Gender Gap in Pay, the Motherhood Wage Penalty, and the Fatherhood Wage Premium, The Russell Sage Foundation Journal of Social Sciences, vol. 2, no. 4 August.

World Bank (2019), Women, Business and the Law 2019: A Decade of Reform, Washington, DC, https://openknowledge.worldbank.org/bitstream/handle/10986/31327/WBL2019.pdf? sequence=4\&isAl lowed=y

World Bank (2012), World Development Report 2012: Gender Equality and Development, World Bank, Washington, DC.

World Bank and World Trade Organization (2020). Women and Trade: The Role of Trade in Promoting Gender Equality. World Bank, Washington, DC.

World Bank Group and World Trade Organization (2015), The Role of Trade in Ending Poverty. World Trade Organization: Geneva.

World Bank (2018), The Future of Business Survey: Financing and Women-owned, Small Businesses, the Role of Size, Age and Industry, March, https://dataforgood.fb.com/wpcontent/uploads/2019/03/Future-Of-Business Access-to-Capital March-2018.pdf

World Economic Forum (2019), Global Gender Gap Report 2020, http://www3.weforum.org/docs/WEF GGGR 2020.pdf 
World Trade Organisation (2019), World Trade Report 2019: The Future of Services Trade, https://www.wto.org/english/res e/booksp e/00 wtr19 e.pdf

World Trade Organisation (2017), World Trade Report 2017: Trade, Technology and Jobs, https://www.wto.org/english/res e/booksp e/world trade report17 e.pdf. 
Annex A. Women in export-supported employment

Table A.1. Share of women in employment and in export-supported employment

\begin{tabular}{|c|c|c|c|c|c|c|}
\hline & \multicolumn{3}{|c|}{ Share of women in total employment } & \multicolumn{3}{|c|}{ Share of women in export-supported employment } \\
\hline & 2008 & 2015 & $\begin{array}{c}\text { Change in } \\
\text { percentage point }\end{array}$ & 2008 & 2015 & $\begin{array}{c}\text { Change in } \\
\text { percentage point }\end{array}$ \\
\hline AUS & 45.2 & 46.3 & 1.1 & 41.7 & 42.2 & 0.6 \\
\hline AUT & 45.8 & 47.1 & 1.3 & 39.7 & 40.7 & 1.0 \\
\hline BEL & 44.6 & 46.5 & 1.9 & 37.2 & 39.6 & 2.4 \\
\hline CAN & 47.3 & 47.5 & 0.2 & 40.2 & 40.4 & 0.3 \\
\hline $\mathrm{CHE}$ & 45.1 & 46.2 & 1.2 & 39.3 & 39.6 & 0.3 \\
\hline $\mathrm{CHL}$ & .. & 40.8 & .. & .. & 31.7 & .. \\
\hline CZE & 42.8 & 43.7 & 1.0 & 40.3 & 40.7 & 0.4 \\
\hline DEU & 45.4 & 46.6 & 1.2 & 38.3 & 39.5 & 1.2 \\
\hline DNK & 46.8 & 46.9 & 0.1 & 39.3 & 38.1 & -1.2 \\
\hline ESP & 42.3 & 45.4 & 3.0 & 38.6 & 39.2 & 0.6 \\
\hline EST & 49.1 & 48.8 & -0.3 & 46.6 & 43.7 & -2.9 \\
\hline FIN & 48.1 & 48.7 & 0.7 & 37.9 & 36.8 & -1.1 \\
\hline FRA & 47.2 & 48.4 & 1.2 & 41.1 & 41.7 & 0.7 \\
\hline GBR & 46.2 & 46.8 & 0.6 & 40.0 & 40.9 & 0.9 \\
\hline GRC & 39.6 & 42.2 & 2.7 & 34.5 & 37.5 & 3.0 \\
\hline HUN & 45.6 & 45.8 & 0.2 & 42.7 & 41.2 & -1.5 \\
\hline IRL & 44.0 & 45.7 & 1.7 & 42.0 & 40.6 & -1.5 \\
\hline ISL & 45.5 & 47.7 & 2.2 & 38.7 & 42.0 & 3.2 \\
\hline ISR & .. & 47.1 & .. & .. & 43.3 &.. \\
\hline ITA & 40.1 & 41.8 & 1.6 & 34.6 & 35.2 & 0.6 \\
\hline JPN & .. & 44.9 & .. & .. & 38.8 & .. \\
\hline KOR & .. & 42.1 & .. & .. & 34.6 &.. \\
\hline LTU & 49.5 & 51.0 & 1.5 & 48.0 & 45.8 & -2.2 \\
\hline LUX & 42.8 & 45.1 & 2.3 & 41.6 & 44.2 & 2.5 \\
\hline LVA & 49.6 & 50.4 & 0.8 & 46.4 & 43.8 & -2.6 \\
\hline NLD & 46.0 & 45.9 & -0.1 & 40.7 & 39.8 & -0.9 \\
\hline NOR & 46.9 & 47.2 & 0.3 & 37.0 & 36.6 & -0.4 \\
\hline NZL & 46.9 & 47.2 & 0.3 & 42.3 & 42.5 & 0.2 \\
\hline POL & 44.8 & 44.9 & 0.1 & 40.3 & 40.0 & -0.3 \\
\hline PRT & 46.7 & 48.7 & 1.9 & 43.2 & 43.2 & -0.1 \\
\hline SVK & 44.0 & 44.3 & 0.4 & 40.7 & 39.7 & -1.0 \\
\hline SVN & 45.5 & 45.4 & 0.0 & 41.7 & 40.2 & -1.5 \\
\hline SWE & 47.3 & 47.7 & 0.4 & 38.2 & 39.0 & 0.8 \\
\hline TUR & .. & 30.2 & .. & .. & 28.8 &.. \\
\hline USA & 46.8 & 46.9 & 0.2 & 38.1 & 38.3 & 0.2 \\
\hline OECD & 45.0 & 45.2 & 0.2 & 39.1 & 38.6 & -0.5 \\
\hline
\end{tabular}

Source: Secretariat estimates based on OECD's Trade in Employment database, 2019: http://oe.cd/io-emp. 
Figure A 1. Employment by gender in domestic and foreign final demand, 2015

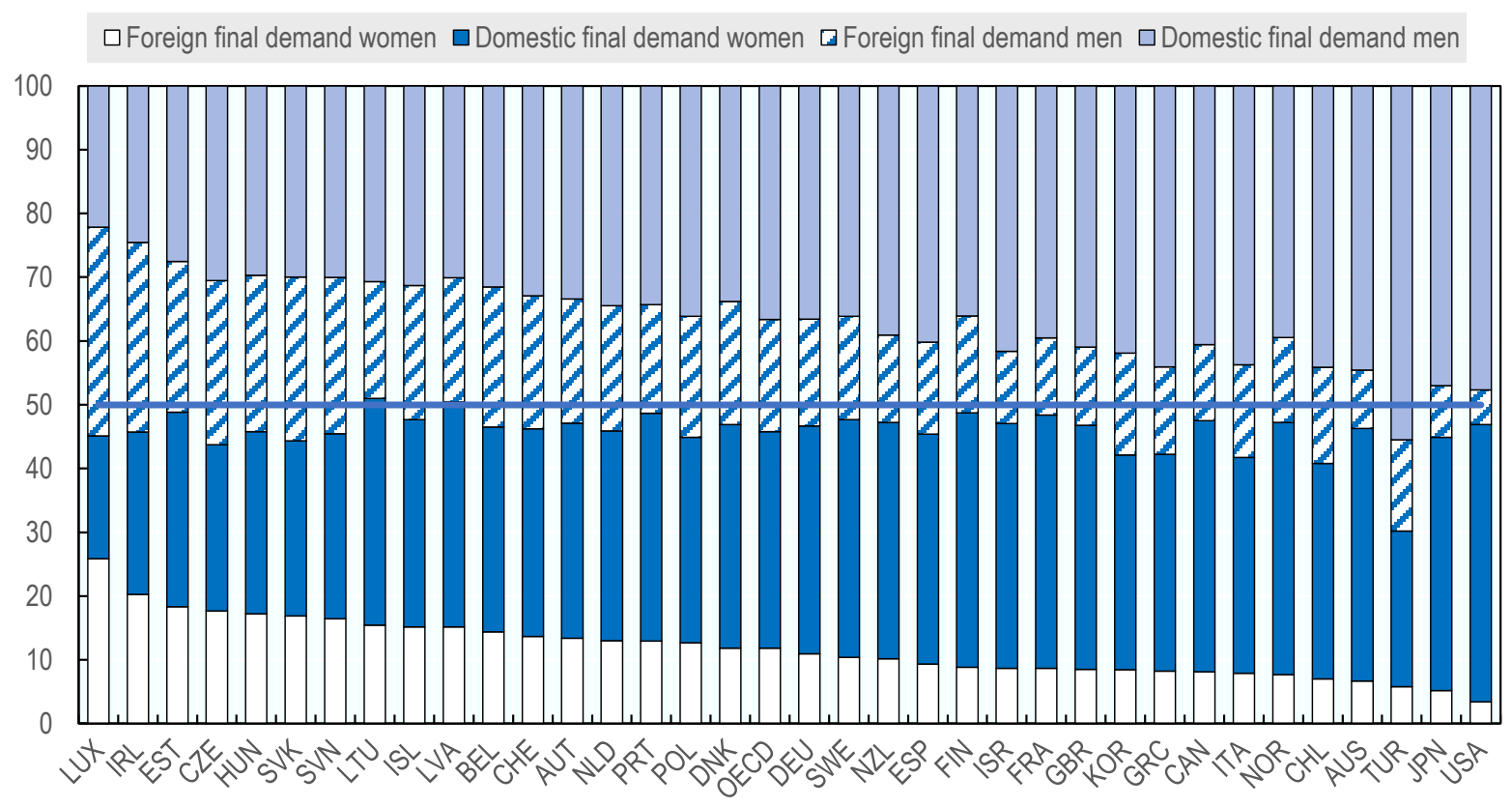

Note: Data ordered by the highest share of women meeting foreign final demand.

Source: Secretariat estimates based on OECD's Trade in Employment database, 2019: http://oe.cd/io-emp.

Table A.2. Share of women in employment and in export-supported employment by broad sectors

\begin{tabular}{l|c|c|c|c|c|c}
\hline & \multicolumn{3}{|c|}{ Share of women in total employment } & \multicolumn{2}{c}{$\begin{array}{c}\text { Share of women in export-supported } \\
\text { employment }\end{array}$} \\
\hline & 2008 & 2015 & $\begin{array}{c}\text { Change in } \\
\text { percentage point }\end{array}$ & 2008 & 2015 & $\begin{array}{c}\text { Change in } \\
\text { percentage point }\end{array}$ \\
\hline Agriculture, forestry and fishing & 29.1 & 35.7 & 6.6 & 30.0 & 33.0 & 3.0 \\
\hline Manufacturing & 29.2 & 28.0 & -1.2 & 28.6 & 26.9 & -1.7 \\
\hline Construction & 8.4 & 10.1 & 1.7 & 9.2 & 9.8 & 0.6 \\
\hline Business services & 44.0 & 43.1 & -0.9 & 43.5 & 42.3 & -1.2 \\
\hline $\begin{array}{l}\text { Community, social and personal } \\
\text { services }\end{array}$ & 65.2 & 64.8 & -0.4 & 67.9 & 66.9 & -1.0 \\
\hline TOTAL & 45.0 & 45.2 & 0.2 & 39.1 & 38.6 & -0.5 \\
\hline
\end{tabular}

Note: ISIC divisions 05-09 (Mining and quarrying) 35 (Electricity, gas, Steam and air conditioning supply and 36-29 (Water supply; sewerage, waste management and remediation activities) are not present in table.

Source: Secretariat estimates based on OECD's Trade in Employment database, 2019: http://oe.cd/io-emp. 


\section{Annex B. Comparative tariff rates on feminine sanitary products and diapers}

\section{Table B 1. Tariffs on feminine hygiene products and diapers}

Effectively applied rates, 2012 and 2018

\begin{tabular}{l|c|c|c|c|c|c}
\hline & & 2018 & & 2012 & \\
\hline & HS 961900 & HS 96 & Total & HS 961900 & HS 96 & Total \\
\hline United States & 6.06 & 2.58 & 2.61 & 6.41 & 2.92 & 2.90 \\
\hline Mexico & 5.61 & 5.45 & 3.24 & 13.00 & 12.08 & 6.77 \\
\hline New Zealand & 4.85 & 2.38 & 2.09 & 6.65 & 3.73 & 2.93 \\
\hline Canada & 4.11 & 2.40 & 2.00 & 8.30 & 4.02 & 3.32 \\
\hline Australia & 2.88 & 2.20 & 2.20 & 4.51 & 2.66 & 2.75 \\
\hline OECD & 2.51 & 1.84 & 2.18 & 4.29 & 2.6 & 2.68 \\
\hline Israel & 1.96 & 3.41 & 1.63 & 2.40 & 3.47 & 1.67 \\
\hline Korea & 1.86 & 2.11 & 5.17 & 8.16 & 7.79 & 9.33 \\
\hline European Union & 1.66 & 1.48 & 1.87 & 0.84 & 0.75 & 1.63 \\
\hline Turkey & 1.18 & 1.07 & 2.64 & 1.35 & 0.67 & 2.40 \\
\hline Chile & 1.00 & 1.00 & 1.05 & 2.69 & 2.95 & 2.71 \\
\hline Iceland & 0.00 & 0.00 & 0.25 & 2.70 & 3.04 & 1.77 \\
\hline Japan & 0.00 & 1.84 & 2.35 & 2.11 & 1.87 & 2.44 \\
\hline Norway & 0.00 & 0.00 & 0.74 & 0.00 & 0.00 & 0.50 \\
\hline
\end{tabular}

Note: Tariff rates refer to simple averages of effectively applied rates. If preferential rates are applied with respect to certain trading partners, those rates are used; otherwise MFN rates are used. HS 96190 refers to Sanitary towels (pads) and tampons, napkins and napkin liners for babies and similar articles, of any material; HS96 refers to the overall category of Miscellaneous manufactured articles; "Total" refers to all products.

The statistical data for Israel are supplied by and under the responsibility of the relevant Israeli authorities. The use of such data by the OECD is without prejudice to the status of the Golan Heights, East Jerusalem and Israeli settlements in the West Bank under the terms of international law.

Source: UN Trains. 


\section{Annex C. Characteristics of women-owned firms and the barriers women face to entrepreneurship}

\section{Characteristics of women-owned and women-led firms}

\section{Women are less likely than men to own and manage a business and their businesses are smaller and younger}

Women are less likely than men to be self-employed. In the OECD, $10 \%$ of women and $17 \%$ of men declared that they were self-employed in 2015 (OECD/EU, 2017) and this rate has been constant for over a decade. Moreover, across OECD countries, self-employed women are less likely than self-employed men to have hired additional employees to work for their businesses: in 2016, 32\% of self-employed men and $22 \%$ of self-employed women had employees (OECD, the Missing Entrepreneurs, 2017). Similarly, among businesses with a Facebook presence, more firms are led by men. Thirty-seven per cent of online businesses with a Facebook presence were owned or managed by women, compared with $44 \%$ by men (Facebook-OECD-World Bank Future of Business survey, June 2019). ${ }^{96}$

Self-employment is widely perceived as a more risky activity than salaried employment, and gender differences in business ownership rates may in part be explained by women's greater aversion to risk. In Europe, $40 \%$ of women and $28 \%$ of men report being risk averse (European Commission, 2010). Selfemployed women are less risk averse than the overall population of women, and the self-employed who own or manage an enterprise even less so (Piacentini, 2013).

Women-owned businesses are generally smaller than those owned by men. In 2016, 31.8\% of self-employed men and $21.8 \%$ of self-employed women in OECD countries had employees, and this has changed only slightly over the last decade (OECD/EU, 2017). Similarly, among firms with a Facebook presence, women-owned firms have fewer, if any, employees (Figure C.1). As firm size increases, the presence of women in management and ownership diminishes. One-quarter of medium-sized enterprises (50-249 employees) are women-led, and only one-fifth of large firms (over 250 employees) are women-led.

Moreover, women-owned businesses generate less revenue. In the United States, women-owned businesses averaged earnings of USD 14900 compared to USD 47900 for all privately held businesses and USD 1.4 million for all firms, including publicly traded companies in 2019 (American Express, 2019). Similarly, in other OECD countries, turnover of women-owned businesses is less. The average turnover of individual enterprises (i.e. sole-proprietorships) owned by women was only $18 \%$ of those owned by men in the Netherlands, 26\% in Italy, 38\% in Mexico, and 44\% in Finland in 2009 (Piacentini, 2013).

\footnotetext{
${ }^{96}$ Nineteen per cent of businesses on Facebook were equally owned or managed by women and men.
} 
Figure C.14. Firm size by gender of owner/manager

Share of surveyed firms with a Facebook presence in OECD Member countries, per cent

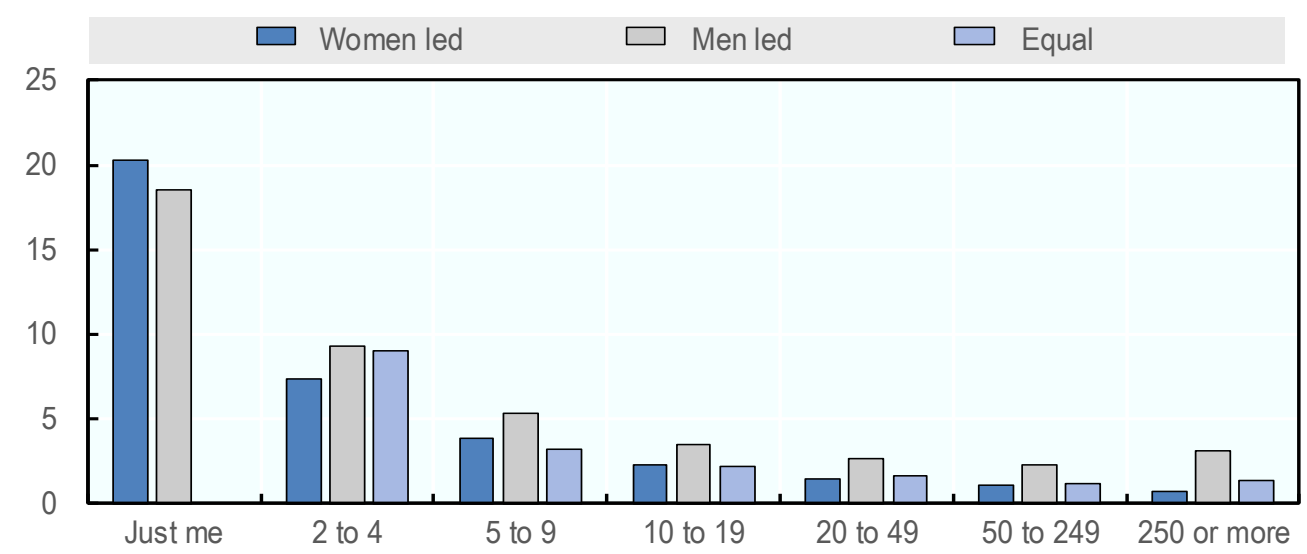

Source: Facebook-OECD-World Bank Future of Business survey, June 2019.

Women-led firms tend to be younger than the average. In the United States, the average age of womenled firms is 43 months, compared with the average of 52 months for those not led by women in 2018 (Biz2Credit, 2019; Goldstein et al., 2019) Among firms with a Facebook presence, firms owned and led by men are overwhelmingly represented among firms that have existed for over ten years (Facebook-OECDWorld Bank Future of Business survey, June 2019).

Women entrepreneurs tend also to have less experience than men in owning and managing a business. On average across 15 European countries, only $11 \%$ of women who started a new enterprise in 2002 had run another business before the start-up, compared with 18\% of men (Piacentini, 2013). Women entrepreneurs also tend to be younger than their men entrepreneurs.

\section{Women-owned businesses are concentrated in a few sectors}

Women-owned businesses tend to be concentrated in services sectors. Eighty per cent of women-owned firms are in services compared with $67 \%$ of those owned by men with a Facebook presence (Figure C.2). Ninety per cent of Canadian women-owned businesses operate in the service sector compared to $70 \%$ of men-owned businesses. (Bélanger Baur, 2019). Across the OECD, women were less likely than men to be self-employed across all industries except for "other services", which includes personal and household services (OECD/EU, 2017). In the United States, half of all women-owned businesses are concentrated in three industries: other services, including hair and nail salons and pet care businesses; healthcare and social assistance, including child day care and home healthcare services; and professional, scientific and technical services, including lawyers, bookkeepers, architects, public relations firms, and consultants (American Express, 2019). 


\section{Figure C.15. Women led firms are concentrated in services sectors}

Share of firms with a Facebook presence in OECD countries in 2019
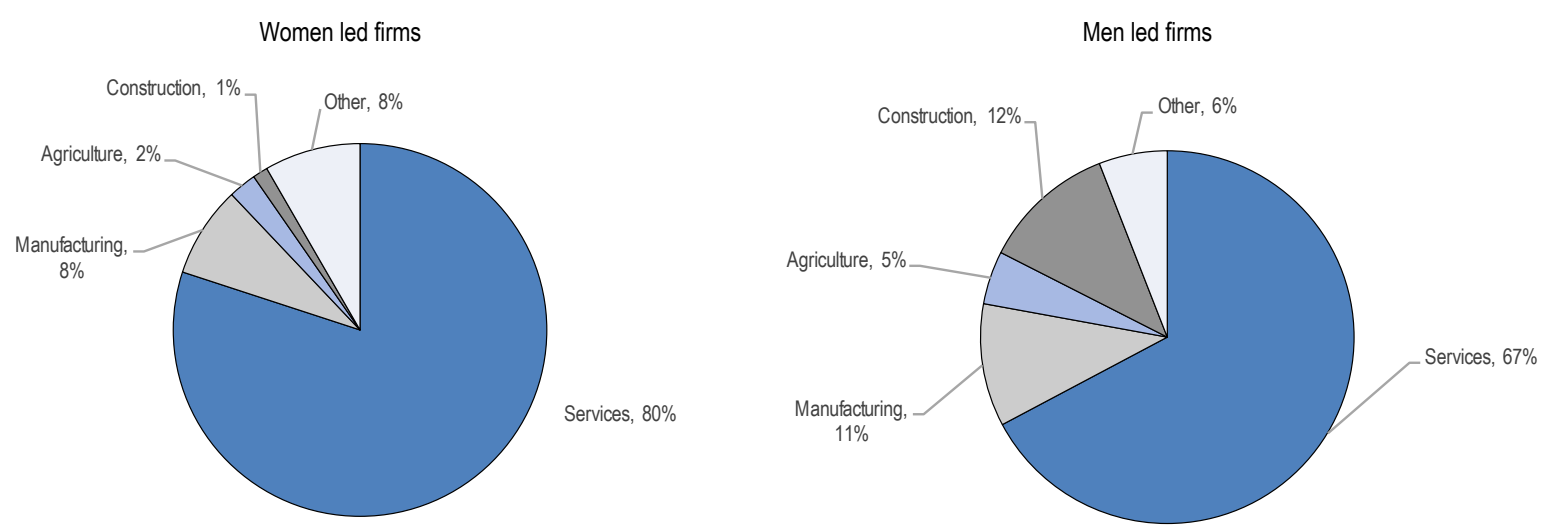

Source: Facebook-OECD-World Bank Future of Business survey of online firms, June 2019.

\section{Women-owned firms are associated with lower productivity}

The characteristics of women-owned firms outlined above are often associated with lower productivity. Enterprises owned by women are $5 \%$ to $30 \%$ less productive, defined as having a lower value-added per employee, than enterprises owned by men (Piacentini, 2013). The lower capital intensity of women-owned enterprises is the most decisive factor in their lower productivity and explains $38 \%$ of the shortfall (Piacentini, 2013). The industries in which they operate also account for a substantial share of the productivity gap (23\%). A significant fraction of the productivity difference between men and women-owned enterprises, however, is not explained by the observable characteristics of their businesses.

Although women-owned businesses tend to be smaller and less productive, they appear to be as resilient to changes in economic conditions as men-owned businesses in many countries. This resilience may be partly explained by the nature of women-operated businesses, which tend to focus on health services, educational services and other personal service sectors that are less susceptible to economic downturns.

\section{Women start businesses for different reasons than men do}

There are considerable differences in the motivation of men and women to become entrepreneurs. Far more women than men enter entrepreneurship to pursue a passion, to have a better work/life balance and to be more independent (Figure C.3). More men lead businesses because they have taken over a family firm or to make money (Facebook-OECD-World Bank Future of Business survey, June 2019). Moreover, women may chose entrepreneurship to a greater extent due to an inability to enter or advance in the workforce or to work part-time (Annex C, Box C.1). 


\section{Figure C.16. Motivations to pursue entrepreneurship}

Differences between men and women, per cent responding affirmatively

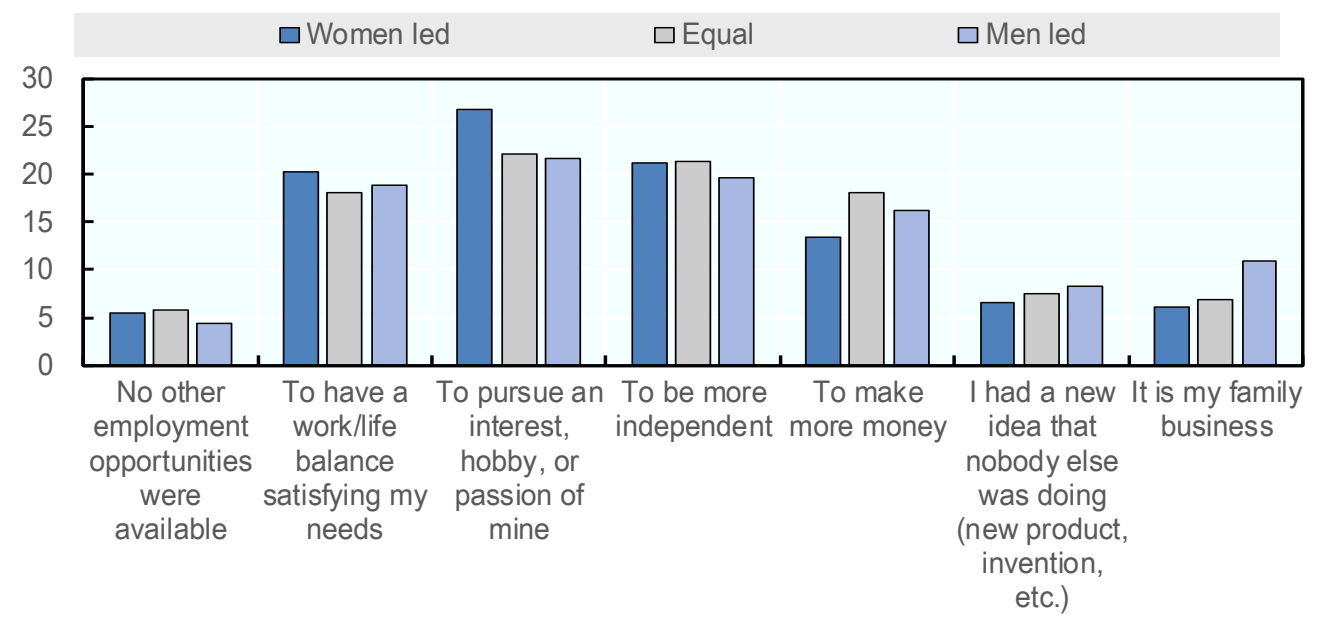

Note: Entrepreneurs whose firms have a Facebook presence.

Source: Facebook-OECD-World Bank Future of Business survey of businesses with a Facebook presence, June 2019.

\section{Box C.1. Types of entrepreneurship}

Entrepreneurs start their businesses for a complex set of reasons, and many of them depend on the other economic opportunities available to them. Necessity entrepreneurs are unemployed or cannot find quality employment. Their only viable employment option is to start a business. In times of high economic growth, necessity entrepreneurship declines. Flexibility entrepreneurs start their own businesses because workforce policies do not accommodate their caregiving responsibilities or they desire more control over when and where they work. In particular, some women move into entrepreneurship because they find they have hit a "glass ceiling" and cannot advance in their careers. While some necessity and flexibility entrepreneurs grow successful businesses, for the most part they return to the labour force when they can. Opportunity entrepreneurs see possibilities in the market that they want to exploit. They are more likely to enter the market in good economic times than in bad. These businesses tend to have a higher rate of survival and better growth prospects.

Part-time entrepreneurship is often called sidepreneurship. The rate of growth in the number of sidepreneurs is far greater than for all ventures. Between 2014 and 2019, growth in sidepreneurship was higher for women (39\%) than for all adult entrepreneurs (32\%).

Source: American Express (2019).

Tax policies can also impact women's participation in the labour market and in entrepreneurship. Tax policies that favour a dual earner model are more likely to foster labour market participation and business activity by women (OECD-European Union, 2016). 


\section{Barriers to women's entrepreneurship and to growing their businesses}

The smaller size of women-owned and led businesses and their lower productivity can be explained in part by a number of barriers to their entry into entrepreneurship, and their ability to grow their businesses. First and foremost is their lack of access to finance: women entrepreneurs lag behind men entrepreneurs in the credit they request and even more so in the financing that they obtain. Women also have fewer and more shallow networks and less time to devote to their businesses. They report that they do not have the skills required to pursue entrepreneurship, such as business and financial planning, to a greater extent than men, although they are generally better educated.

\section{Access to finance}

Women entrepreneurs have greater difficulty accessing finance than men across all countries, and the gap is often substantial. In seven European Union countries, men are more than 1.5 times as likely as women to report that they could access the finance to start a business (OECD/EU, 2016). A survey of women and men entrepreneurs in eight OECD and emerging markets found that women entrepreneurs received $57 \%$ of the funding they requested, compared with $61 \%$ for men (HSBC, 2019). In the United States, Biz2credit, a leading online credit marketplace for small firms, reports that the average approved amount for womenowned businesses was USD 43534 compared to USD 69268 for men-owned businesses, a difference of $59 \%$.

Since access to credit is a barrier to women's entrepreneurship, supporting women's entrepreneurship may begin by prohibiting outright discrimination. In six OECD countries - Chile, Japan, Turkey, Israel, Switzerland and Korea - creditors are not prohibited by law from discriminating on the basis of gender (World Bank, 2019). Prohibiting discrimination would be a good first step; even in countries with strict laws in place against gender discrimination in awarding credit, unconscious bias exists.

When applying for financing, some women entrepreneurs experience gender bias, most often in the form of more personal questions, additional documentation or a concentrated focus on the downsides of their business plan. Women are more likely to be questioned about their family circumstances $(33 \%$ compared with $21 \%$ for men), reflecting the perception among investors that women-led businesses may take second place to family priorities. Investors were also more inclined to question women more on the topic of loss prevention (31\% versus $22 \%$ ), suggesting that they have less confidence in their abilities compared to men (HSBC, 2019). In the United States, the average credit score for women-owned businesses (588) was 25 points lower than men-owned businesses (613) in 2018 (Biz2credit, 2019). In Canada, women entrepreneurs had to provide lenders with more documentation - such as personal financial statements, appraisals of assets and cash flow projections - than men entrepreneurs (Jung, 2010).

Venture capital (VC) and related risk-finance instruments play a critical role in fostering the scaling-up of the very small proportion of firms that prove to be successful. ${ }^{97}$ Moreover, venture capitalists often provide mentoring in addition to funding, helping to recruit, formulate new strategies, and use their networks to obtain resources for the company. Furthermore, the backing of venture capital firms provides a signal of the quality of a new venture to other potential investors or partners (Breschi et al., 2018).

\footnotetext{
${ }^{97}$ While VC funds invest in only $0.2 \%$ of new businesses in the United States, $43 \%$ of US public companies founded between 1979 and 2013 were VC-backed, and they accounted for $82 \%$ of the total research and development expenditure of public companies (Breschi et al., 2018). However, there are substantial differences across OECD countries in the relative size of the venture capital market, with economies like Israel and the United States having a VC-to-GDP ratio ten times as large as the average European country (OECD, 2015).
} 
The gender gap in VC funding is particularly stark. ${ }^{98}$ Only $2 \%$ of VC funding goes to women-only start-ups in France vs. $89 \%$ for start-ups led only by men ( $9 \%$ for mixed teams). Women-only start-ups account for $1 \%$ of total VC funding in Germany and 5\% in the United Kingdom (Boston Consulting Group, 2019). In Germany, women-led start-ups raise 3.1 times less funds than men-led start-ups; in France they raise 2.5 times less and in the United Kingdom, 1.3 times less.

Fewer women investors may be correlated with less VC funding to women entrepreneurs because many venture capitalists and angel investors make their investment decisions in partnership and on the basis of information provided by their networks (Hochberg et al., 2007). In the United States, $7 \%$ of VC funds went to women entrepreneurs, a share that was mirrored by $7 \%$ women VC decision-makers in $2015 .{ }^{99}$ In 2018 , both the share of $\mathrm{VC}$ funding provided to women entrepreneurs and the share of women decision-makers in VC funds dropped to $2.2 \% .{ }^{100} \mathrm{It}$ is unclear why this drop in funding women entrepreneurs through VCs has occurred. ${ }^{101}$

Consequently, women entrepreneurs typically start their businesses with less money and are more reliant on self-financing. The gender wage gap and, in some cases, less access to household resources, means that women often have fewer resources than men to invest. Moreover, in some countries such as under Chile's default matrimonial regime, women do not have equal ownership rights to property, nor do they have equal administrative authority over assets during marriage (World Bank, 2019). ${ }^{102}$ Such discriminatory policies impact women's access to capital that they might invest in a business. In France, $40 \%$ of the women founders of new enterprises in 2006 invested less than EUR 4000 in their start-up. In the United States too, a high percentage of women-owned enterprises were founded with initial capital of USD 5000 or less (Piacentini, 2013). Adequate capitalisation in the start-up phase means higher chances of achieving greater productivity and of firm survival during the first years.

\section{Access to information and networks}

Strong networks can be a crucial conduit for enabling access to capital. In particular, networks enable an entrepreneur to consolidate her credibility and trustworthiness with existing investors and to build relationships with more diverse, and more substantial, providers of capital (Ernst and Young, 2013). Access to networks is fundamental for smaller businesses to manage common problems, reduce information asymmetry, and build social capital to engage in more distant markets (Bamber and Staritz, 2016). However, women's entrepreneurship networks are more likely to include family, friends and educators rather than business services providers, other entrepreneurs (OECD/EU, 2015) or individuals who control critical resources (Brush et al., 2014). There is also evidence that women are less likely to be able to draw on relevant social capital from previous work experiences. In contrast, men are more engaged

98 The gap in funding even larger when considering additional factors such as race. The majority of start-ups founded by black women receive no VC funding. Black women have raised only $0.06 \%$ of all tech venture funding since 2009 . Only five black women are venture capital partners compared with 1630 white men (Source: The State of Black Women Founders, ProjectDiane2018 by digitalundivided, http://www.projectdiane.com/).

99 VC partners generally have a specific profile: $50 \%$ of VC partners have MBAs and $25 \%$ of VC partners have MBAs from Harvard University. Only five black women are venture capital partners compared with 1630 white men. According to information provided by the Women's Venture Capital Fund, VC partners with daughters invest more in women entrepreneurs.

100 Women tech entrepreneurs' interventions in the F pour Femme conference organised at the Station $\mathrm{F}$ in Paris on Oct. 1, 2019.

101 One hypothesis suggested by a woman investor at the $F$ pour Femme conference organised at the Station $\mathrm{F}$ in Paris on Oct. 1, 2019 is that it is an unintended consequence of the \#MeToo movement since VC investors often work very closely with entrepreneurs in a one-on-one business relationship.

102 Chile is the only OECD country where women do not have equal ownership rights to property under the default matrimonial regime of shared ownership (World Bank, 2019). Married couples can opt for one of the other two available matrimonial regimes, which provide for separate ownership of each spouse's assets. 
in networks of contacts with greater social and economic power, which can be advantageous in assisting in the gathering of information, resources and referrals (Uzzi, 1999).

Moreover, even when women join formal networks, they rate the benefits they obtain from them lower than do men. Only $32 \%$ of women leading businesses in the European Union found them to be relatively important compared with $42 \%$ of men leading firms (ITC, 2019). Some women entrepreneurs refer to chambers of commerce and formal business associations as 'old boys' clubs', and report that informal networks are often dominated by men (ITC, 2019).

\section{Women have less time}

Women engage in professional networking less, and have less time to put into their businesses in part because they engage in more unpaid work. Women spend much more time than men in unpaid childcare, elder care and housework. In Italy, for example, women spend 4.9 hours each day on housework while men spend 1.4; in Sweden, women spend 3.2 hours per day to men's 2.3. In both Italy and Sweden, women spend .6 hours on childcare while men spend half that in Sweden, and one-third in Italy (Berniell and Sánchez-Páramo, 2011). ${ }^{103}$ In the United States, working women spent half an hour less at work and half an hour more on household chores than their male partners. Working mothers in the United States spend just over two hours caring for children while working fathers spend less than an hour and a half. ${ }^{104}$

More hours spent in unpaid work gives women less time to spend at work, managing their businesses and engaging their networks. On average, self-employed women work more hours per week than women who work as employees, and the self-employed with employees tend to work more than those without employees. In the European Union, self-employed women with employees worked 47.3 hours per week in 2016 relative to 43.9 hours for those without employees. However, men worked more hours than women across all categories: employees, self-employed with employees and self-employed without employees (OECD/EU, 2017).

\section{Women report having insufficient entrepreneurial skills despite being better educated than men entrepreneurs}

Women who run a business have higher levels of educational attainments than men. On average across OECD countries, $33 \%$ of self-employed women and $27 \%$ of self-employed men have a tertiary education degree (Piacentini, 2013). However, women still tend to have less experience in self-employment and continue to have fewer opportunities than men in management positions, which acts as a barrier to gaining management experience and skills that are useful for entrepreneurship (OECD, 2019c). Moreover, women are less likely than men to report that they have access to training on starting and growing a business.

A lack of entrepreneurship skills can be a significant barrier to successful business start-up. This skillset refers to business management skills (e.g., business and financial planning), personal skills and traits (e.g., sense of initiative, risk management) and technical skills (e.g., problem solving). Across OECD countries, $37 \%$ of women and $51 \%$ of men indicated that they had sufficient skills, knowledge and experience to start a business over the 2013-17 period (OECD, 2019c). However, in countries with a higher share of women entrepreneurs such as the United States, Poland and Chile, approximately half of women self-reported that they have the knowledge and skills necessary for entrepreneurship.

\footnotetext{
${ }^{103}$ Figures are averaged over all participants, i.e. including families without children.

104 The American Time Use Survey, US Labor Department, referenced in the Wall Street Journal, "Women Working Longer Hours, Sleeping Less, as they Juggle Commitments", June 19, 2019.
} 


\section{Annex D. Linking data sources for gender-differentiated trade analysis: The case of Finland}

In order to better ascertain the impact of trade on women, micro-data on firms and on individuals would need to be combined with information on trade in goods and services. Ideally, firm-level data could be linked with employee data over time in order to give a comprehensive picture of individuals' changes in employment and characteristics. It has been possible to do this in Finland using unique identification numbers for businesses and individuals (Box D.1). These micro-data can also be linked to time-use surveys to capture changes in household composition and unpaid work within households.

Having a complete picture of firm and individual characteristics as well as their household information is far from the norm. However, individuals make decisions based both on their conditions in the labour market - employment status, wage level and change in wages, etc. - and the situation of their household and how resources are allocated within it. This point has been illustrated poignantly during the COVID-19 pandemic where the situation of single-parent households, the majority of which are headed by women, has been impacted both by severe changes in the labour market - job losses, furlough, involuntary part-time work or, conversely continued work for essential services - and changes in unpaid work in the household with increased childcare and other domestic responsibilities.

Box D.1. Linking micro-data to undertake gender-differentiated analysis of trade: The case of Finland

Statistics Finland has undertaken, with the OECD, a vast exercise to link micro-data sets, national accounts data, international trade statistics and Finnish Supply and Use Tables (SUTs). The data that has been linked across a number of sources.

- Several firm-level data sources, for example the business register, structural business statistics, international trade in goods and services data, and inward and outward foreign affiliate statistics are linked. The micro-data covers nearly all businesses in the Finnish private sector, and data are linked using unique Business ID numbers. All limited liability firms in Finland are legally bound to declare their financial statements, enabling Statistics Finland to combine information such as turnover, value added and R\&D purchases with trade flows, industry affiliation, ownership, size-class, and year of firm establishment.

- Linked employer-employee data covers the universe of the working age population in the private sector with detailed information on individual characteristics, such as education, age, annual wages, and gender. Labour inputs by educational attainment are used as a proxy for skills. Qualifications such as Science, Technology, Engineering, and Mathematics (STEM) and Deep Digital Competency (DDC), age, gender are also available income distribution. Some of the cross measures for labour input, including gender by skills, gender by age, qualification by age, and skills by age, all broken down by sector of activity.

- International trade data describe exports and imports of goods and services. International trade in services data is collected from about 3000 enterprises annually. Firms declare service imports and exports by partner country and service type; data cover GATS modes 1, 2 and 4. Firms are categorised with respect to the way they engage in GVCs, and includes exporters, importers, two-way traders and occasional and non-traders. The value of imports and exports is calculated from data maintained by the Finnish Tax Administration. 
- Supply-use tables are broken down by 80 industries and products and are then harmonized and consistent with the underlying national accounts at the time of their release.

The Finnish linked micro-data has been used to assess gender segregation in employment, wage differentials within firms and among firms with different characteristics (e.g., traders/non-traders, lower/higher-wage industries, firms most impacted by import competition). It allows evaluation of gender wage and employment gaps between firms that engage in GVCs and those that do not, as well as according to ownership. The study compares women's participation in sectors with overall wages in those sectors. Calculation of gender wage gaps can be corrected for women's and men's level of skills. They can also be corrected for differences in STEM skills and qualifications for deep digital content jobs among trading firms. Gender gaps can be viewed in a subset of firms such as high productivity or high growth firms. Wage gaps can be examined for a subset of workers, for example very high (or very low) earners.

Source: OECD and Statistics Finland (2020), Globalisation in Finland: granular insights into the impact on businesses and employment, http://www.stat.fi/tup/julkaisut/tiedostot/julkaisuluettelo/ykau_202000_2020_23449_net.pdf 


\section{Annex E. Domestic policy areas that most impact women's ability to benefit from trade}

Many of the barriers that women workers, entrepreneurs and consumers face to engaging in trade and increased economic empowerment go well beyond trade policies. Trade policy can only be part of a comprehensive set of policies to increase women's economic empowerment and open the way for increasing national incomes through greater use of women's skills through the labour market. The main complementary domestic policy areas are:

- Those that impact work/life balance. Maternity, paternity and parental care policies, affordable childcare and domestic services can give women and men greater freedom to pursue employment or entrepreneurship along with family responsibilities. Moreover, the self-employed generally have less access to benefits in case of caring for a sick child or maternity leave than employees. While women will probably be strongly negatively affected by the economic impacts of COVID-19, which may reverberate for a long time, they may also benefit from a related shift in the cultural norms of women's and men's engagement in unpaid work (see Box 6.2).

- Women's access to finance. This could include regulating against discrimination in access to credit, including more algorithm-aided processes if they remove some of the room for unconscious bias; ${ }^{105}$ ensuring that women have equal ownership rights to property; and that they have equal administrative authority over assets during marriage.

- Ensuring that women enter and remain in the high-growth IT and engineering sectors. Relevant policies to support girls in STEM include gender-differentiated coding classes, increased sensitivity in counselling and exposing primary and junior-high school girls and boys to potential women role models in the sciences and technology and efforts to encourage change in technology firms where the culture is dominated by men.

- Tax systems that do not penalise double-earner households support women employees and women entrepreneurs.

- Combatting unconscious bias in formal networks such as chambers of commerce and industry associations, as well as incubators that are supportive of women entrepreneurs.

- Legislation to combat harassment is critical for women's economic empowerment, and filling the gap in implementation of harassment legislation outside the employment relationship to protect women entrepreneurs.

- Streamlining procedures to start and close a business. Making it easy to move in and out of selfowned businesses and ensuring that start-up and wind-down costs are not dissuasive are key to nurturing entrepreneurship, especially for those women that do so for flexibility or necessity reasons (Box C.1 in Annex C).

- Support for vulnerable populations. Low-revenue firms, which encompass the majority of womenowned businesses, are symptomatic of a larger problem: some women are struggling to make ends meet and have a part-time company to supplement their income (American Express, 2019). When supportive policies are designed, whether to provide micro- and small-businesses owners with financial support or to provide training for entrepreneurs to export, such vulnerable groups who often have little access to resources may need to be specifically targeted. This aspect has become particularly important in the context of the COVID-19 pandemic (Box 6.2).

\footnotetext{
105 Algorithm based lending can remove some discretionary lending practices that discriminate against women; however, if algorithms are based on previous lending practices, including by gender, discriminatory practices could be perpetuated.
} 


\section{Annex F. A checklist for assessing and improving the gender responsiveness of trade policies}

Understanding the impacts of trade on women and the factors that influence them is critical for policy makers that seek to improve the gender responsiveness of their trade policies. In order to ensure that trade policies do not negatively affect women or hinder efforts to bridge the gender gap, that benefits and opportunities of trade can be equally shared between men and women, and that other domestic policies are harnessed to advance goals of inclusiveness, policy makers may want to subject their existing and proposed policies to a number of questions. The following section suggests a non-exhaustive list of those considerations.

\section{Data requirements}

- Are there appropriate gender-disaggregated data, on employment of women and men engaged in export-supported jobs both directly and indirectly by sector of activity? This is an important step before policy action can take place to improve women's involvement in trade. The OECD Trade in Employment dataset disaggregated by gender, combined with the Trade in Value Added (TiVA) data provides such data.

- Are there appropriate gender-differentiated data on business characteristics of firms, including trade, in order to ascertain what types of firms trade? Such data would support public policy for enabling women entrepreneurs to expand their businesses internationally. Much of the new evidence on women-led businesses in trade outlined in this paper comes from a survey of firms with a Facebook presence, which presents the drawback of only including only a subset of firms, however large. In order to cover a wider set of firms, gender-differentiated data would need to be combined at the firm level, preferably in a harmonized way in order to compare across OECD Member countries.

- Are there comprehensive data on credit approvals, credit guarantees, VC funding, angel investing and trade finance by gender? Such data would allow a more granular examination of access to credit which constitutes a major barrier to women entrepreneurs growing their businesses, including internationally. Publishing and analysing this information can also help to raise awareness since access to finance is one of the main barriers to women entrepreneurs.

- Is there analysis of public procurement contracts awarded by gender? Such data would help monitor commitments or stated preferences.

- Are there appropriate data on unpaid work? Such data would be helpful to better understanding differences both in labour force participation and in time spent in entrepreneurship.

- Are there appropriate data on household consumption that differentiate on the basis of household composition, and the gender of head of household? Such data would provide increased understanding of differences in expenditure patterns which would in turn allow a more granular analysis of impacts of trade policies on women at different income levels.

\section{Impact analysis and monitoring}

- Are gender impact assessments undertaken when developing domestic economic regulations and policies or negotiating trade agreements? The incorporation of a gender-specific impact analyses in the context of regulatory reforms would help recognise potential positive and negative effects of the proposed policies and ensure that gender responsive measures are promoted throughout the regulation. Trade will not necessarily reduce gender gaps in labour participation and 
entrepreneurship but its effects on women and men should be measured; domestic policies may be necessary to ensure women can benefit from trade agreements. Gender impact assessments in the context of trade negotiations would inform negotiating strategies for market access, estimating impacts on women and men in terms of job losses and gains and identifying the necessary domestic policies to accompany the agreement's provisions. The collection of genderdisaggregated data would help to gain insights of potential impacts in various policy areas and greatly support the quality and comprehensiveness of such impact assessments.

- Are gender-related provisions in trade policies or agreements monitored after they have been enacted and some experience on their implementation has been obtained? The aim of such monitoring would be to ensure that gender-related provisions achieve their intended objectives and to adjust them to evolving circumstances. Ex post impact analysis of gender-related provisions in trade agreements can also monitor and confirm information regarding gender specific impacts.

- Are gender-differentiated data on employment, wage gaps and financing by VC firms made publicly available to help raise awareness? The publication of such data, in addition to enabling finer analysis and more relevant policy decisions, can go a long way to changing mind-sets. Requesting firms to publish their employment figures by gender and their gender wage gap at all levels, which is becoming more widespread within OECD, can support such change. Mandatory gender pay gap reporting for businesses is a necessary first step to obtain more information on and further analyse how trade affects the gender wage gap. Publishing gender differentiated financing by VC firms, and calling out firms that do not share their data, can help to apply peer pressure. Publishing and comparing VC firms' harassment policies can also underscore differences and point to firms that take harassment more or less seriously.

- Are gender considerations included in countries' WTO Trade Policy Reviews (TPR)? Moving forward these considerations could be included as standard content in the TPRs, instead of voluntarily as has been the case so far. Since 2018, 18 WTO Members (53\%) have voluntarily included information on their gender responsive trade policies as part of their TPRs (out of 34 reviews conducted between January 2018 to September 2020). Five of these Members have dedicated specific chapters or sections on this issue and have mentioned the Buenos Aires Declaration. However, these have generally been more of a vehicle for countries to showcase what they have done rather than an assessment of their progress in this area. Including an assessment of some of the aspects of trade and gender outlined in this report in all TPRs would raise awareness of trade-related issues the women face in WTO member countries.

\section{Women's institutional empowerment}

- Are women involved in the conception of trade policies and trade agreements? Their involvement is key to reinforcing the role such policies and agreements can play in promoting gender considerations. In order to take into consideration women's needs and viewpoints, it is necessary to ensure women are represented in decision-making. This includes when trade negotiations are undertaken. Teams of trade negotiators that are all or mostly made up of men are less mindful of the impacts on women of the agreements they are negotiating.

- Are consultations before, during and after trade agreement negotiations undertaken and do they incorporate gender perspectives? Such consultations increasingly take place within different Ministries and government agencies and with the private sector, civil society and wider stakeholder groups in OECD countries and are an invaluable tool for incorporating gender perspectives and highlighting unintended negative effects and identifying promising paths for gender-responsive outcomes. 


\section{Market access}

- Are trade policies designed and trade agreements negotiated in a way that considers their differential impact on men and women workers and entrepreneurs? Are there efforts to promote market access in sectors in which women work and own businesses? Women and men work and lead businesses in different sectors, and they are affected by market access in the sectors in which they work, whether they concern directly exporting sectors or sectors providing them inputs. Trade policies and trade agreements that offer greater market access in sectors in which women work and own businesses will allow them to engage more in international markets and reap the gains from trade. Conversely, policy-induced changes in sectors that stand to lose from import competition could impact the gender wage gap and women's participation in the labour force, if such policies were to affect sectors in which they work and lead businesses. The design of trade policies and negotiation of trade agreements should consider that differential impact on men and women workers and entrepreneurs, so as to ensure that proposed provisions promote women's economic empowerment or, at a minimum, do not widen existing gender gaps. The availability of gender-disaggregated data and the conduct of a prior gender impact assessment will be instrumental in achieving that objective. In particular :

- The fact that women tend to work more in services professions and that women-owned and women-led businesses are also more likely to be in services, should be kept in view. Removing and streamlining restrictions to trade in services can increase market access and allow firms in these sectors to benefit from economies of scale.

- Ensuring that trade costs are lowered for all exporting services firms may be a challenge, since the majority of the gains from trade go to services firms that export through mode 3 , commercial presence abroad, which assumes a size threshold higher than that attained by many womenled firms. In the longer term, if barriers to services trade are reduced, however, new business models may emerge to enable services delivery that does not require the commercial presence of a foreign affiliate.

- Have efforts been made to further liberalise and open up trade in sectors of particular importance to more vulnerable groups, where women are over-represented? Trade liberalisation in sectors that have generally been subject to higher trade barriers such as food and agriculture would increase the purchasing power of such groups. Moreover, staple foods are often more heavily taxed at the border and are more difficult to substitute in household consumption baskets.

- Do tariffs remain on goods destined to women? While no evidence was found of 'regulatory discrimination' in the OECD area in terms of higher tariffs on goods destined to women, effective tariff rates on one product solely destined for women and girls (tampons and sanitary pads, which share a product classification with diapers) are highest in North America and Oceania. These tariffs will impact women and girls, and families with very young children by raising consumer prices on goods that are of first necessity to those destined to buy them, even if they are a very small item in overall expenditure.

\section{Non-tariff measures}

- Are trade policy reforms and trade agreements' negotiations focussing on measures that support the internationalisation of women-led businesses? The suite of trade policies that support exportoriented women entrepreneurs overlaps strongly with policies to support MSME internationalisation. High trade barriers - non-tariff measures, overly cumbersome administrative procedures, inefficient trade infrastructure, lack of transparency regarding process, in addition to tariffs -will affect both women and men entrepreneurs. However, as the removal of these barriers is expected to benefit small businesses even more than large ones, they are bound to be 
particularly profitable to women-led businesses, given their smaller size, lack of experience and shallower networks. In particular:

- Is there appropriate focus on increasing the transparency of regulations and improving the dialogue with the private sector? Greater transparency in regulations and trade facilitating measures that improve MSME or women-led firms' access to trade-related information and their ability to provide feedback on proposed regulations and practices, will reduce their fixed costs and increase their propensity to trade.

- Is there appropriate focus on trade facilitating reforms to reduce fees and charges and simplify and automate procedures applied at the border? Such reform will decrease firms' variable costs thereby enabling MSMEs and women-led firms them to trade more. The automation of the border process can be particularly important for women-led MSMEs, not only because it reduces the costs of processing documentation, but also because by dematerialising formalities it shelters women entrepreneurs from potential harassment and discrimination.

- Are there proactive policies to help women entrepreneurs overcome obstacles in accessing credit and finance, including by providing tools and incentives to financial institutions, improving the business environment for trade and promoting alternative methods for checking credit-worthiness? This is perhaps the most obvious barrier to women's entrepreneurship and to their capacity to grow their business and expand into international trade. Women entrepreneurs request less financing than men and receive a smaller share of what they request, through banks and credit agencies as well as VC financing and angel investing. Many women entrepreneurs therefore start their businesses with very little capital which makes it less likely that they are competitive, that they can engage in global value chains, and that their businesses survive. An interesting model for overcoming access to finance hurdles is the Banking on Women Global Trade Finance Program (BOW-GTFP), launched by the International Finance Corporation (IFC) in partnership with the Goldman Sachs 10000 Women initiative ${ }^{106}$. The BOW-GTFP seeks to incentivize IFC's network of 285 banks in 85 countries to increase trade finance to women importers and exporters; provide tools and incentives for those banks to track business with women-owned SME entrepreneurs (WSMEs), including blended finance in some cases; and generate data and research that will help governments, financial institutions and others to improve the business environment for trade and increase financial solutions for women. Another approach in countries where men traditionally own the land or the house, excluding women from access to finance, is to replace the standard requirement of requesting collateral for loans by other methods to creditcheck an individual, such as issuing loans based on cash flow, savings group history, mobile phone transaction history or a track record of enterprise performance ${ }^{107}$.

- Are there initiatives to promote digital solutions in support of women's entrepreneurship? Some of the barriers to trade and the unconscious bias that women face to starting and growing their businesses can be partially alleviated or reduced by the digital transformation. Evidence suggests that women entrepreneurs engage at least as much as men online and that there is somewhat less gender discrimination in e-commerce. Greater access to information online can somewhat replace women's shallower networks. More generally, digitalisation benefits smaller businesses even more than larger ones. However, there are downsides for women including online abuse, and few women entrepreneurs in the high-risk, high-growth areas of IT and engineering.

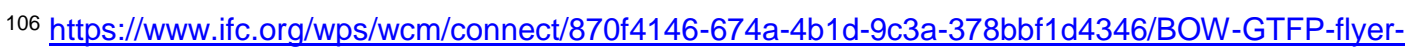
06.pdf?MOD=AJPERES\&CVID=mKP-xox.

107 See https://www.weforum.org/agenda/2019/06/women-finance-least-developed-countries-collateral/. 
- Are there initiatives to combat online harassment? Online harassment is common and the worst forms generally target women, impeding them from accessing their potential. Such initiatives will need to include leaders of online platforms.

- Is there affirmative action in the area of government procurement? Such action may provide a powerful tool to boost women's economic empowerment. Some countries target specific types of businesses in public procurement contracts; others prohibit discrimination on the basis of gender. In the United States, for example, $5 \%$ of government contracts are supposed to be awarded to women-led firms. In Switzerland, preference is given in procurement contracts to firms practicing equal pay.

- Are there efforts to remove unnecessary administrative burdens at the border? These could also significantly boost consumers' purchasing power. Lowering undue trade restrictions on goods and services could bring substantial gains for consumers, in particular those in lower income categories where women are disproportionately represented. It should be kept in mind, however, that trade is only one part of the consumption story: about $40 \%$ of household expenditure is in non-tradables such as housing and will therefore not be directly affected by changes in border protection.

- Are gender considerations incorporated in competition policy? The extent to which lower trade barriers will be passed onto consumers will depend on domestic economic structures, in particular competition and countries' location within global value chains and production networks. In some cases, it may be warranted for competition authorities to focus more on markets that form a larger share of women's expenditure, and to consider basing investigations on different gender-defined markets where price differences are identified, and a market definition assessment is undertaken ${ }^{108}$.

- Are there efforts to mainstream gender provisions in PTA thematic chapters? This could help ensure that PTAs pay proper attention to gender considerations in all of the above areas. In addition to provisions currently found in labour, SME or sustainable development chapters, gender-related provisions in the areas of government procurement, investment, TBT, SPS, IPR or digital trade could foster more concrete policy responses to the advantage of women's economic empowerment.

\section{Export and entrepreneurship promotion}

- Do export promotion agencies provide support to women entrepreneurs in accessing international markets? Assisting women in overcoming hurdles, facilitating their contacts and making information about exporting fully transparent and available can increase their capacity to export. The provision of training on business and financial management to women entrepreneurs, as undertaken by export promotion agencies in some countries, can also be a significant empowering factor. Women entrepreneurs' engagement on international markets is strongly impacted by lesser flexibility in their ability to travel and engage with far away clients; fewer networks and less experience in entrepreneurship, which means they experience more difficulties navigating foreign regulations; and less access to finance which means they cannot necessarily finance the added delays in payment that usually accompany selling to foreign clients. Export promotion agencies can bring support in all these areas.

- Are there efforts to incorporate trade-facilitating policies to support women entrepreneurs in preferential trade agreements under negotiation? The model of existing PTAs setting up trade missions to provide small business owners and entrepreneurs contacts and financial support is a good place to start, but such missions could be more gender-sensitive, e.g. by ensuring that women business owners are well represented or targeting women-owned businesses when allocating

108 https://oecdonthelevel.com/2018/03/02/whats-gender-got-to-do-with-competition-policy/ 
grants and low interest loans that aim to help MSMEs export. Some existing trade missions are women-only although there are differing views about such lack of diversity, which can appear to foster a 'ghettoisation' of women-led firms.

- Are there other initiatives to bridge the gap in women's networks by providing information and contacts for women entrepreneurs aiming to trade or to increase their international activity? The Women in Trade organisation holds networking activities for export-oriented women entrepreneurs to grow their professional networks and obtain information crucial to trade. Some countries use the platforms afforded by PTAs to increase transparency regarding procedures to export and opportunities that those PTAs provide. These initiatives, if done well, can particularly support small businesses, among them women-led businesses.

- Incubators that are supportive of women entrepreneurs may also be a tool for women's economic empowerment. Although business incubators dedicated to women account for fewer than $3 \%$ of incubators globally, some evidence suggests they are more effective than mainstream incubators that rely on networks and selection panels that are dominated by men.

\section{Domestic policies}

- Trade policies alone will not bridge the gender gaps that in some areas and some regions are vast. Trade policies can only be part of a comprehensive strategy to increase women's economic empowerment and open the way for increasing national incomes through greater use of women's skills through the labour market. It is important to identify any required interventions in the realm of domestic policies in order to ensure that women are able to reap the gains from trade. The main domestic policy areas where action is needed to increase women's ability to compete internationally are listed in Annex E. 


\section{OECD TRADE POLICY PAPERS}

This report was declassified by the OECD Working Party of the Trade Committee in March 2021 and was prepared for publication by the OECD Secretariat.

This report, as well as any data and any map included herein, are without prejudice to the status of or sovereignty over any territory, to the delimitation of international frontiers and boundaries and to the name of any territory, city or area.

The statistical data for Israel are supplied by and under the responsibility of the relevant Israeli authorities. The use of such data by the OECD is without prejudice to the status of the Golan Heights, East Jerusalem and Israeli settlements in the West Bank under the terms of international law.

Comments are welcome and can be sent to tad.contact@oecd.org. 